\title{
GEOLOGIC MAP OF PORTIONS OF THE LIVENGOOD B-3, B-4, C-3, AND C-4 QUADRANGLES, TOLOVANA MINING DISTRICT, ALASKA
}

Evan Twelker, Jennifer E. Athey, Rainer J. Newberry, Gerald G. Griesel, David J. Szumigala, Lawrence K. Freeman, Brent A. Elliott, Melanie B. Werdon, and De Anne S.P. Stevens

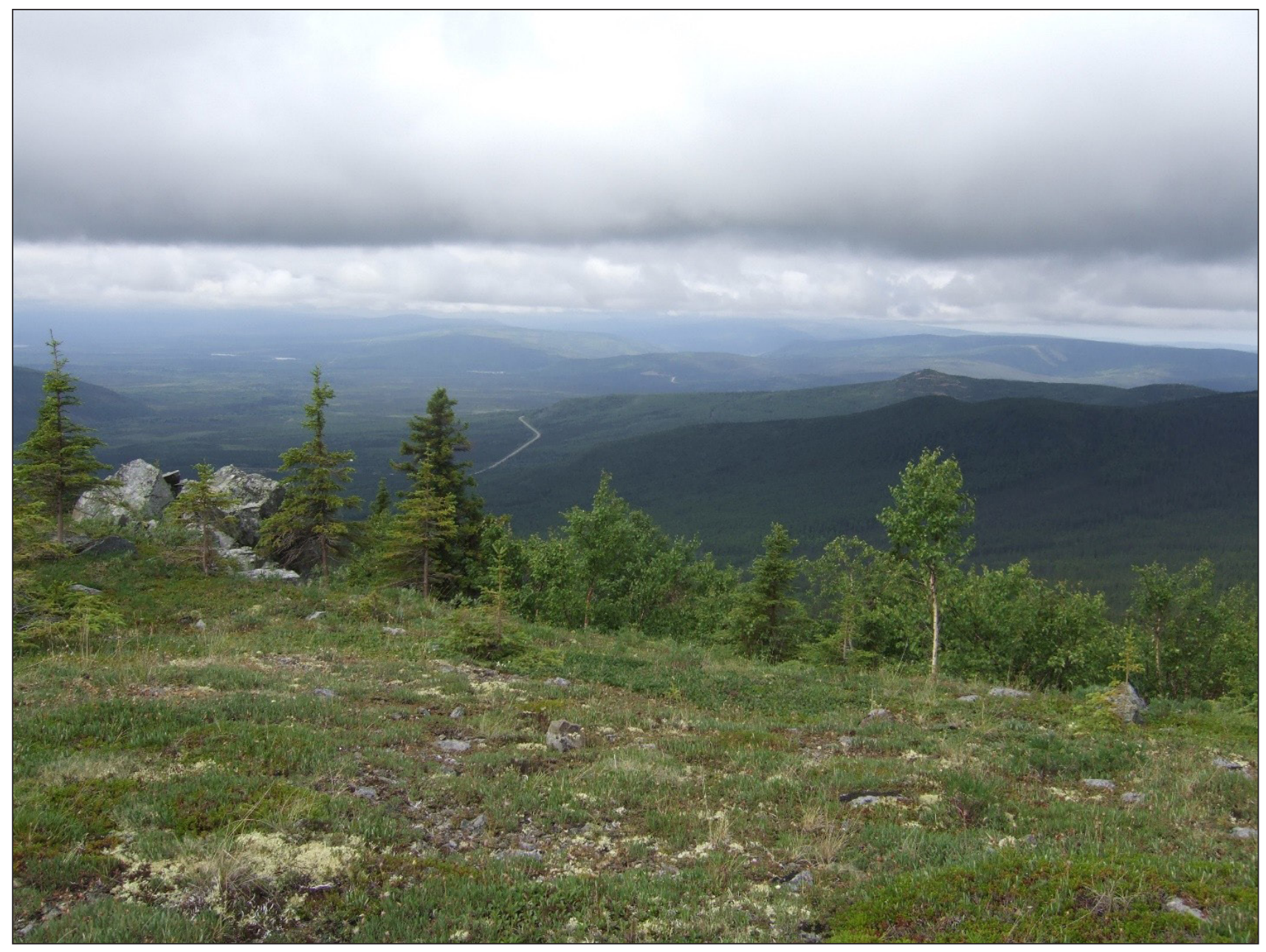

Overview photo, looking west across the central map area. In the distance from left to right are the Tolovana River, the Elliott Highway, Money Knob, and Amy Dome. Photo by L.K. Freeman.

\section{Published by}

STATE OF ALASKA

DEPARTMENT OF NATURAL RESOURCES

DIVISION OF GEOLOGICAL \& GEOPHYSICAL SURVEYS

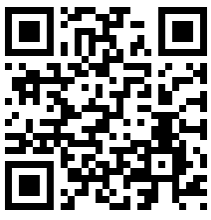





\section{GEOLOGIC MAP OF PORTIONS OF THE \\ LIVENGOOD B-3, B-4, C-3, AND C-4 QUADRANGLES, TOLOVANA MINING DISTRICT, ALASKA}

Evan Twelker, Jennifer E. Athey, Rainer J. Newberry, Gerald G. Griesel, David J. Szumigala, Lawrence K. Freeman, Brent A. Elliott, Melanie B. Werdon, and De Anne S.P. Stevens

Report of Investigation 2016-5

State of Alaska

Department of Natural Resources

Division of Geological \& Geophysical Surveys 


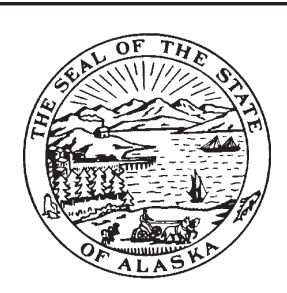

STATE OF ALASKA

Bill Walker, Governor

\section{DEPARTMENT OF NATURAL RESOURCES}

Andy Mack, Commissioner

\section{DIVISION OF GEOLOGICAL \& GEOPHYSICAL SURVEYS}

Steve Masterman, State Geologist and Director

Publications produced by the Division of Geological \& Geophysical Surveys (DGGS) are available for free download from the DGGS website (dggs.alaska.gov). Publications on hard-copy or digital media can be examined or purchased in the Fairbanks office:

\section{Alaska Division of Geological \& Geophysical Surveys 3354 College Rd., Fairbanks, Alaska 99709-3707 \\ Phone: (907) 451-5010 Fax (907) 451-5050 \\ dggspubs@alaska.gov \\ dggs.alaska.gov}

Publications are also available at these libraries:

Alaska State Library

State Office Building, 8th Floor

333 Willoughby Avenue

Juneau, Alaska 99811-0571
Alaska Resource Library \& Information Services (ARLIS)

3150 C Street, Suite 100

Anchorage, Alaska 99503-3982 


\section{CONTENTS}

INTRODUCTION

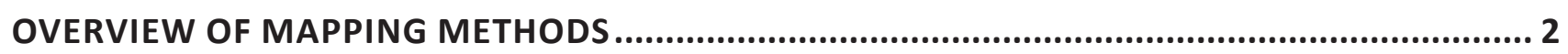

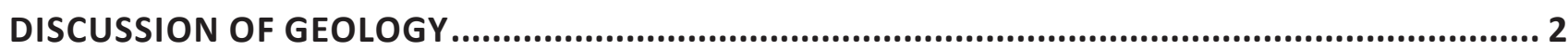

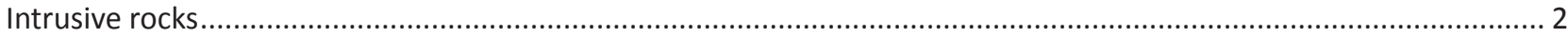

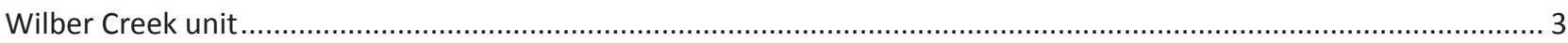

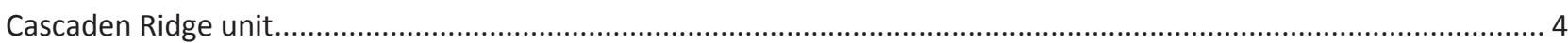

Amy Creek unit .

Lost Creek unit .

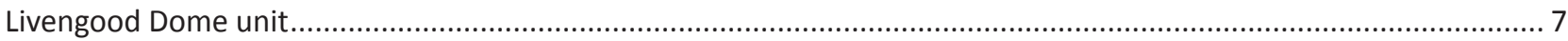

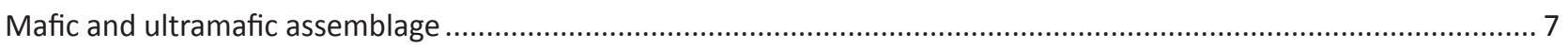

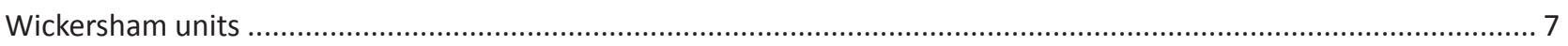

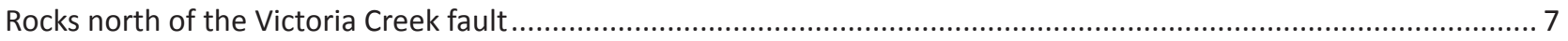

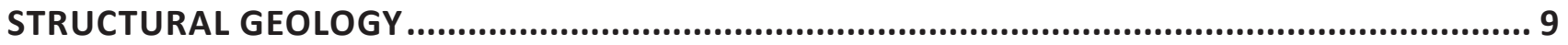

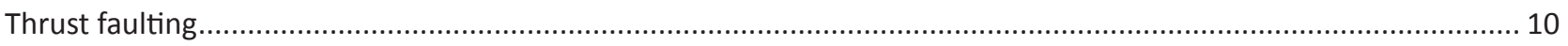

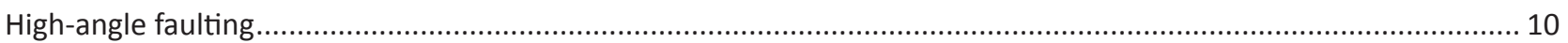

ECONOMIC GEOLOGY ...................................................................................... 10

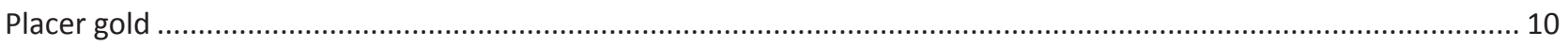

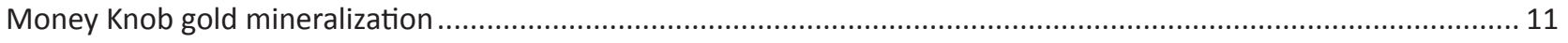

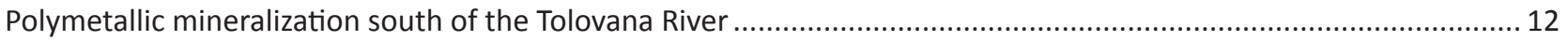

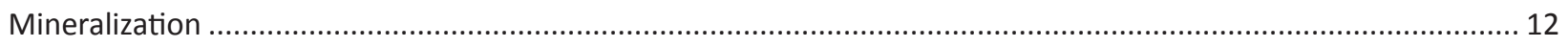

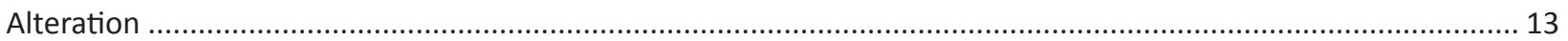

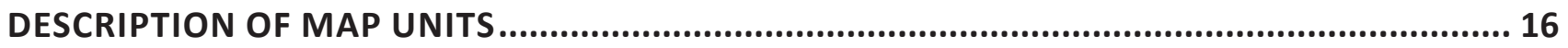

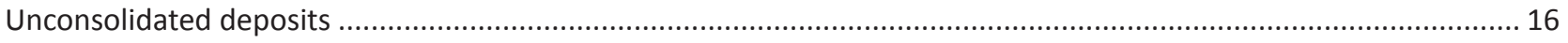

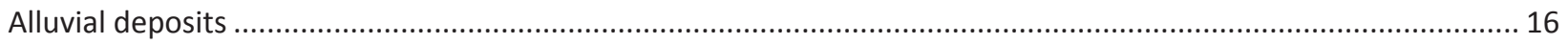

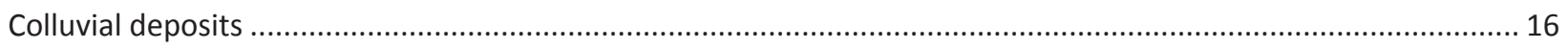

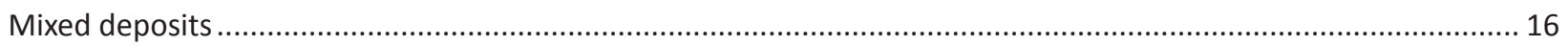

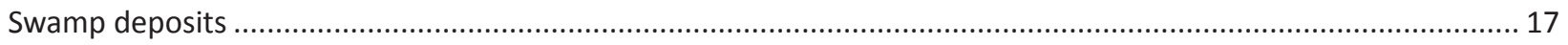

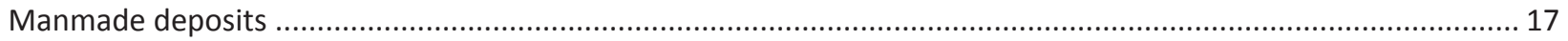

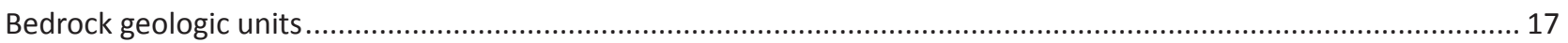

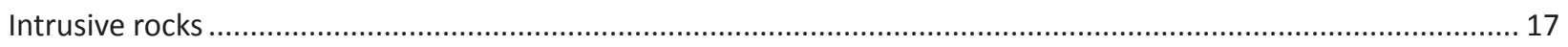

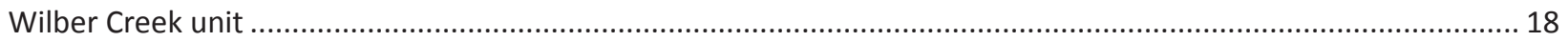

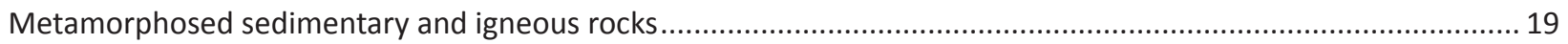

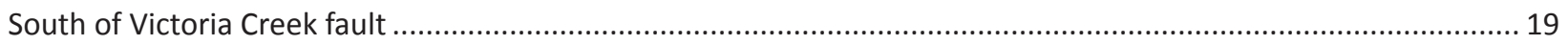

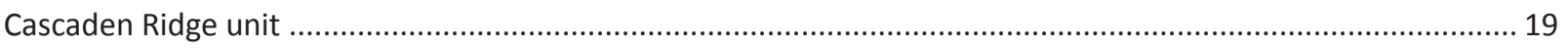

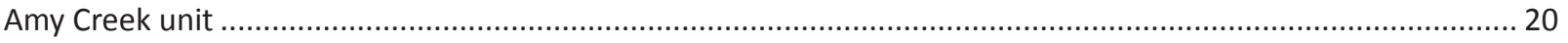

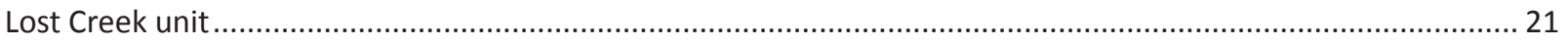

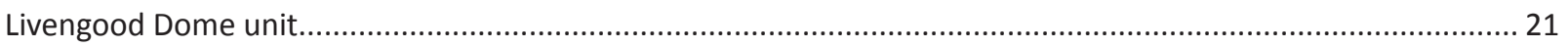

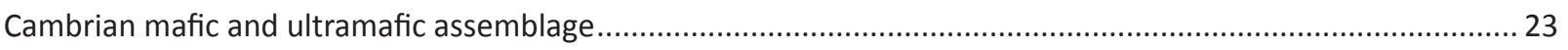

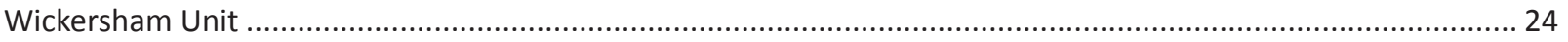

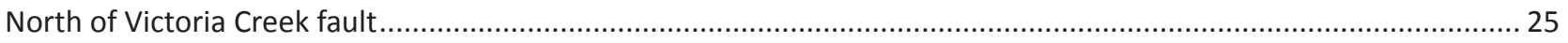

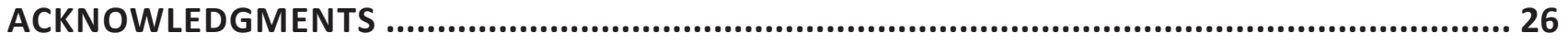

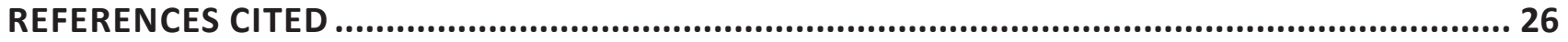




\section{FIGURES}

Figure 1. Location of the map area and Livengood geophysical survey .......................................................... 1

2. MORB-normalized spider diagram for trace-element profiles of felsic igneous intrusions in the map area...... 3

3. Stereonet plots for bedding measurements in major structural domains ............................................. 9

4. Bivariate geochemical plots of mineralization at Money Knob and Hill 1835 ............................................. 13

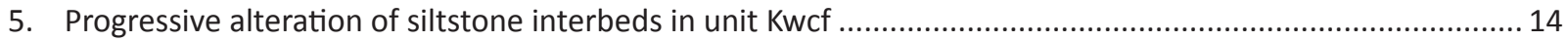

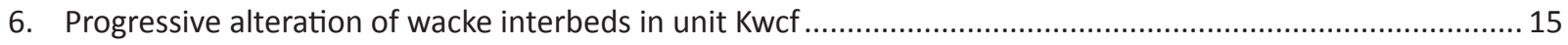

\section{TABLES}

Table 1. Macrofossil and microfossil identifications in the Livengood area, Alaska............................................... 5

2. Summary table of radiometric age dates in the map area ................................................................. 6

3. Preliminary stratigraphic correlations in the Livengood Quadrangle, Alaska ............................................. 8

\section{APPENDICES}

APPENDIX A ${ }^{40} \mathrm{Ar} /{ }^{39} \mathrm{Ar}$ ANALYSIS OF SAMPLE 2010MBW016B-BIOTITE ............................ 31

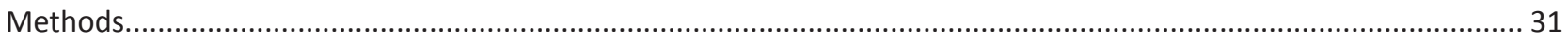

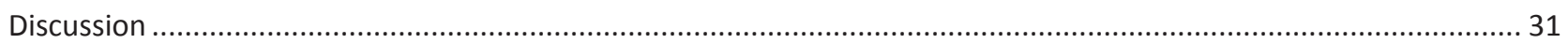

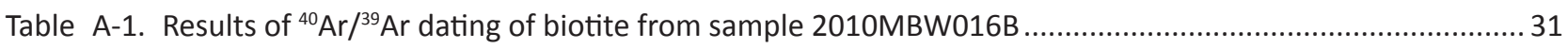

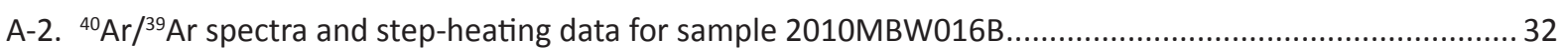

APPENDIX B DIRECT X-RAY FLUORESCENCE (XRF) METHODOLOGY ...................................... 33

Table B-1. Direct X-ray fluorescence (XRF) data collected on felsic igneous rocks in the study area.........................34

APPENDIX C DETRITAL ZIRCON ANALYSIS OF SAMPLE 10Z222A ......................................... 35

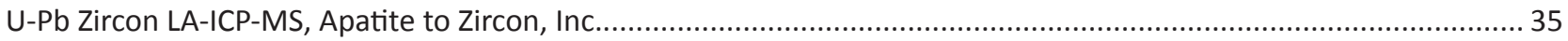

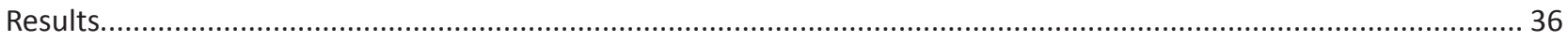

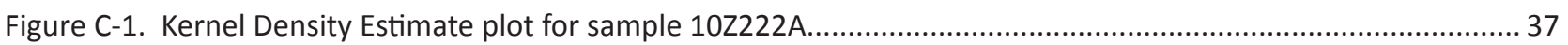

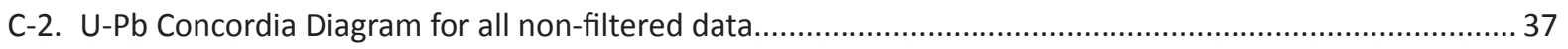

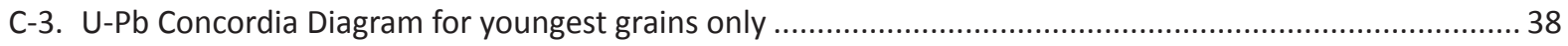

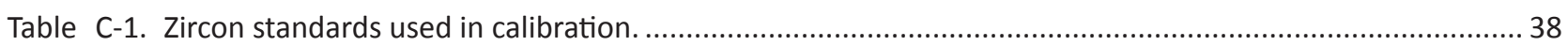

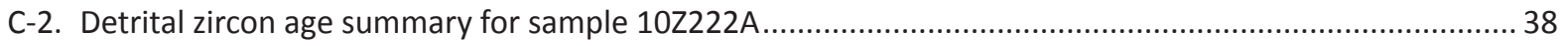

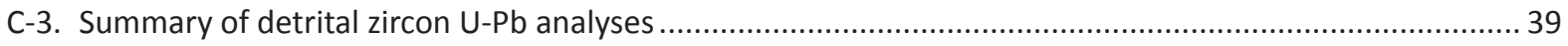




\section{GEOLOGIC MAP OF PORTIONS OF THE LIVENGOOD B-3, B-4, C-3, AND C-4 QUADRANGLES, TOLOVANA MINING DISTRICT, ALASKA}

Evan Twelker ${ }^{1}$, Jennifer E. Athey ${ }^{1}$, Rainer J. Newberry², Gerald G. Griesel ${ }^{3}$, David J. Szumigala ${ }^{1}$, Lawrence K. Freeman ${ }^{1}$, Brett A. Elliott ${ }^{4}$, Melanie B. Werdon ${ }^{1}$, and De Anne S.P. Stevens ${ }^{1}$

\section{INTRODUCTION}

This report accompanies the geologic map of portions of the Livengood B-3, B-4, C-3, and C-4 quadrangles. The Livengood area is a historically productive placer mining area approximately 80 road miles north of Fairbanks, Alaska (fig. 1). It has produced approximately 542,000 ounces of gold since 1914 (Athey and others, 2014). Modern exploration for lode gold mineralization began in 1970 and so far resulted in the discovery and delineation of a 15.7-millionounce intrusion-related gold measured and indicated resource by International Tower Hill Mines, Ltd. (ITH) (Samuel Engineering, 2013). At the date of this report, work continues at both Money Knob and at Freegold Ventures' Shorty Creek exploration project.

This report synthesizes recently collected and previously published agency and industry geologic data in a 1:50,000-scale comprehensive geologic map to build a better understanding of the geology and mineral-resource potential of the Livengood area. It expands and updates the Alaska Division of Geological \& Geophysical Surveys (DGGS) Preliminary Interpretive Report (PIR) 2004-3 (Athey and

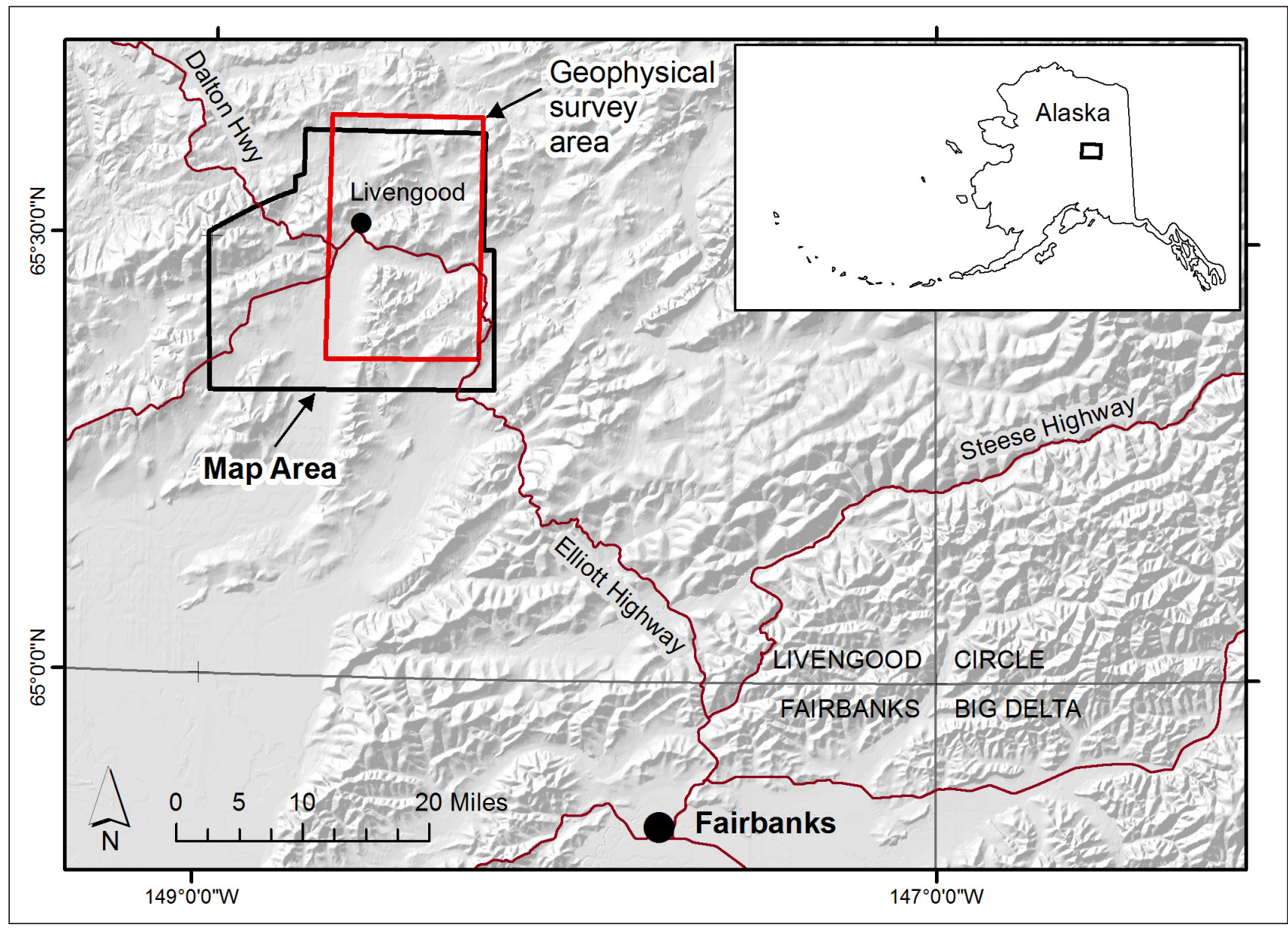

Figure 1. Location of the map area and Livengood geophysical survey (Burns and others, 2015).

${ }^{1}$ Alaska Division of Geological \& Geophysical Surveys, 3354 College Road, Fairbanks, AK 99709-3707; evan.twelker@alaska.gov ${ }^{2}$ University of Alaska Fairbanks, Department of Geosciences - Geology, Geophysics and Geography, P.O. Box 755780, Fairbanks, AK 99775-5780 ${ }^{3}$ Alaska Division of Geological \& Geophysical Surveys, 3354 College Road, Fairbanks, AK 99709-3707; now 114 Rolling Hills Drive, Elko, NV 89801

${ }^{4}$ Alaska Division of Geological \& Geophysical Surveys, 3354 College Road, Fairbanks, AK 99709-3707; now at University of Texas at Austin, Bureau of Economic Geology, Jackson School of Geosciences, P.O. Box X, Austin, TX 78713-8924 
others, 2004b) with the addition of new DGGS mapping and drillhole data from ITH, and integrates previously published DGGS surficial geology from Report of Investigation (RI) 84-6 (Waythomas and others, 1984) and RI 2013-2 (Reger and Burns, 2013).

\section{OVERVIEW OF MAPPING METHODS}

This geologic map and report draws on work completed by DGGS in 1982, 2003, and 2010, as well as work by ITH. DGGS mapping in 2003 focused on the Livengood southeast C-4 and southwest C-3 quadrangles and was published as PIR 2004-3 and RI 2013-2. The 2003 project included approximately 90 person-days of fieldwork, and the 2010 DGGS program consisted of approximately 100 person-days of bedrock geologic mapping fieldwork spent mainly in the north half of the Livengood B-4 and the northwest B-3 quadrangles. Together, the 2003 and 2010 programs combine for 2,444 handheld-GPS-located geologic mapping stations. Outcrop map data from the 1982 DGGS field projects (Albanese, 1983 [RI 83-3]; Robinson, 1983 [RI 83-4]; Smith, 1983 [RI 83-5]; Bundtzen, 1983 [RI 83-6]) were also incorporated in field planning and final geologic interpretation.

The map area covers the majority of the 229-squaremile Livengood airborne magnetic and electromagnetic geophysical survey (Burns and others, 2015). This survey greatly facilitated our extrapolation of contacts and faults through areas of vegetative and Quaternary cover. To aid in interpretation of the geophysical surveys, field crews collected handheld magnetic susceptibility measurements from outcrop and float during the course of mapping. Two to 10 individual measurements were taken at each station using Terraplus KT 5, 6, and 9 handheld magnetic susceptibility meters. Measurement surfaces and degree of oxidation varied, and no effort was made to assess or measure the effects of remnant magnetization; therefore, the data should be considered semi-quantitative. Mean values and ranges are reported by map unit in the unit descriptions section of this report.

\section{DISCUSSION OF GEOLOGY}

\section{INTRUSIVE ROCKS}

Numerous small exposures of felsic igneous rocks intrude the Cascaden Ridge, Wilber Creek, and Cambrian maficultramafic units in the southern half of the map area. Many of these exposures are altered or weathered such that the lithology cannot be readily identified; however, four basic types have been defined from least-altered samples, and immobile trace-element geochemical, textural, and mineralogical characteristics have been used to identify some of the less fresh samples. Geochemical data, obtained by laboratory-grade XRF of polished rock slabs at the University of Alaska Fairbanks, are included with this report as Appendix B.

The youngest intrusions in the map area are $\sim 68$ Ma plagioclase-quartz-K-feldspar-biotite porphyry dikes and sills of the Shorty Creek intrusive suite (unit Ksc). These are characteristically subalkaline and granitic in composition; quartz phenocrysts, less subject to weathering and alteration, are commonly distinguishable in hand sample. These properties were also used to assign altered or weathered felsic exposures to unit Ksc when no geochemistry was available. The geochemical profile for this sample is illustrated in figure 2 . Many of the "unknown" samples from the Shorty Creek and Wilber Creek areas share this geochemical profile, which is less evolved overall (has lower values of the incompatible elements $\mathrm{Th}, \mathrm{Nb}, \mathrm{Zr}$, and $\mathrm{Y}$ ) and lacks the pronounced $\mathrm{Ti}$ depletion seen in units Kmk, Kcrp, and Dcv.

Porphyritic biotite-K-feldspar syenite to quartz monzonite dikes and sills of the $\sim 92$ Ma Money Knob intrusive suite (unit Kmk) are characteristically altered and closely associated with gold mineralization at the Money Knob deposit. The trace-element geochemical profile for this unit (fig. 2) shows pronounced Ti depletion relative to the other elements and contrasts significantly with that of the younger Shorty Creek intrusive suite. While the altered syenite to quartz monzonite of the Cascaden Ridge pluton (unit Kcrp) is slightly more evolved (uniformly higher quantities of incompatible elements $\mathrm{Th}, \mathrm{Nb}, \mathrm{Zr}$, and $\mathrm{Y}$ ) than unit $\mathrm{Kmk}$, the immobile trace-element profiles of these two alkaline intrusive units are similar. For this reason, unit Kcrp is tentatively assigned an early Late Cretaceous age. Our attempt to date this unit using LA-ICP-MS U-Pb techniques failed due to poor zircon quality.

Devonian peralkaline rhyolite tuffs and flow breccias (unit Dcv) that were previously mapped as the Cretaceous(?) Ruth Creek and Olive Creek plutons of Athey and others (2004b) have subsequently been shown to be a stratiform volcanic unit. Core drilling by ITH revealed clearly recognizable volcanic textures and defined the geometry of the unit as a conformable(?) layer in the Cascaden Ridge unit stratigraphy. The unique immobile trace-element profile associated with this unit (fig. 2) enabled us to identify it on Cascaden Ridge at the western edge of the map area. Similarly, the extremely high $\mathrm{Zr}$ and $\mathrm{Nb}$ concentrations of intrusive-textured rocks exposed between Olive Creek and Cache Creek led to our conclusion that these rocks, unit $\mathrm{Di}$, represent a coeval intrusive body related to unit Dcv peralkaline volcanic rocks. The age of the volcanics and, by extension, the unit Di intrusives is known only from fossil ages established for the Cascaden Ridge sedimentary units. 


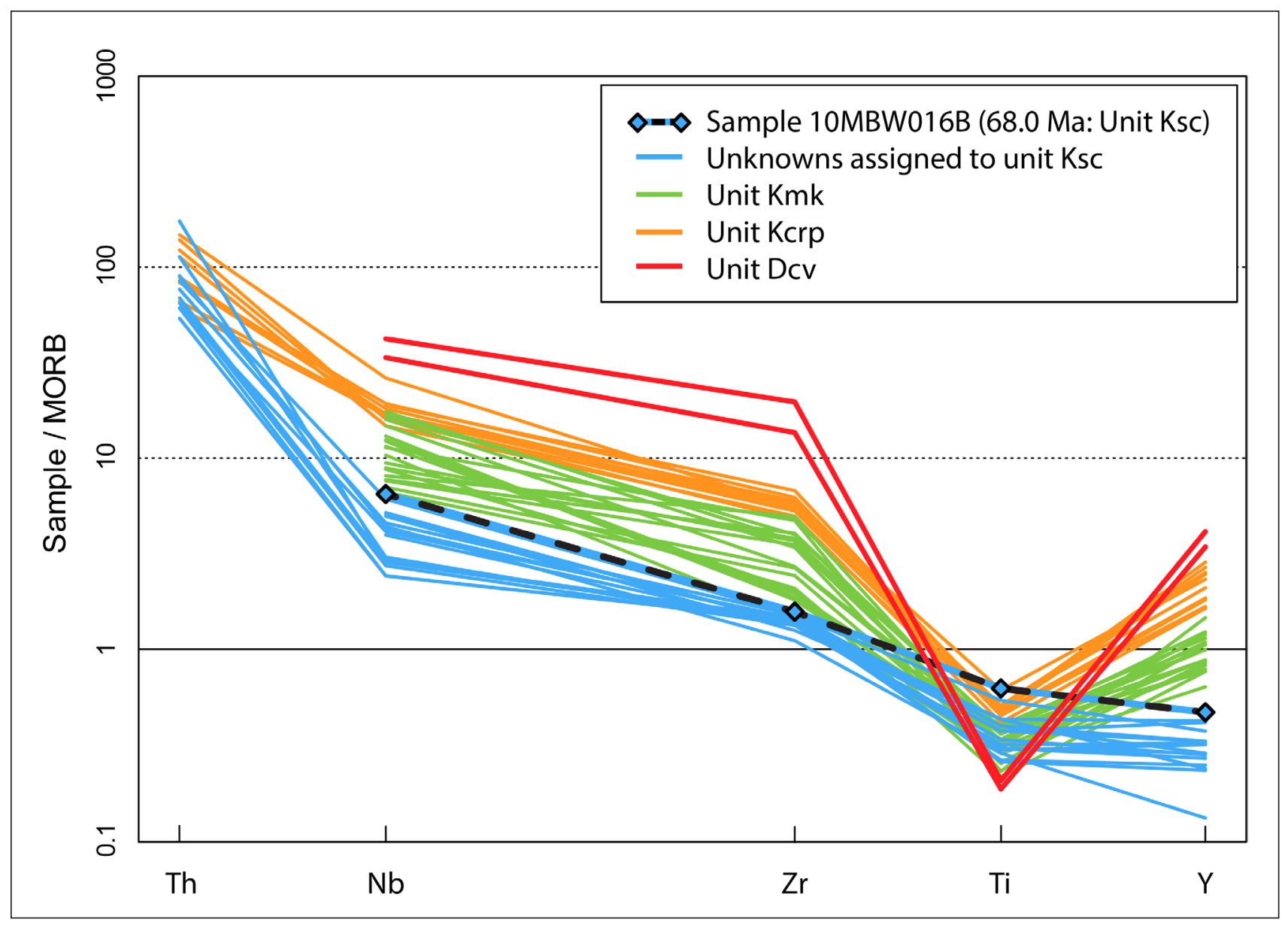

Figure 2. MORB-normalized spider diagram after Pearce (1996), illustrating the trace-element geochemical profiles of some of the felsic intrusions sampled in the map area. Data are from direct XRF analysis of polished rock slabs performed at the University of Alaska Fairbanks (Appendix B).

\section{WILBER CREEK UNIT}

The Lower Cretaceous (Albian) Wilber Creek unit of Weber and others (1994) is a fault-bounded package of clastic sedimentary rocks ranging in grain size from shale to conglomerate; on this map it is subdivided into three map units: interbedded turbidites ranging from shale to coarse sandstone (Kwcf) $>>$ shale and siltstone (Kwcs) > conglomerate (Kwcc). Exposures in the map area are very limited and therefore these units represent lithologic units rather than specific stratigraphic units.

These rocks were assigned to the Manley terrane by Silberling and others (1994) on account of faulted contacts and lack of a clear depositional or provenance relationships to the underlying Paleozoic terranes. Gergen and others (1988) concluded, based on point-count analyses of clast lithologies of four samples, that the basin had both magmatic arc sources and craton interior sources. The population of lithic clasts observed in the wacke is not consistent with a source in the adjacent Livengood or White Mountains terranes. Gergen and others (1988) tentatively ascribe the interbedded nature of the two provenances to sedimentary sources on opposite sides of the basin.
The Wilber Creek conglomerate (unit Kwcc) contains clasts of felsic to intermediate igneous rocks, quartzites, sandstones, and minor foliated metamorphic rocks averaging $2 \mathrm{~cm}$. Many of these clasts are large enough $(2.7 \mathrm{~cm}$ diameter $)$ for direct XRF analysis as described in Appendix B. Of 46 clasts analyzed for this study, 20 are igneous rocks based on textural and major oxide concentrations and ratios, and most of these are felsic volcanic lithologies. The remainder are mostly sedimentary, including chert and sandstone, and a few are foliated metamorphic rocks. The igneous rocks do not have major- or trace-element characteristics of the peralkaline Cascaden Ridge volcanics (Dcv) or the metamafic rocks of Amy Creek or Cambrian mafic-ultramafic assemblages. The sandstone clasts are compositionally distinct from sandstones of the Cascaden Ridge units, which have a distinctive elevated $\mathrm{Cr}$ concentration. Therefore, we concur with Gergen and others (1988) that the Wilber Creek unit has a source that is outside of the immediate map area.

Weber and others (1992) assigned the Wilber Creek unit to the Lower Cretaceous (Albian) based on the ammonite Paragastroplites flexicostatus found in the Livengood B-6 Quadrangle. 


\section{CASCADEN RIDGE UNIT}

The Cascaden Ridge unit is a mixed sedimentary (Dc, $\mathrm{Dcl}$, and Dcu) unit consisting of interbedded sandstone, shale, and minor conglomerate, and a locally recognized thin (10 to $75 \mathrm{~m}$ thick) layer of peralkaline rhyolitic volcanic rocks. Previous workers (Weber and others, 1992; Athey and others, 2004b) mapped these rocks as a single clastic sedimentary unit (Dc), but subsequent industry-led drilling and mapping in the Money Knob area led to the subdivision of this unit into lower sediments (Dcl) and upper sediments (Dcu) separated by peralkaline rhyolitic flows and tuffs (Dcv). Weber (oral communication, 2004) suggests a total thickness for this unit of $1,036 \mathrm{~m}$ based on a section located on Cascaden Ridge in the current map area.

A fossil locality in the map area indicates a Middle Devonian age for this unit (Blodgett, 1992; see table 1 and map location F1). Fossils are found in debris flows, and are thought to have been transported contemporaneously with sediments in a wave-based environment (Weber and others, 1985). Blodgett (1992) suggests that the clastic rocks were deposited in a shallow-water basin in the vicinity of local uplift. Point-count analysis of Cascaden Ridge sandstones by Gergen and others (1988) indicates they were derived from local units.

The Devonian Cascaden Ridge unit (Dc) of this map may be facies-equivalent to mid-Devonian limestone and clastic rocks of the Quail unit of Weber and others (1992), located $25 \mathrm{~km}$ to the west, and sedimentary rocks of the Beaver Bend unit and the upper part of the Tolovana limestone, located 25 $\mathrm{km}$ to the southeast (Weber and others, 1992).

\section{AMY CREEK UNIT}

A sequence of interlayered siliceous mudstone and chert (unit IPZZmc), dolostone and limestone (unit IPZZd), and interlayered metabasalt (unit IPZZmb) comprise the Amy Creek unit (unit SZa of Weber and others, 1992). The age of this unit is as young as Silurian, but it is poorly constrained by fossil, radiometric, and relative stratigraphic ages.

The siltstone (unit $\mathbb{P} Z \mathbf{Z} \mathbf{m c}$ ) contains sponge spicules in a 3-mm-thick spicule-rich layer, suggesting a maximum age of latest Proterozoic for the unit (map location F14; table 1). The marked absence of macrofossils and conodonts in IPZZd could be due to extensive dolomitization and silicification; however, the presence of algal chips and lack of shelly fauna is also compatible with a late Proterozoic age as inferred by previous workers (Weber and others, 1992; Weber and others, 1994; Reifenstuhl and others, 1998; Clough and Goldhammer, 2000). The overlying Devonian sedimentary unit (Dc) contains clasts of dark-gray-black mudstone and chert that are interpreted to be eroded from the Amy Creek mudstone and chert unit (IPZZmc); hence a lower Paleozoic (pre-Devonian) to uppermost Proterozoic age is assigned to this unit.

Two miles west of our map area, outcrops of clastic rocks containing gabbroic and carbonate cobbles yield late Ordovician to earliest Silurian fauna of Siberian affinity (Rigby and others, 2008). These rocks are on strike with the Amy Creek unit and in a similar structural position beneath the Cambrian mafic and ultramafic thrust sheet. Additionally, a detrital zircon sample taken from a rare conglomerate (table 2; map location DZ1) yielded a single peak around 446 Ma, suggesting an early Silurian maximum depositional age (Bradley, written commun., 2013; see Appendix C of this report). It is not certain whether these conglomerates are part of Amy Creek unit or a separate, structurally or unconformably juxtaposed unit that has not been recognized on this map.

A homogeneous layer of dolostone $(\mathbb{P Z Z d})$ lies above a thick section of $\mathbb{I Z Z Z m c}$ and is capped by a mixed layer of predominantly dolostone and lesser siliceous mudstone, chert (IPZZmc), and metabasalt (IPZZmb). The dolomitic portion $(\mathbb{P Z Z} \mathbf{Z})$ of the unit is compatible with a relatively shallow-water depositional environment (probably inner shelf, that is, shallow subtidal to supratidal) built on the lower siliceous mudstone and chert unit (IPZZmc) that represents a moderately deep-water (outer shelf or deeper) environment of deposition (R.B. Blodgett, written commun, 2004). On trace-element discrimination diagrams, the metabasalt (unit IPZZmb) displays within-plate elemental ratios (this study; Athey and others, 2004c), suggesting extrusion of flows and/ or sills in a rift environment. Based on stratigraphy inferred from our mapping and interpretations of geophysical data of Burns and others (2015), we agree with Weber and others' (1992) suggested total thickness of at least 1,158 $\mathrm{m}$ for the Amy Creek unit.

Lithologic equivalents of the lower Paleozoic to upper Proterozoic Amy Creek unit (IPZZd, IPZZmb, IPZZmc) recognized in the current map area are uncertain. One example of a dolostone unit of known late Proterozoic age is the Katakturuk Dolomite of Clough and Goldhammer (2000), approximately $1,000 \mathrm{~km}$ to the north. The Amy Creek dolostone $(\mathbb{P Z Z d})$ is distinguished from the Katakturuk Dolomite by the absence of stromatolites and sedimentary structures and the presence of a $>884-m$-thick section of siliceous mudstone and chert, although these discrepancies could be due to a difference in sedimentary facies. The greenstone unit that underlies the Katakturuk Dolomite has a trace-elementindicated within-plate tectonic signature (Moore, 1987), as does the Amy Creek metabasalt (unit IPZZmb). Alternatively, the Amy Creek unit may be facies-equivalent of the lower(?) sedimentary portion of the Ordovician Fossil Creek unit of the White Mountains (Weber and others, 1992). The alkaline volcanic rocks in the Fossil Creek unit (Weber and others, 1992) $37 \mathrm{~km}$ to the east are also similar in chemical composition to $\mathbb{P} Z \mathbf{Z} \mathrm{mb}$, and both units have a within-plate trace-element-indicated tectonic signature (R.J. Newberry, unpub. data, 2004).

\section{LOST CREEK UNIT}

Silurian limestone (SI) and Silurian clastic sedimentary rocks (Ss) are subdivisions of the Lost Creek unit (SDI) of Weber and others (1992). The limestone contains fauna suggestive of a carbonate platform and is interpreted to have shed debris downslope into a deeper-water clastic environment represented by unit Ss (Blodgett and others, 1988). A 


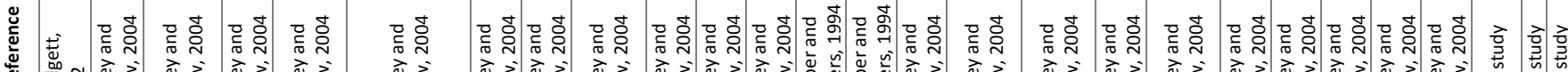

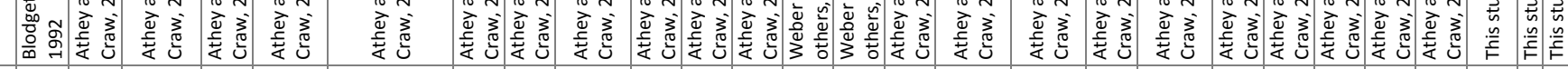

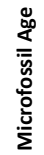

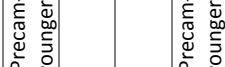

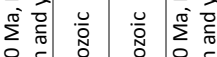

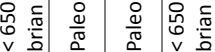

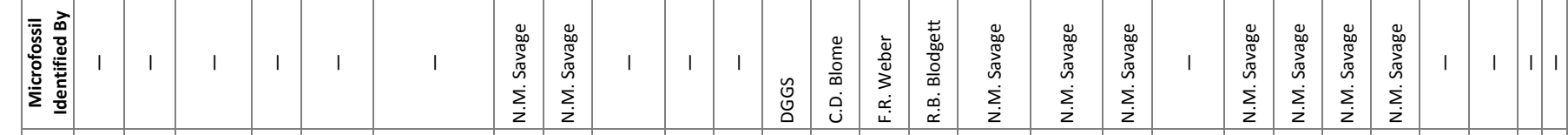

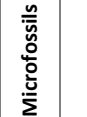

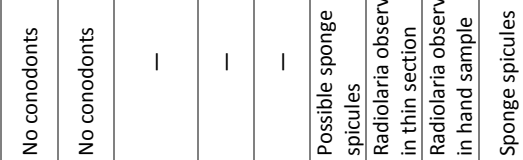

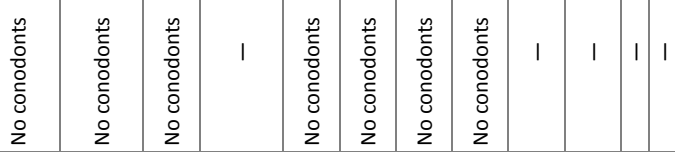

है

10

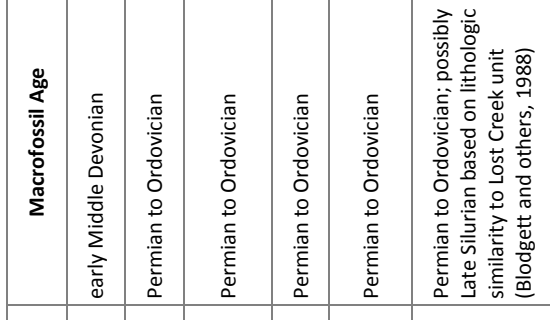

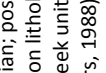

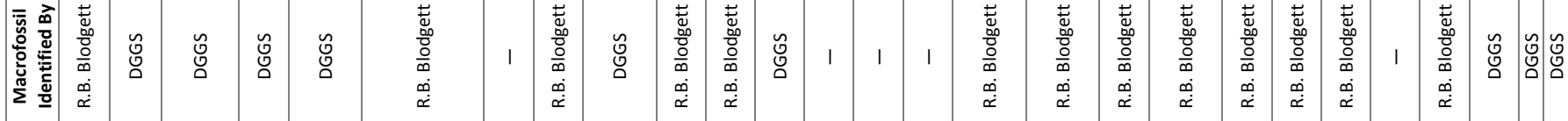

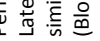

$\frac{5}{2}$
$\frac{5}{5}$
$\frac{5}{5}$

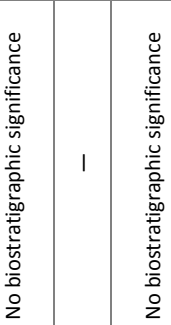

든

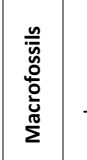

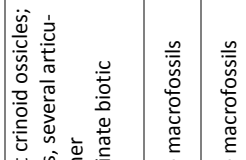

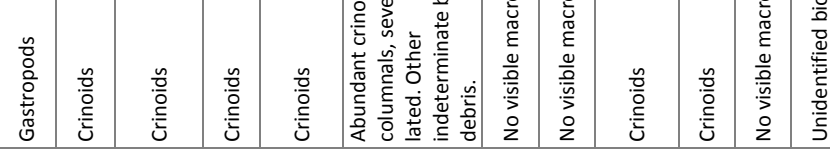

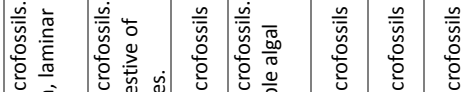

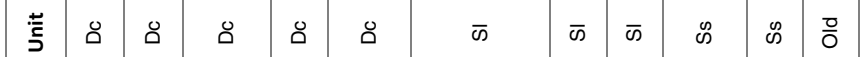

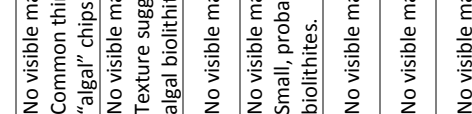

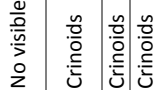

章

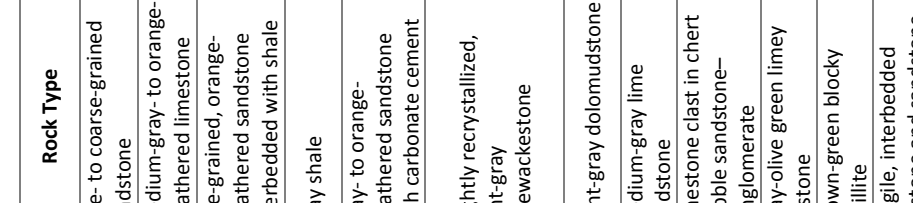

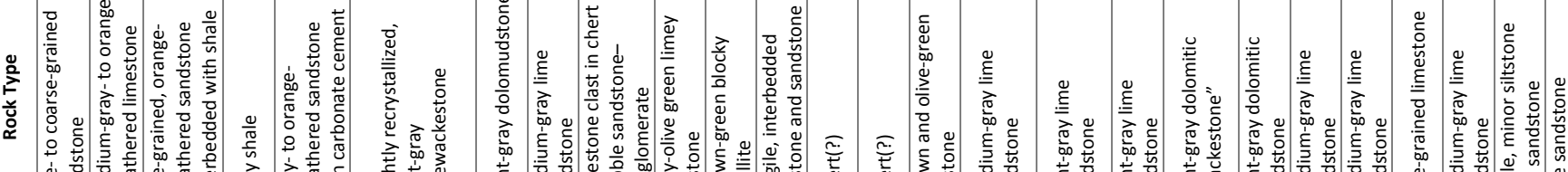

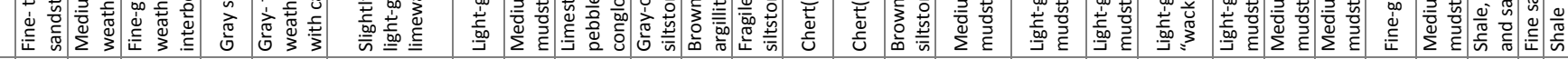

\begin{tabular}{|c|c|c|c|c|c|c|c|c|c|c|c|c|c|c|c|c|c|c|c|c|c|c|c|c|c|}
\hline & 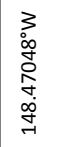 & 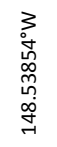 & 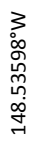 & 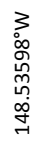 & 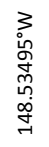 & 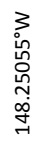 & 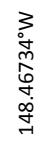 & 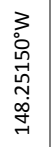 & 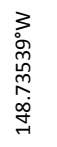 & 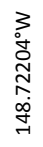 & 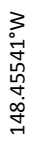 & 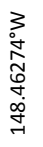 & 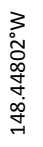 & 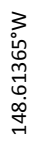 & 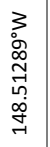 & 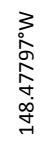 & 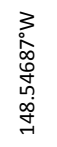 & 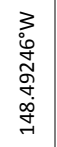 & 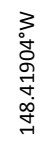 & 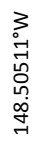 & 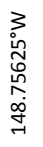 & 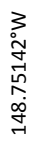 & 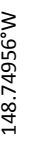 & & \\
\hline & $\begin{array}{l}z \\
0 \\
0 \\
0 \\
\omega \\
\omega \\
\omega \\
\omega\end{array}$ & 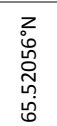 & 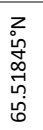 & 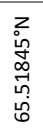 & $\begin{array}{l}z \\
0 \\
0 \\
0 \\
i \\
\omega \\
0\end{array}$ & $\begin{array}{l}\text { o } \\
0 \\
0 \\
0 \\
0 \\
0 \\
0 \\
0\end{array}$ & $\begin{array}{l}z \\
0 \\
0 \\
0 \\
0 \\
0 \\
0\end{array}$ & $\begin{array}{l}z \\
0 \\
\infty \\
0 \\
0 \\
0 \\
0 \\
0\end{array}$ & 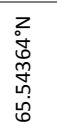 & 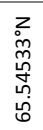 & 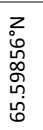 & $\begin{array}{l}z \\
0 \\
0 \\
0 \\
0 \\
0 \\
0 \\
0\end{array}$ & 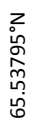 & 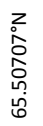 & $\begin{array}{l}z \\
\vdots \\
0 \\
0 \\
0 \\
0 \\
0 \\
0\end{array}$ & 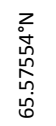 & 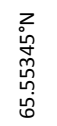 & $\begin{array}{l}z \\
0 \\
0 \\
0 \\
0 \\
\hat{0} \\
0\end{array}$ & 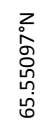 & $\begin{array}{l}\text { zo } \\
0 \\
0 \\
0 \\
0 \\
0 \\
0\end{array}$ & 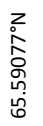 & 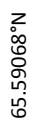 & 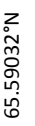 & & 令 \\
\hline
\end{tabular}

कृ

它

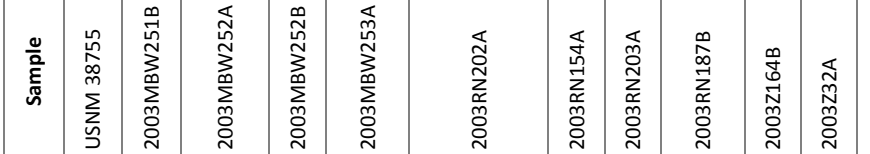

离

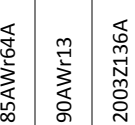

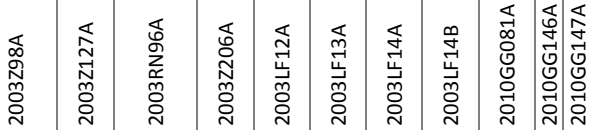

$\frac{10}{8}$

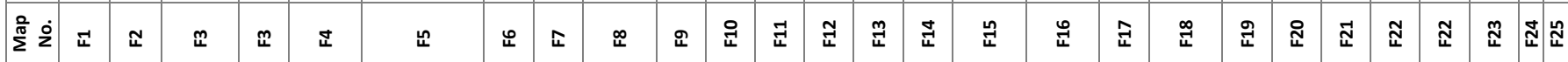




\begin{tabular}{|c|c|c|c|c|c|c|c|c|c|c|}
\hline 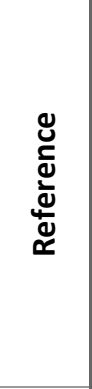 & 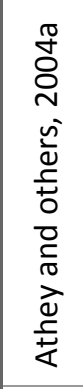 & 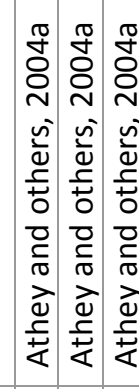 & 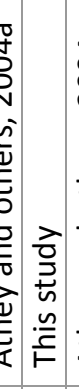 & 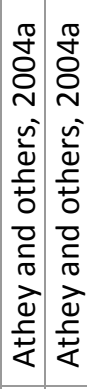 & 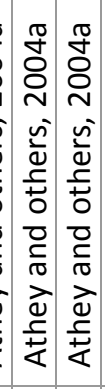 & 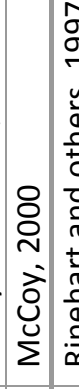 & 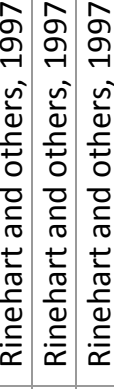 & 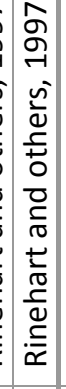 & 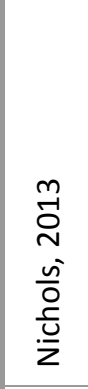 & 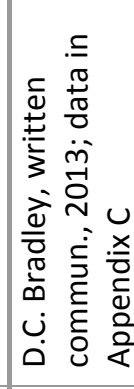 \\
\hline 苋 & $\begin{array}{l}\vec{J} \\
\stackrel{\Xi}{ \pm} \\
\frac{\pi}{\alpha}\end{array}$ & \begin{tabular}{lll}
$\frac{J}{\pi}$ & \multicolumn{2}{c}{} \\
$\frac{\pi}{\mathbb{d}}$ & $\frac{\pi}{2}$ \\
$\frac{\pi}{\alpha}$ & $\frac{\pi}{\alpha}$ & $\frac{\pi}{\alpha}$ \\
& &
\end{tabular} & 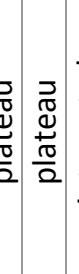 & 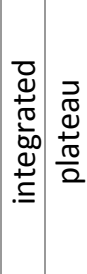 & 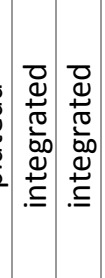 & & & & 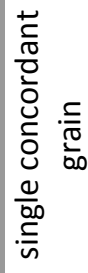 & 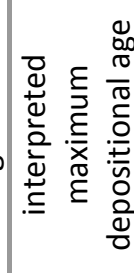 \\
\hline 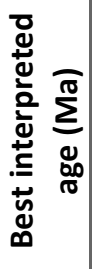 & $\begin{array}{l}m \\
0 \\
+1 \\
+ \\
\infty \\
\infty \\
\infty\end{array}$ & 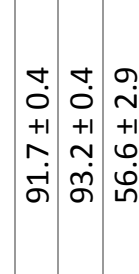 & 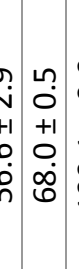 & 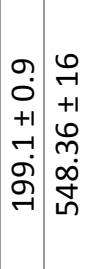 & 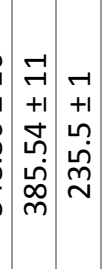 & 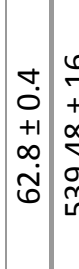 & 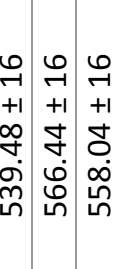 & $\begin{array}{l}0 \\
1 \\
+1 \\
\omega \\
\end{array}$ & 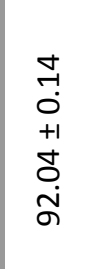 & 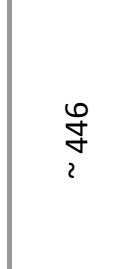 \\
\hline 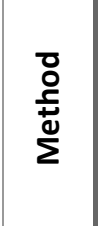 & 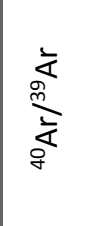 & 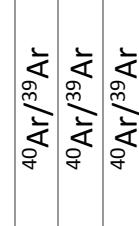 & 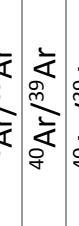 & 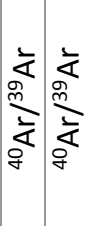 & 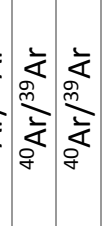 & 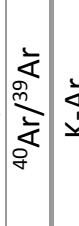 & & 京 & 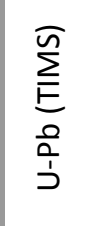 & 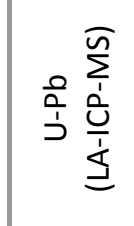 \\
\hline 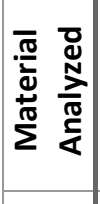 & 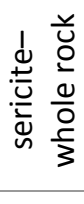 & 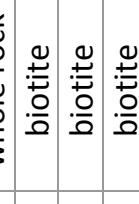 & 气. & \begin{tabular}{l|l}
$\frac{0}{0}$ & $\frac{0}{0}$ \\
$\frac{0}{0}$ & $\frac{0}{0}$ \\
$\frac{0}{0}$ & $\frac{5}{5}$ \\
$\frac{c}{3}$ & 0 \\
\end{tabular} & 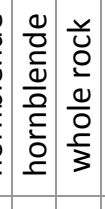 & 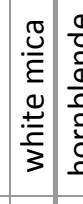 & 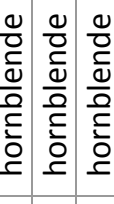 & $\begin{array}{l}\frac{0}{0} \\
\frac{0}{0} \\
\frac{0}{2}\end{array}$ & 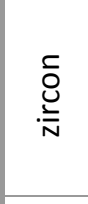 & 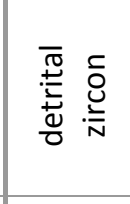 \\
\hline$\sum_{2}^{\frac{2}{\pi}}$ & 喜 & 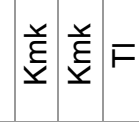 & $=\mid$ & $\begin{array}{l}\text { है } \\
\text { है } \\
\underline{\underline{N}}\end{array}$ & ? & & 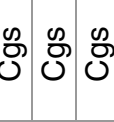 & 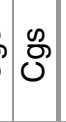 & 亗 & $\begin{array}{l}0 \\
\stackrel{\mathcal{E}}{N} \\
\underline{\underline{N}}\end{array}$ \\
\hline 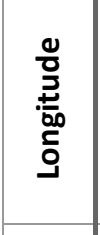 & 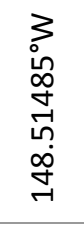 & 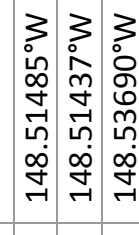 & 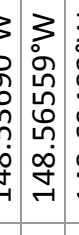 & 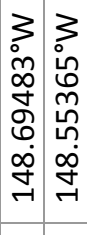 & 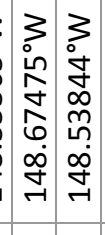 & 3 & 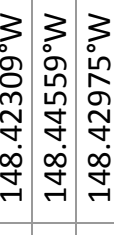 & & 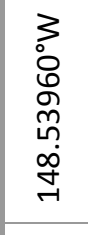 & 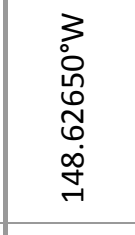 \\
\hline 旁 & $\begin{array}{l}z \\
0 \\
0 \\
0 \\
1 \\
1 \\
10\end{array}$ & 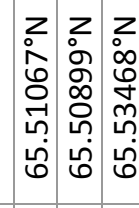 & 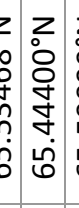 & 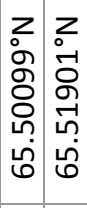 & $\begin{array}{lll}z & z \\
0 & 2 \\
\hat{N} & \hat{N} \\
0 & 0 \\
0 & 0 \\
1 & 0 \\
0 & 0 \\
0 & 0\end{array}$ & 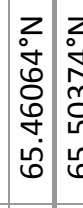 & 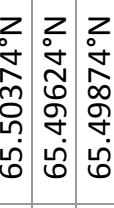 & & 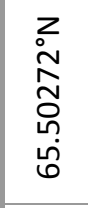 & 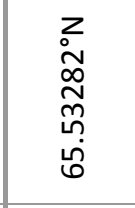 \\
\hline 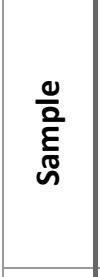 & 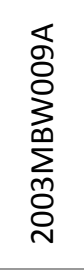 & 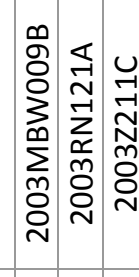 & 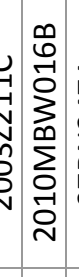 & 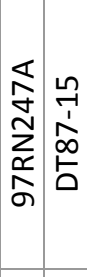 & 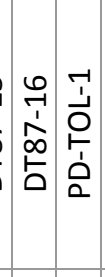 & 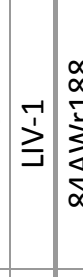 & 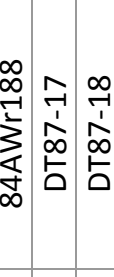 & 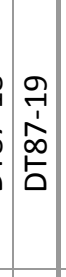 & 1 & 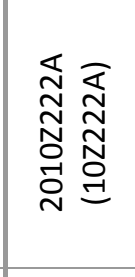 \\
\hline$\sum^{\pi} \frac{0}{2}$ & $\bar{\psi}$ & 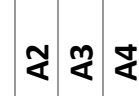 & & \& $₹$ & \& & $\frac{9}{4} 5$ & 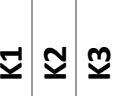 & $\mathbf{\Psi}$ & 5 & 0 \\
\hline
\end{tabular}


total combined thickness of $>75 \mathrm{~m}$ is suggested for these two units (Chapman and others, 1980). The lower, clastic unit (Ss) lies unconformably on the Ordovician Livengood Dome chert unit (Old; this study; Weber and others, 1992).

\section{LIVENGOOD DOME UNIT}

Massive, variegated chert and minor clastic sedimentary rocks of the Livengood Dome unit (Old) are dated as Late Ordovician by graptolites from the Livengood C-4 Quadrangle, $4.2 \mathrm{~km}$ west of the map area (Weber and others, 1994). The rhythmically interbedded chert and shale with subordinate siltstone, sandstone, and conglomerate are interpreted to represent a relatively deep-water depositional environment, probably outer continental shelf to upper slope depths (R.B. Blodgett, written commun., 2004). The presence of graptolites, radiolaria, and sponge spicules are consistent with this interpretation, as well as the notable lack of shelly fauna (Weber and others, 1994; R.B. Blodgett, written commun., 2004). Chapman and others (1980) suggest a thickness for this unit of 300-600 m.

\section{MAFIC AND ULTRAMAFIC ASSEMBLAGE}

The early Cambrian mafic and ultramafic assemblage, a mixture of greenstone (€gs), metagabbro (€mg), and serpentinite ( $€ s$ ) occur on Amy Dome, Money Knob, and Cascaden Ridge. These units correlate in composition and age with unit €Zum of Weber and others (1992) and are described in detail by Foster (1966). The Cambrian assemblage displays a mid-ocean ridge basalt (MORB) trace-element signature (Athey and others, 2004c) and may represent a differentiated sill complex (Cady and Morin, 1990) or an obducted slab of oceanic crust. This assemblage is metamorphosed to prehnite-pumpellyite facies (Foster, 1966; Athey and Craw, 2004).

Hornblende from a metagabbro (unit $€ \mathrm{mg}$ ) $0.75 \mathrm{~km}$ southwest of the town of Livengood yields an ${ }^{40} \mathrm{Ar} /{ }^{39} \mathrm{Ar}$ plateau age of $535.3 \pm 2.7 \mathrm{Ma}$ (Athey and others, 2004a). This sample previously yielded a K-Ar hornblende age of $548 \pm$ 16 (Rinehart and others, 1997); the older age is explained by excess argon released from the lowest step-heated fractions during the ${ }^{40} \mathrm{Ar} /{ }^{39} \mathrm{Ar}$ dating process (Athey and others, 2004a). Several other late Proterozoic K-Ar hornblende ages from this unit (map locations K1-K4; Rinehart and others, 1997) probably also contain excess argon. An early Cambrian age is assigned to the mafic and ultramafic assemblage present in the map area.

\section{WICKERSHAM UNITS}

Wickersham limestone ( $€ w l)$ outcrops in one location in the north of the map area and corresponds with additional outcrops of $€ w l$ mapped by Weber and others (1992) along strike to the east and west. The Wickersham shale unit (€Zwa) is interpolated to be present under Quaternary cover as an extension of outcrops mapped by Weber and others (1992) to the east and west of our map area. The ages of these units are unknown; however, a maximum age of late Proterozoic is assigned because of their stratigraphic position above the Wickersham grit (€Zwg) (Weber and others, 1988; Weber and others, 1992), which in the Livengood D-2 Quadrangle contains trace fossil Oldhamia of Cambrian to Precambrian age (Weber and others, 1994). There is no evidence that unit ЄZwg (Weber and others, 1988) is present in the map area; however, ЄZwg is mapped in the northeast corner of the Livengood Quadrangle (Weber and others, 1988) and in the Tanana Quadrangle (Reifenstuhl and others, 1998). Quartzite from the Wickersham unit is compatible with a cratonic provenance, based on its uniform composition of subrounded to well-rounded, monocrystalline quartz (Gergen and others, 1988). A detrital zircon sample from unit $€ Z w g$ in the Tanana Quadrangle has a distinctive age population consistent with a Laurentian provenance (Bradley and others, 2007).

\section{ROCKS NORTH OF THE VICTORIA CREEK FAULT}

Incipiently metamorphosed Jurassic(?) to Triassic gabbro and chert (unit kg), Triassic to Devonian sedimentary rocks (unit KDs), and Permian(?) to Devonian sedimentary rocks (unit PDs) subcrop in the northwest corner of the map area, northwest of the Victoria Creek fault. This structure, a major right-lateral, strike-slip fault, is considered to be a strand of the Tintina fault (Wheeler and Weber, 1988).

The Jurassic(?) to Triassic gabbro and chert unit $(\mathrm{kg})$ is correlated with unit kMrv of the Rampart Group (Weber and others, 1992) and is included in unit Jktmu of the Tozitna assemblage (table 3; Wilson and others, 1998). The Rampart Group forms a semicontinuous belt of volcanic, intrusive, and sedimentary rocks that extends for at least $225 \mathrm{~km}$ along an east-west axis through the Circle, Livengood, and Tanana quadrangles (Weber and others, 1992; Wilson and others, 1998). The Rampart Group is composed of oceanic igneous rocks and associated sedimentary rocks (Wilson and others, 1998). The age of this unit is constrained by Triassic radiolaria found in interlayered chert from the Livengood C-5 Quadrangle (Weber and others, 1994). Hornblende from gabbro that intrudes Rampart Group volcanic rocks in the eastern Tanana Quadrangle yields a minimum K-Ar age of $210 \pm 6 \mathrm{Ma}$ (Brosgé and others, 1969; age recalculated by Wilson and others [1998]). These igneous rocks in the Rampart and Livengood areas have a within-plate basalt trace-element signature that may indicate back-arc rifting in a marine environment (Griesel and others, 2010; Newberry and Haug, 1997; Athey and others, 2004c).

In the map area, the Permian(?) to Devonian sedimentary rocks (unit PDs) occur as rare low mounds and float of shale and mudstone. This unit correlates with unit PDms of Weber and others (1992), and elsewhere in the Livengood quadrangle it contains limestone debris flows and turbiditic sedimentary structures. The age of the unit is based on Devonian conodonts from the Livengood C-3 Quadrangle $15.2 \mathrm{~km}$ northeast of the map area and late Paleozoic (early Permian?) echinoderm debris from the Livengood C-3 Quadrangle 7.6 $\mathrm{km}$ north of the map area (Weber and others, 1994). 
Table 3. Stratigraphic correlations in the Livengood Quadrangle, Alaska.

\begin{tabular}{|c|c|c|c|c|}
\hline & Livengood Quadrangle & Livengood Quadrangle & Livengood Quadrangle & Other Equivalents \\
\hline Map Unit & $\begin{array}{l}\text { Livengood area } \\
\text { equivalent }\end{array}$ & $\begin{array}{l}\text { Schwatka-Rampart } \\
\text { area equivalent }\end{array}$ & $\begin{array}{c}\text { Fairbanks-White } \\
\text { Mountains area equivalent }\end{array}$ & \\
\hline (this report) & (Weber and others, 1992) & (Weber and others, 1992) & (Weber and others, 1992) & \\
\hline $\begin{array}{l}\text { Rampart gabbro, } \\
\text { quartz gabbro, and } \\
\text { minor chert }(\mathrm{kg})\end{array}$ & - & $\begin{array}{l}\text { Rampart group intrusive } \\
\text { and extrusive mafic } \\
\text { rocks, and sedimentary } \\
\text { rocks ( } \mathrm{kMrv} \text { ) }\end{array}$ & - & $\begin{array}{l}\text { Described within Tozitna } \\
\text { assemblage mafic and } \\
\text { ultramafic rocks (Jktmu; } \\
\text { Wilson and others, 1998) }\end{array}$ \\
\hline $\begin{array}{l}\text { Sandstone, shale, } \\
\text { and chert (kDs) }\end{array}$ & - & $\begin{array}{l}\text { Rampart group sedimen- } \\
\text { tary rocks ( } \mathrm{kMrs)} \mathrm{or} \\
\text { metamorphic and sedi- } \\
\text { mentary rocks (PDms) }\end{array}$ & - & - \\
\hline Shale (PDs) & - & $\begin{array}{l}\text { Metamorphic and sedi- } \\
\text { mentary rocks (PDms) }\end{array}$ & - & - \\
\hline $\begin{array}{l}\text { Cascaden Ridge } \\
\text { sandstone, shale, } \\
\text { and conglomerate } \\
\text { (Dc, Dcu, Dcl) } \\
\end{array}$ & $\begin{array}{l}\text { Cascaden Ridge sedi- } \\
\text { mentary unit (Dc) and } \\
\text { Quail sedimentary unit } \\
\text { (Dq) }\end{array}$ & - & $\begin{array}{l}\text { Beaver Bend sedimentary } \\
\text { unit (Dcg) and upper } \\
\text { Devonian section of Tolo- } \\
\text { vana limestone (DSt) }\end{array}$ & - \\
\hline $\begin{array}{l}\text { Lost Creek lime- } \\
\text { stone (SI) }\end{array}$ & $\begin{array}{l}\text { Lost Creek unit limestone } \\
\text { (SDI) }\end{array}$ & - & $\begin{array}{l}\text { lower Silurian section of } \\
\text { Tolovana limestone (DSt) }\end{array}$ & - \\
\hline $\begin{array}{l}\text { Lost Creek sand- } \\
\text { stone, siltstone, } \\
\text { shale, and } \\
\text { conglomerate (Ss) }\end{array}$ & $\begin{array}{l}\text { Lost Creek unit sedimen- } \\
\text { tary rocks (SDI) }\end{array}$ & - & $\begin{array}{l}\text { lower Silurian section of } \\
\text { Tolovana limestone (DSt) }\end{array}$ & - \\
\hline $\begin{array}{l}\text { Livengood Dome } \\
\text { chert (Old) }\end{array}$ & $\begin{array}{l}\text { Livengood Dome chert } \\
\text { (Old) }\end{array}$ & - & $\begin{array}{l}\text { upper(?) sedimentary por- } \\
\text { tion of Fossil Creek unit } \\
\text { (Ofs) }\end{array}$ & - \\
\hline $\begin{array}{l}\text { Amy Creek dolo- } \\
\text { mite (IPZZd), meta- } \\
\text { basalt (IPZZmb), and } \\
\text { mudstone and } \\
\text { chert (IPZZmc) } \\
\text { assemblage }\end{array}$ & $\begin{array}{l}\text { Amy Creek dolomite, } \\
\text { chert, argillite, } \\
\text { mudstone, and } \\
\text { greenstone (SZa) }\end{array}$ & - & $\begin{array}{l}\text { (?) lower(?) sedimentary } \\
\text { portion of Fossil Creek unit } \\
\text { (Ofs) and Fossil Creek } \\
\text { volcanics (Ofv) }\end{array}$ & $\begin{array}{l}\text { (?) Precambrian Katakturuk } \\
\text { dolomite of Clough and } \\
\text { Goldhammer (2000) }\end{array}$ \\
\hline $\begin{array}{l}\text { Mafic and ultrama- } \\
\text { fic assemblage- } \\
\text { greenstone (€gs), } \\
\text { metagabbro (€mg), } \\
\text { serpentinite (€s), } \\
\text { and sediments } \\
\text { (€mks) }\end{array}$ & $\begin{array}{l}\text { Ultramafic and mafic } \\
\text { rocks (€Zum) }\end{array}$ & - & - & - \\
\hline $\begin{array}{l}\text { Wickersham lime- } \\
\text { stone (€wl) }\end{array}$ & $\begin{array}{l}\text { Wickersham dark-gray } \\
\text { limestone (€wl) }\end{array}$ & - & - & - \\
\hline $\begin{array}{l}\text { Wickersham shale } \\
\text { (€Zwa) }\end{array}$ & $\begin{array}{l}\text { Wickersham maroon and } \\
\text { green argillite, phyllite, } \\
\text { quartzite, graywacke, } \\
\text { siltite, and grit (€Zwa) }\end{array}$ & - & - & - \\
\hline
\end{tabular}


We interpret the contact between the Permian(?) to Devonian sedimentary rocks and the Rampart Group in the map area to be a high-angle fault that is subparallel to the Victoria Creek fault; however, the relationship between sedimentary unit $\mathrm{kDs}$ and adjacent units $\mathrm{kg}$ and PDs is unclear (table 3). The mixed sedimentary unit (KDs) may be equivalent to either the Triassic sedimentary rocks of the Rampart Group to the north (unit kMrs; Weber and others, 1992) or the Permian to Devonian sedimentary rocks to the south (PDms; Weber and others, 1992). Because of the stratigraphic uncertainty associated with sedimentary unit $\mathrm{kDs}$, the high-angle fault may be located at either the $\mathrm{kDs}-\mathrm{kg}$ contact or the kDs-PDs contact. Until this ambiguity can be resolved, this unit is assigned a Triassic to Devonian age.

\section{STRUCTURAL GEOLOGY}

The structural geology of the map area is best described in terms of four belts of rocks with different structural styles (see fig. 3). From northwest to southeast they include: (1) the Livengood Dome and Lost Creek units (Old, Ss, and SI);
(2) the Amy Creek units (IPZZd, IPZZmb, and $\mathbb{P} Z \mathbf{Z} Z \mathbf{Z} c)$; (3) the Cascaden Ridge (Dc, Dcl, and Dcu) and Cambrian mafic and ultramafic units (€s, €mg, €gs, and €mks); and (4) the Wilber Creek sedimentary units (Kwcf, Kwcs, and Kwcc). The Wickersham units (€Zwa and $€ w l$ ) and the rocks north of the Victoria Creek fault have extremely limited exposure in this map area and will not be discussed.

The systematic dispersion of bedding measurements in the Livengood Dome (Old) and overlying Lost Creek units (Ss and SI) indicates tight folding with northeasterly-trending axes (fig. 3); the lack of exposure makes it unclear whether these folds may be asymmetric or overturned. This fold axis orientation is subparallel to the structures that bound the unit. The Amy Creek units (IPZZd, IPZZmb, and IPZZmc) comprise the second structural belt south of the Victoria Creek fault. These units are broadly folded, with axial traces subparallel to the trend of either the northern or southern margins of the belt (fig. 3). Folds in the Amy Creek units become tighter and limbs are occasionally overturned in proximity to the thrust contact with the mafic and ultramafic units to the south.

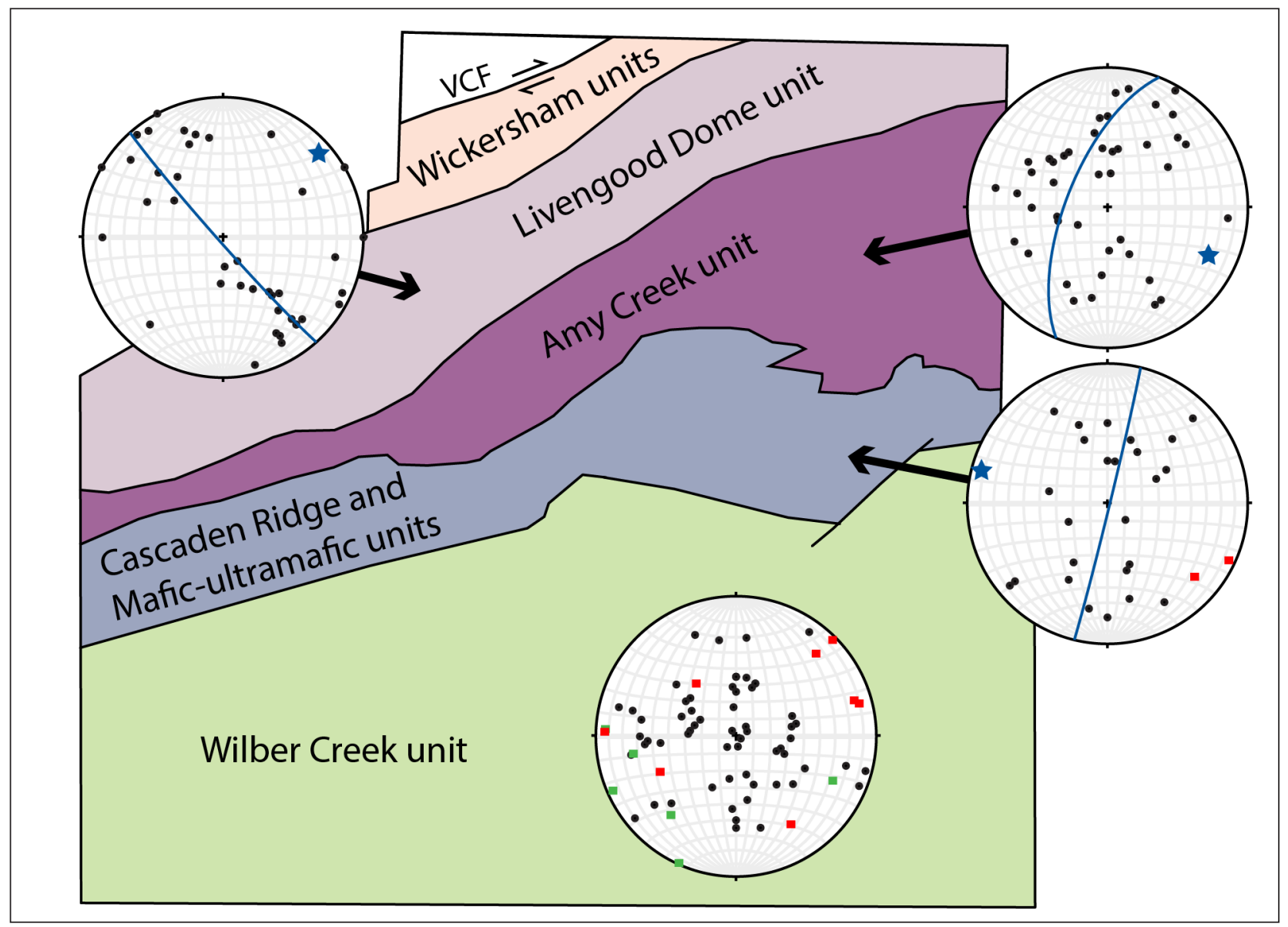

Figure 3. Equal-area stereographic plots illustrating selected structural measurements for map-scale structural domains. Black dots represent poles to bedding measurements. Red squares represent measured fold axes. Blue stars and corresponding blue girdles indicate the best-fit average cylindrical fold axis for each domain. Green squares represent bedding cleavage intersection lines from the Wilber Creek unit. No measurements were collected from the Wickersham units. Plots created using the program Stereonet (Allmendinger and others, 2012). 
The Cascaden Ridge units (Dc, Dcl, Dcu, Dcv, and Di) and the Cambrian mafic and ultramafic assemblage (units $€ g s, € m g, € m k s, € s$ ) comprise the third structural panel, which is structurally juxtaposed over the Amy Creek units on a south-dipping thrust fault. The Cambrian mafic-ultramafic unit consists of thin, thrust-imbricated layers of greenstone (€gs), metagabbro (€mg), and sedimentary rocks (€mks) commonly separated by thin sheets of serpentinite (€s). This imbricated mafic-ultramafic panel is in turn thrust-stacked with the Cascaden Ridge unit. Both inferred and measured fold axes from this unit (fig. 3) generally parallel the eastwest trend of the thrust faulting and the contact with the Amy Creek units to the north.

The fourth structural domain encompasses the Wilber Creek units (Kwcf, Kwcs, and Kwcc) in the southern half of the map area. We observed centimeter- to kilometer-scale upright and recumbent folds of bedding with a variety of orientations throughout the Wilber Creek unit (fig. 3). A moderately spaced cleavage is parallel, oblique, and perpendicular to bedding and interpreted as axial planar to map-scale folding. Measured bedding-cleavage intersections plunge southwest or southeast, and inferred and measured fold axis orientations are grossly divided into northeast-southwest- and northwestsoutheast-trending populations. The highly scattered aspect of these measurements (fig. 3) may reflect deformation and rotation related to the many high-angle faults identified in the southeast quadrant of the map.

\section{THRUST FAULTING}

The contact between the Cascaden Ridge unit and the Wilber Creek unit is largely concealed throughout the map area; however, in the area of Sawtooth Mountain west of the map area, Wilber Creek unit rocks are mapped as interleaved with Paleozoic rocks on south- and east-dipping thrust faults. Southwest of the map area, the south-dipping Beaver Creek thrust fault emplaces Paleozoic rocks of the White Mountains area over the Wilber Creek unit (Weber and others, 1992). This regional thrust faulting is consistent with the northwest-southeast-directed compression (inferred from northeast-southwest-trending fold axes) observed for much of the Wilber Creek unit in the map area.

At the western edge of the map area, the early Late Cretaceous Cascaden Ridge pluton (unit Kcrp) intrudes both the Cascaden Ridge unit and the thrust-juxtaposed Cambrian mafic-ultramafic units. Similarly, drilling by ITH at Money Knob shows that the $\sim 90$ Ma Money Knob dikes (unit Kmk) cut the thrust contacts in that location as well. Regionally, a belt of $\sim 90 \mathrm{Ma}$ alkaline plutons, including the Sawtooth and Roughtop Mountain plutons, intrudes both Wilber Creek and Cascaden Ridge equivalents (Weber and others, 1992; Reifenstuhl and others, 1998), indicating that thrust faulting had taken place by that time. From the above evidence it follows that thrust-fault imbrication of the Cascaden Ridge, Cambrian mafic-ultramafic, and Wilber Creek units likely took place during the early Late Cretaceous.

While they are deformed by east-west to northeast-southwest-trending folds that are permissive of compressional deformation, the Amy Creek units and rocks to the north are not clearly linked with the Cascaden Ridge and Cambrian mafic-ultramafic by piercing intrusions. The lack of middle to Late Cretaceous intrusions in the Amy Creek unit could indicate that the rocks to the south were structurally emplaced to their present position after cessation of Cretaceous magmatism. However, the Cascaden Ridge sandstones (for example, unit Dc) apparently contain detritus of the Livengood Dome or Amy Creek units (Gergen and others, 1988), indicating that these structural panels were not greatly separated during Devonian time. An alternative explanation for the deformation of the Amy Creek units is offered by Late Triassic to Early Jurassic ${ }^{40} \mathrm{Ar} /{ }^{39} \mathrm{Ar}$ whole rock ages (230 and $199 \mathrm{Ma}$ ) for Amy Creek metabasalt (IPZZmb) (Athey and others, 2004a), which could indicate that major tectonism and thermal reset occurred at an earlier time.

\section{HIGH-ANGLE FAULTING}

Several sets of high-angle faults cut the map area. These faults appear to cut the four structural domains described above; however, they appear to be mostly concentrated in the southern and eastern areas of the map that have better exposure. The youngest of these is the Myrtle Creek fault, which cuts Pliocene(?) gravels of the Livengood bench (unit QTfb). This fault and several parallel structures are traceable by sharp, apparent left-lateral offsets and discontinuities in airborne magnetic and electromagnetic maps (Burns and others, 2015). These geophysical offsets diminish toward the north and disappear south of the Wickersham units. In the vicinity of Livengood, offsets of the highly magnetic serpentinite unit $(€ s)$ is consistent with left-lateral or west-side-up displacement, whereas exposures and drilling of this fault at the Livengood bench and Lillian Creek placer mines indicate an apparent west-side-down offset during Quaternary time.

Units in the southern half of the map area are cut by a series of high-angle, northeast-trending faults with apparent dip-slip offset. Some of these faults are visible as lineaments in lidar data (Hubbard and others, 2011), while others are traceable as linear discontinuities in airborne electromagnetic data. Geophysical lineaments associated with these faults suggest that they either terminate at the Myrtle Creek fault or are cut by it. Finally, faults with generally east-west and northwest-southeast trends are poorly resolved but appear to predate the northeasterly and north-south sets.

\section{ECONOMIC GEOLOGY}

\section{PLACER GOLD}

The Livengood subdistrict, $120 \mathrm{~km}$ northwest of Fairbanks, is the most productive part of the Tolovana mining district. Approximately 542,000 ounces of placer gold have been mined from the region since 1914 (Athey and others, 2014). The Livengood bench, to the north and slightly topographically above the present Livengood Creek, is the richest gold placer in the district (Bundtzen and others, 1982) and the oldest dated placer, based on a pollen assemblage consistent with Pliocene or possibly latest Miocene (Karl and others, 1988). The Amy Creek placer may also be Neogene in age, as it is buried or truncated by an approximately $900-\mathrm{m}$-wide 
landslide deposit (unit Qcl) in upper Amy Creek. Reger and Burns (2013) indicate that the landslide deposits in the map area are relatively old (Pleistocene?) based on subdued headwall scarps and deep dissection of debris.

The Gertrude Creek placer was probably deposited during the Pleistocene or earlier, as the host gravels are overlain by a thick bed of loess. Woolly mammoth, saiga antelope (Péwé, 1975), and other Pleistocene fauna were found in Lillian Creek, indicating that this deposit is probably of late Pleistocene or earlier age. The ages of placer gravels in Lucky, Ruth, and Olive creeks are unknown. The proximity of lode gold mineralization at Money Knob allows for the possibility of recent placer deposition in Ruth, Lillian, and Olive creeks. Placer gold in current Livengood Creek is reworked from older gold-bearing gravels present in the Livengood watershed.

Mertie (1917) proposed that a portion of Livengood Creek once drained northeast into Hess Creek, part of the Yukon River drainage, and was subsequently captured by the Tanana River drainage, reversing its flow. Spatial variations in placer gold grain compositions and morphologies in the Livengood Creek drainage and Livengood bench support this drainage reversal hypothesis and suggest the reversal took place within the past 10 million years.

In the Money Knob area, gold grains sampled from a quartz vein (average fineness 891 ) and an intrusive body (average fineness 902) have fineness values remarkably similar to the average Livengood bench placer gold grain core fineness of 895 (Newberry and Athey, unpublished data). The historic headwaters of Livengood Creek probably drained from the Money Knob area, an obvious potential lode source of gold for the formation of Livengood bench.

Rounding and fineness of nuggets increase down firstorder streams draining the Money Knob-Amy Dome ridge (average rim + core fineness of 854-915; Smith, 1941; Glover, 1950; Cathrall and others, 1987; Minehane and Rogers, 1997). In Livengood Creek, nugget rounding and fineness increase toward the creek's present headwaters (average rim + core fineness of 902-925; Smith, 1941; Glover, 1950; Cathrall and others, 1987; Minehane and Rogers, 1997), the direction away from the Money Knob area. This trend is more pronounced in the morphology and composition of gold grain rims (electron microprobe analyses from Newberry and Athey, unpublished data). Silver-depleted rims on gold grains collected toward the present headwaters of Livengood Creek are progressively thicker (up to 100 microns), and more silver depleted (up to 996 fineness).

Although Livengood gold nugget composition and morphology data suggest the stream capture hypothesis is valid, the current southwesterly slope of Livengood bench is inconsistent with a reversal of drainage direction. Because the existing surface of Livengood bench parallels the surface of present Livengood Creek, one would expect the older stream to have had a southwesterly flow as well. To restore Livengood bench to its presumed past northeasterly flow along the paleo-surface, the bench must be raised up about $260 \mathrm{~m}$ on its southwestern end. A paleo-surface re- stored to horizontal requires about $120 \mathrm{~m}$ of uplift, and a paleo-surface with a gradient similar to that of the current Livengood Creek requires an additional $140 \mathrm{~m}$ of uplift. This suggests an equivalent, and not unreasonable, amount of subsidence has occurred since about $10 \mathrm{Ma}$ to create the current Livengood Creek drainage conditions. A subsidence rate of only $0.026 \mathrm{~mm} /$ year for the past 10 million years is required to change the stream gradient from northeast-flowing to southwest-flowing.

Myrtle Creek fault cuts placer deposits of the Livengood bench (unit QTfb) and thereby provides concrete evidence of tectonism since Pliocene time. Placer drill results from west side of Myrtle Creek fault indicate a sharp increase in the depth to bedrock and the appearance of a 45-60-m-thick gold-barren gravel layer that is not present east of the fault (B.I. Thomas, written commun., 1972; Karl Hanneman, oral commun., 2003). Additionally, placer miner Ronald Tucker (oral commun., 2003) observed that the surface of the bedrock steps down to the west $17 \mathrm{~m}$ in two places (for a total of $34 \mathrm{~m}$ ) on lower Lillian Creek along the trace of Myrtle Creek fault.

In addition to tectonism, southwesterly headward erosion may have been a contributing mechanism of ancient Livengood Creek's capture by the Tanana River drainage system. Headward erosion of the formerly northeast-flowing Livengood Creek may have allowed the creek to break through a former drainage divide and flow southwestward to the topographically lower Minto flats, the northern branch of the Nenana basin. Changes in base level as a result of tectonic subsidence of the Nenana basin (Barnes, 1961; Péwé and others, 1966; Reger, 1987) may also have influenced erosion rates in the Livengood area.

Placer bench deposits (shown as unit Qh) along the lower one-half mile of Wilber Creek host the only known placer gold occurrence in the southern portion of the map area. Mining took place intermittently between 1926 and 1987 by underground drift and hydraulic methods (Freeman and Schaefer, 1999), with total production of several thousand ounces of gold (Skudrzyk and others, 1987). The bedrock source of gold is unknown; however, altered porphyry intrusions (unit Ksc) subcrop in the immediate area of placer workings. Gold grain compositions from Wilber Creek have an average fineness of $\sim 850$, slightly lower but within the range of gold grain core compositions north of the Tolovana River (Szumigala and others, 2010).

\section{MONEY KNOB GOLD MINERALIZATION}

The map area contains one major lode gold deposit, the Money Knob intrusive-related gold system currently being explored by International Tower Hill Mines, Limited (ITH). As of September 2013 ITH reported a measured and indicated resource of 802 million metric tons grading 0.61 grams per metric ton gold (a total of 15.7 million ounces of gold) at a 0.30 grams per metric ton cutoff grade, plus additional inferred resources of 266 million metric tons grading 0.52 grams per metric ton (4.4 million ounces) (Samuel Engineering, 2013). 
Lode gold mineralization at Money Knob is hosted in the Devonian volcanic and sedimentary rocks of the Cascaden Ridge unit (Dc) and within the structurally emplaced Cambrian units above. Mineralization is centered on swarms of felsic dikes, many of which are well mineralized and strongly altered and in themselves constitute an important host lithology. The presently defined mineralized footprint is approximately 2.5 by $1 \mathrm{~km}$, elongate in the northeast-southwest direction, and comprises four contiguous zones. The largest of these, the Core Zone, displays a pronounced north-northeasterly trend. At depth, the overall mineralized envelope dips shallowly to the south, generally following stratigraphy (especially the favorable host Devonian volcanic unit, Dcv) except north of Lillian Creek (the Lillian fault) where the mineralization cuts stratigraphy at a high angle. Higher gold grades often show continuity in the moderate south-dipping orientation of the general structural architecture and mineralized dikes (Brechtel and others, 2011).

Gold mineralization occurs with disseminated sulfides in zones of pervasive alteration in favorable host rocks, as well as in multi-stage quartz, quartz-carbonate, and quartzcarbonate-sulfide veins and veinlets. In both styles, gold is strongly associated with the sulfides arsenopyrite, pyrite, and locally stibnite (Brechtel and others, 2011).

Three principal phases of alteration are recognized. The earliest stage affects all rock types and is characterized by remnant patches of fine-grained secondary biotite, accompanied by quartz, pyrrhotite, and possibly arsenopyrite. Vein, selvage, and pervasive sericitic alteration crosscuts secondary biotite alteration. This stage of alteration is accompanied by pyrite, arsenopyrite, and fine-grained quartz. Selvage and pervasive albite alteration are accompanied by dark, fine-grained quartz and disseminated arsenopyrite and pyrite mineralization (Brechtel and others, 2011), and albite-bearing vein selvages are observed to crosscut sericitic alteration (Nichols, 2013). A late clay alteration consisting of kaolinite, smectite, illite, quartz, ankerite, and locally chlorite (Nichols, 2013) occurs locally along fault zones and within unit Kmk; it is anomalous in gold but not characteristic of the main mineralized zones. Additionally, a significant amount of carbonate has been introduced to the Money Knob area via several styles of veinlet and disseminated alteration, including widespread carbonatization of the overlying Cambrian serpentinite (unit $€ s$ ) (Brechtel and others, 2011).

Athey and others (2004a) determined an ${ }^{40} \mathrm{Ar} /{ }^{39} \mathrm{Ar}$ plateau age of $88.9 \pm 0.3 \mathrm{Ma}$ for sericite in a strongly altered, arsenopyrite-mineralized intrusive rock from Money Knob (map location A1). Primary biotite from quartz monzonite and quartz syenite dikes (unit Kmk) in the Money Knob area yield ${ }^{40} \mathrm{Ar} /{ }^{39} \mathrm{Ar}$ plateau ages of $91.7 \pm 0.4 \mathrm{Ma}$ (map location A2) and 93.2 $\pm 0.4 \mathrm{Ma}$ (map location A3), respectively. These ages indicate that the Money Knob deposit is coeval with the intrusion-related gold deposits of the Tombstone plutonic suite, including Fort Knox near Fairbanks and Brewery Creek in the Yukon (Thompson and Newberry, 2000).

\section{POLYMETALLIC MINERALIZATION SOUTH OF THE TOLOVANA RIVER}

South of the Tolovana River, sedimentary rocks (units Kwcf, Kwcs, and Kwcc) and latest Cretaceous subalkaline intrusions (unit Ksc) host sulfide-rich polymetallic epithermal-style mineralization that is about $25 \mathrm{~m}$.y. younger and geologically and geochemically distinct from the gold mineralization at Money Knob. As at Money Knob, $\mathrm{Au}-\mathrm{Ag}$ mineralization is associated with pyrite and arsenopyrite; however, the Hill 1835 prospect shows far greater enrichment in $\mathrm{Ag}, \mathrm{Bi}$, Te, and Sn, (fig. 4), making it geochemically more similar to 'Sn-Ag' systems than to typical Interior Alaska intrusion-related gold systems.

The greater Shorty Creek prospect includes mineralization at Hill 1710 on the divide between Shorty Creek and Ranney Hollow, and at nearby Hill 1835. The Hill 1710 area was initially evaluated in the early 1970s as an antimony prospect and subsequently as a $\mathrm{Cu}-\mathrm{Mo}$ target. Field evidence (Robinson and Metz, 1979) indicates that Earth Resources drilled ten rotary holes on the south flank of Hill 1710 prior to 1974 , concluding that $\mathrm{Cu}-\mathrm{Mo}-\mathrm{Ag}$ mineralization is associated with felsic dikes and sills intruding the Wilber Creek sediments (Freeman, 2010). Renewed exploration in the late 1980s focused on anomalous $\mathrm{Au}, \mathrm{Cu}$, and associated pathfinder elements in the Hill 1835 area. The project ultimately became a joint venture of Fairbanks Exploration Inc. and Asarco Inc. and culminated in the drilling of 20 reverse-circulation holes totaling $6,844 \mathrm{ft}(2,086 \mathrm{~m})$ at Hill 1835 (Freeman, 2010). Freegold Ventures Ltd. conducted soil sampling and induced-polarization (IP) surveys on the property in 2014, leading to a four-hole drill program in 2015 that intercepted $91 \mathrm{~m}$ grading 0.55 percent $\mathrm{Cu}, 0.14$ grams per metric ton $\mathrm{Au}$, and 7.02 grams per metric ton $\mathrm{Ag}$ at Hill 1835 (Freegold Ventures Ltd., November 16, 2015 press release).

\section{Mineralization}

Mineralization at Hill 1835 is hosted almost exclusively by altered sedimentary rocks, both as disseminated type and in silicified breccias and sulfide-rich veinlets. In drilling, the mineralization has a northeasterly-elongate footprint and a shallowly dipping, possibly stratigraphically controlled geometry in cross section.

Previously reported hypogene mineralogy includes pyrite (seen at surface as a distinctive coarse-grained cubic boxwork), arsenopyrite, pyrrhotite, chalcopyrite, bornite, stibnite, and galena (Freeman, 2010). Investigation of sulfide-rich drill cuttings collected around the site of reverse-circulation drillhole 7 indicates the presence of pyrite, arsenopyrite, chalcopyrite, bismuthinite, and rare pyrrhotite. Pyrrhotite and chalcopyrite occur as inclusions in pyrite and arsenopyrite; bismuthinite is exclusively present in or immediately adjacent to arsenopyrite. Microprobe examination confirmed all these minerals and also showed that the bismuthinite commonly contains about 1 percent $\mathrm{Sb}$. No additional minerals were found with the microprobe except rare stannite $\left(\mathrm{Cu}_{2} \mathrm{FeSnS}_{4}\right)$ as inclusions in arsenopyrite. Tourmaline was commonly present as $0.1 \mathrm{~mm}$ euhedral grains intergrown with pyrite. 


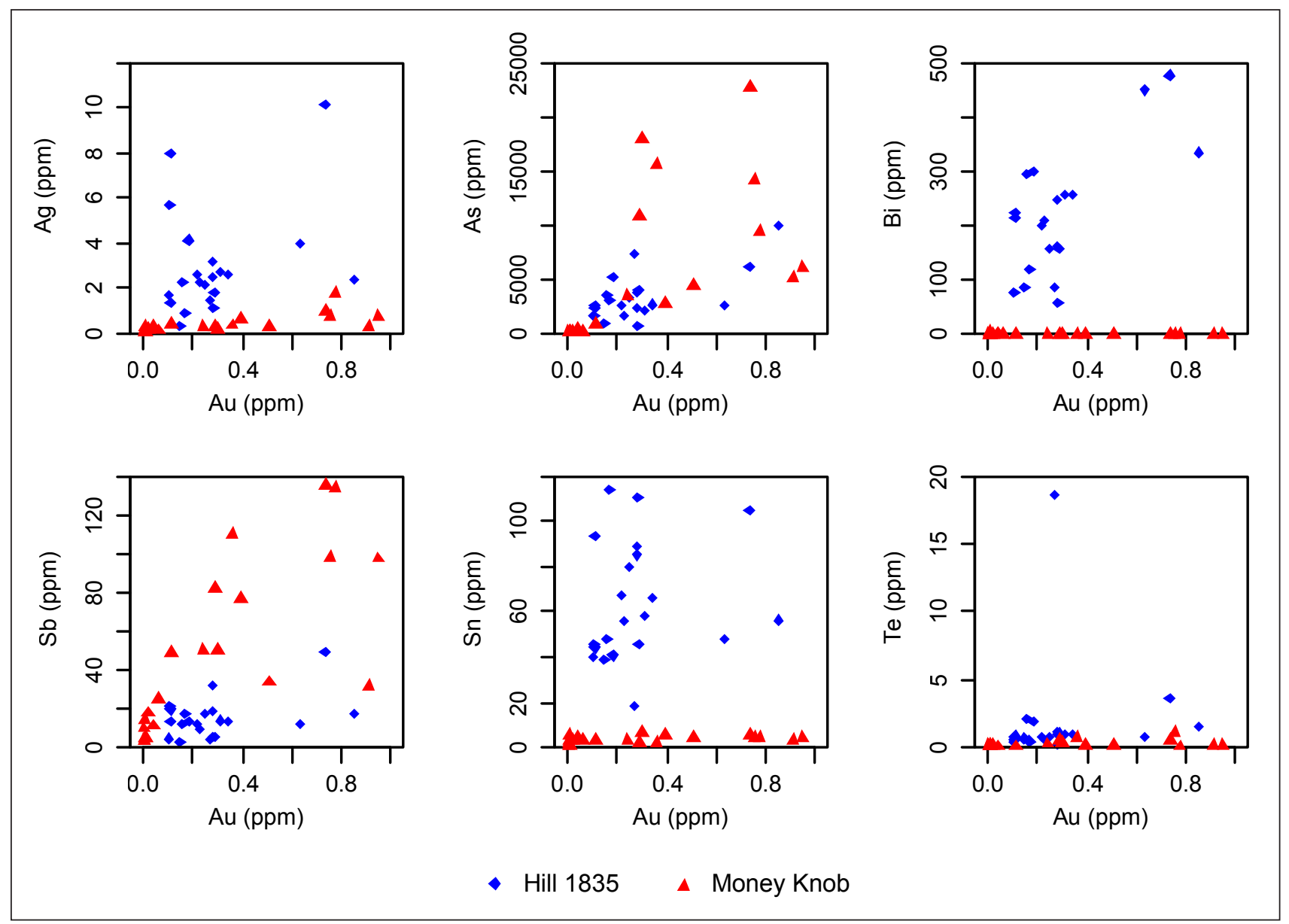

Figure 4. Suite of bivariate geochemical plots, showing the differences in trace elements associated with gold mineralization at Hill 1835 and at Money Knob. Money Knob data (red symbols) are from Nichols (2013), and Hill 1835 data (blue symbols) are from Griesel and others (2010).

Deep oxidation has affected the prospect, and partial oxidation extends beyond the $500 \mathrm{ft}(152 \mathrm{~m})$ limit of pre2015 drilling (Freeman, 2010). $\mathrm{Au}-\mathrm{Ag}$ and $\mathrm{Cu}$ mineralized zones are spatially separate, with $\mathrm{Au}-\mathrm{Ag}$ closer to the surface and $\mathrm{Cu}$ mineralization restricted to depths of greater than $350 \mathrm{ft}(106.7 \mathrm{~m})$. The lack of strong $\mathrm{Ag}-\mathrm{Cu}$ correlation and the presence of locally elevated $\mathrm{Au}$ and $\mathrm{Ag}$ values correlating with $\mathrm{Cu}$ mineralization suggest that this zonation may reflect hypogene processes rather than supergene leaching and enrichment.

DGGS sampling (Griesel and others, 2010) yielded several anomalous Mo values up to $281 \mathrm{ppm}$ from rocks in the Hill 1710 area. All of the highly anomalous samples come from either altered Shorty Creek type intrusions (unit Ksc) or from quartz-veined and altered sedimentary rocks in the immediate vicinity of these intrusions. The distribution of DGGS samples indicates that anomalous Mo occurrences are restricted to a northeast-trending belt in the Hill 1710 area, separated from $\mathrm{Au}-\mathrm{As}$ mineralization at Hill 1835 by at least one northeasterly-striking fault. The differences in the apparent geochemical signatures of Hill 1710 and Hill 1835 might reflect differing levels of exposure.

\section{Alteration}

Investigations conducted for this report indicate that what has been previously described as biotite-diopside hornfels is in fact a fine-grained alteration assemblage dominated by quartz and tourmaline. The textural and mineralogical changes are associated with progressive changes in bulk composition, a pattern that is characteristic of hydrothermal alteration and inconsistent with simple contact metamorphism.

Alteration at the Hill 1835 prospect varies according to protolith. Siltstone interbeds in the Wilber Creek flysch (Kwcf) are fine grained, very-dark-gray to black, and evidently carbonaceous. Least-altered mineralogy (determined by X-ray diffraction [XRD]) includes quartz, chlorite, muscovite, and albite. This lithology is progressively altered to a durable, very-fine-grained quartz-tourmaline assemblage. The tourmaline is essentially invisible in hand specimen and thin section due to its fine grain size and Mg-rich composition. In thin section, the rock is composed of fine-grained $(0.1 \mathrm{~mm})$ quartz-tourmaline intergrowths. Apart from a major increase in $\mathrm{SiO}_{2}$, the rock is strongly depleted of $\mathrm{K}_{2} \mathrm{O}$, $\mathrm{Fe}_{2} \mathrm{O}_{3}, \mathrm{MnO}, \mathrm{CaO}$, and $\mathrm{P}_{2} \mathrm{O}_{5}$ (fig. 5). Laser-ablation ICP-MS 
analyses of six rocks identified by XRD as having a tourmaline-quartz assemblage average 3.7 percent $\mathrm{B}_{2} \mathrm{O}_{3}$, indicating the rocks are roughly 30-40 percent tourmaline.

In contrast to the siltstone component of the flysch, the wacke component is considerably more sensitive to hydrothermal alteration and the changes are more readily recognized (fig. 6). Unaltered wacke is dominated by albite, quartz, muscovite, chlorite, and calcite. In moderately altered rocks, calcite is lost and albite is replaced by fine-grained quartz and sericite. Strongly altered wacke is nearly pure white (where not stained by iron oxide), porous, and distinctly granular. It contains 3 to 20 percent cubic boxworks (1-8 $\mathrm{mm}$ ) after weathered-out pyrite. Strongly altered wacke is characterized by a fine-grained assemblage of quartz, muscovite, and nearly colorless, Mg-rich tourmaline.
Chemically, the altered rocks are strongly depleted in $\mathrm{Na}_{2} \mathrm{O}, \mathrm{MnO}$, and $\mathrm{CaO}$, and moderately enriched in $\mathrm{SiO}_{2}$ and $\mathrm{K}_{2} \mathrm{O}$. The abundance of tourmaline indicates strong boron enrichment. The alteration corresponds to progressive enrichment of As, Bi, Ag, Sn, and W. The zone of intense quartz-muscovite-tourmaline alteration broadly coincides with the area of drill-defined gold mineralization at Hill 1835.

The majority of the known mineralization occurs on Hill 1835 and is hosted by sediments; however, sericitized and weakly mineralized porphyry intrusions of unit Ksc contain anomalous Mo in at least one location. McCoy (2000) reports an ${ }^{40} \mathrm{Ar}{ }^{39} \mathrm{Ar}$ plateau age of $62.8 \pm 0.4 \mathrm{Ma}$ for white mica alteration of an intrusion at the Ranney Hollow prospect near Hill 1710. This age is assumed to apply to quartz-muscovitetourmaline alteration at Hill 1835.
Figure 5. Progressive transformation (left to right) of siltstone interbeds of unit Kwcf into the 'hornfels' seen at the Hill 1835 prospect. The data are average direct XRF analyses for 5-10 samples of each type: unaltered, weakly altered, and strongly altered.

* Data for $\mathrm{B}_{2} \mathrm{O}_{3}$ were measured by Laser Ablation ICP-MS at UAF.

$-=$ Not analyzed .

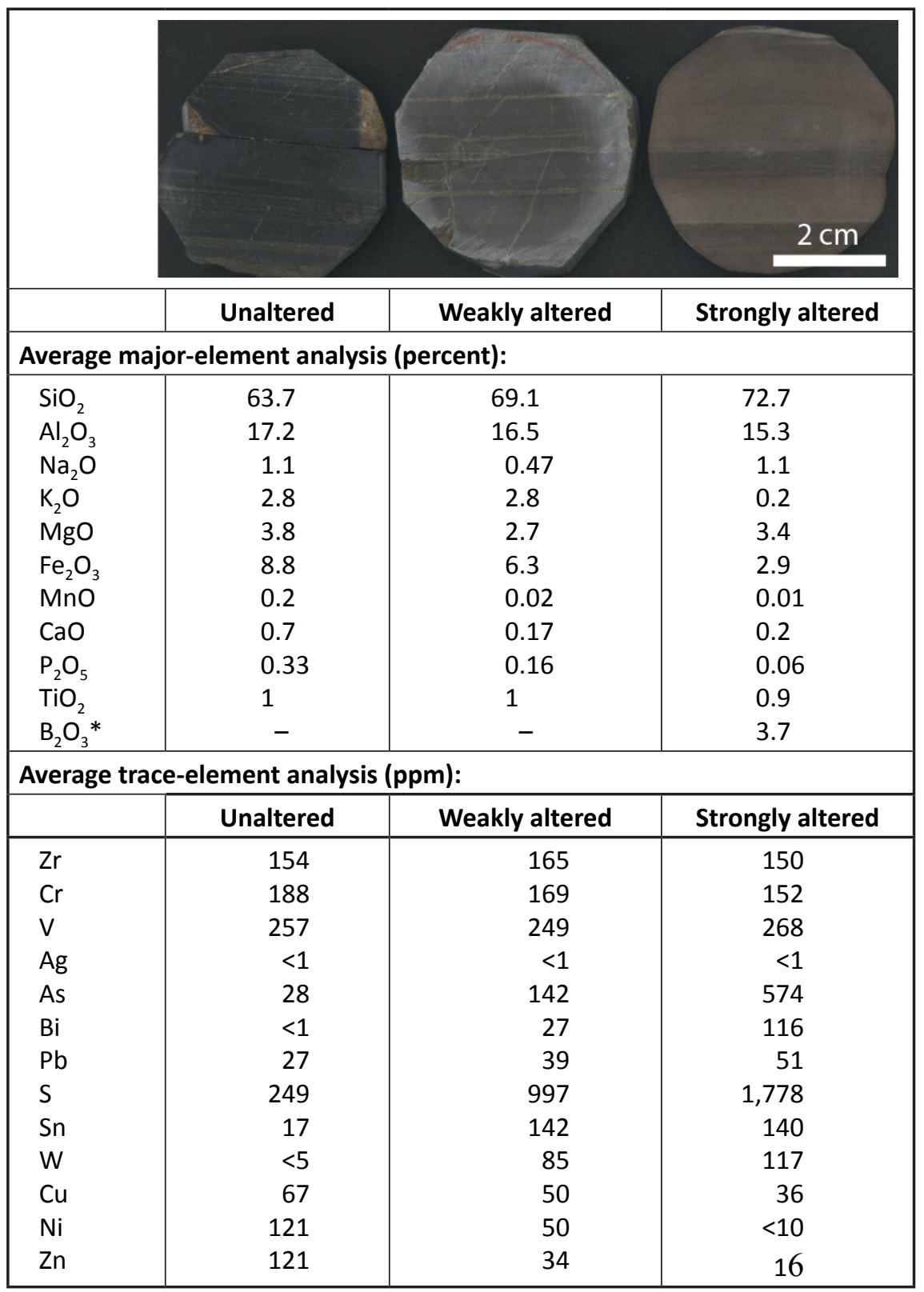




\begin{tabular}{|c|c|c|c|c|c|}
\hline \multicolumn{6}{|c|}{ Alteration intensity: } \\
\hline & Unaltered & Very weak & Weak & Moderate & Strong \\
\hline \multicolumn{6}{|c|}{ Average major element analysis (percent): } \\
\hline $\mathrm{SiO}_{2}$ & 69.5 & 75.4 & 77.3 & 75.2 & 81.4 \\
\hline $\mathrm{Al}_{2} \mathrm{O}_{3}$ & 12.3 & 11.9 & 11.6 & 13.6 & 10.2 \\
\hline $\mathrm{Na}_{2} \mathrm{O}$ & 3.6 & 1.8 & 0.05 & 0.12 & 0.4 \\
\hline $\mathrm{K}_{2} \mathrm{O}$ & 1.2 & 2.1 & 2.3 & 5.1 & 1.8 \\
\hline $\mathrm{MgO}$ & 2.4 & 2 & 1.7 & 1.5 & 1.4 \\
\hline $\mathrm{Fe}_{2} \mathrm{O}_{3}$ & 6 & 5.3 & 6.1 & 3.2 & 3.3 \\
\hline $\mathrm{MnO}$ & 0.14 & 0.06 & 0.05 & 0.012 & 0.007 \\
\hline $\mathrm{CaO}$ & 2.4 & 0.26 & 0.08 & 0.11 & 0.09 \\
\hline $\mathrm{P}_{2} \mathrm{O}_{5}$ & 0.28 & 0.25 & 0.19 & 0.1 & 0.1 \\
\hline $\mathrm{TiO}_{2}$ & 0.72 & 0.6 & 0.64 & 0.85 & 0.78 \\
\hline \multicolumn{6}{|c|}{ Average trace element analysis (ppm): } \\
\hline & Unaltered & Very weak & Weak & Moderate & Strong \\
\hline $\mathrm{Zr}$ & 99 & 127 & 120 & 144 & 138 \\
\hline $\mathrm{Cr}$ & 114 & 131 & 132 & 158 & 140 \\
\hline $\mathrm{V}$ & 152 & 147 & 140 & 181 & 152 \\
\hline $\mathrm{Ag}$ & $<1$ & $<1$ & $<1$ & 1 & 4 \\
\hline As & 4 & 46 & 83 & 90 & 910 \\
\hline $\mathrm{Bi}$ & $<1$ & 1 & 3 & 10 & 39 \\
\hline $\mathrm{Pb}$ & 13 & 14 & 12 & 27 & 63 \\
\hline$S$ & 212 & 483 & 561 & 1,709 & 2,000 \\
\hline Sn & 2 & 11 & 125 & 126 & 137 \\
\hline w & 5 & 8 & 10 & 24 & 33 \\
\hline $\mathrm{Cu}$ & 29 & 40 & 66 & 68 & 40 \\
\hline $\mathrm{Ni}$ & 71 & 91 & 61 & 41 & 11 \\
\hline $\mathrm{Zn}$ & 82 & 115 & 52 & 24 & 17 \\
\hline
\end{tabular}

Figure 6. Progressive alteration (left to right) of wacke interbeds of unit Kwcf into the white, pyritic rock seen at the Hill 1835 prospect. The data are average direct XRF compositions for 5-10 of each type: unaltered, very weak, weak, moderate, and strong. Note the progressive change in color and composition. 


\section{DESCRIPTION OF MAP UNITS}

\section{UNCONSOLIDATED DEPOSITS}

\section{Alluvial Deposits}

Qa

Qaf

Qat

QTfb

Qcl

Qcf

Qer
UNDIFFERENTIATED ALLUVIUM (Quaternary) —Chiefly moderately to well sorted, stratified, polymictic pebble, cobble, and boulder gravel, sand, and silt comprising channel and overbank deposits of generally small streams. Clasts of the local bedrock are rounded to subangular. Locally auriferous.

ALLUVIAL FAN DePosits (Quaternary) —Fan-shaped deposits of nonsorted to well sorted gravel, sand, and silt with numerous cobbles and boulders in proximal zone. In general, size of clasts decreases and degree of sorting increases downfan. Typically mixed with debris-flow deposits in proximal part of fans. Lithologies reflect bedrock of source area.

TERRACE ALLUVIUM (Quaternary) - Chiefly moderately to well sorted pebble and cobble gravels with some silty sand and local silt lenses. No longer flooded by the streams that deposited the alluvium, which is locally auriferous. Covered by 1-2 m of overbank silts and sands, locally by several meters of retransported silt and lowland loess. May include several levels. Locally subject to inundation by seasonal slope and stream icings.

BENCH AlluviUm (Quaternary to Tertiary) - Locally auriferous, oxidized alluvial gravels that are present on bedrock benches well above local streams as a result of a long and complex history of stream piracy and tectonic deformation in the Livengood area. On Livengood bench, 3-15 m of crudely bedded, moderately to well sorted, subrounded, oxidized, polymictic pebble and cobble gravels with some sand; contains organic and inorganic silt lenses up to $8 \mathrm{~m}$ long and $0.5 \mathrm{~m}$ thick, with scattered fossilized wood fragments and stumps up to $0.3 \mathrm{~m}$ in diameter. The bench gravels are $15-25 \mathrm{~m}$ above the modern drainage and are overlain by $15-40 \mathrm{~m}$ of frozen, retransported silt and lowland loess. Pollen assemblage indicates Pliocene(?) or possibly latest Miocene age (Karl and others, 1988).

\section{Colluvial Deposits}

LANDSLIDE DEPOSITS (Quaternary) - Matrix-supported silty diamicton with numerous angular to subangular pebbles, cobbles, and boulders. Slide in the vicinity of lower Amy Creek measures $1.37 \mathrm{~km}$ long by up to $1.1 \mathrm{~km}$ wide, and the 3.5-m-thick slide deposit is composed of three 0.8 - to 1.5 -m-thick, very pale brown to reddish yellow, massive, horizontal beds that could indicate a history of three failure events. The slide on the western flank of the bedrock ridge between Lucky and Goldstream creeks is deeply dissected, and the slide headwall at $\sim 530 \mathrm{~m}(\sim 1,750 \mathrm{ft})$ elevation is subdued, indicating the antiquity of the deposit (Reger and Burns, 2013).

\section{MiXed Deposits}

MiXed ColluviUm AND ALLUVIUM (Quaternary)—Primarily elongate, massive to poorly stratified, generally inorganic silt (loess) mixed with locally auriferous, sandy, angular to subangular pebble and cobble gravels with scattered boulders derived from weathered bedrock uplands. Grades downvalley into retransported silt, lowland loess, and stream terraces at the margins of lowlands. Colluvial processes $>$ fluvial processes.

RETRANSPORTED SILT AND LOWLAND LOESS (Quaternary) - Chiefly massive to laminated organic silt and silt with trace to some fine sand, lenses, and tongues of locally derived gravel, and scattered to numerous angular rock fragments (particularly in upper valleys of small, ephemeral streams). Complexly mixed with gelifluction and debris-flow deposits in upper stream drainages and primary airfall loess in lowland sites. Transitional on middle slopes with frozen loess containing considerable ground ice. Fluvial processes $>>$ colluvial processes. Lowland surfaces fairly smooth with scattered, open-system pingos and local thermokarst pits, ponds, and lakes. Erosion on slopes by ephemeral drainages produces subparallel gullies separated by linear ridges and ellipsoidal and triangular remnants that are generally shallowly frozen, except beneath well-developed aspen and birch forest on upper south-facing aspects. May be subject to seasonal stream and slope icings. Locally contains fossil remains of late Pleistocene mammals. Includes unit cf of Waythomas and others (1984). 
UPLAND Silt AND COLLUVIUM (Quaternary) — Composite unit consisting of loess (Reger and Burns, 2013) and silty colluvium (Waythomas and others, 1984). Loess occurs as a blanket, generally $<1 \mathrm{~m}$ thick, of massive, very well sorted eolian silt with thin, local, oxidized weathering profiles and traces of organic material that covers ridge crests and upper south-facing slopes. Small, frost-jacked angular rock fragments are locally present close to underlying weathered bedrock. On north-, east-, and west-facing upper and middle slopes a blanket 1.5-14 m thick of massive to laminated, very well sorted eolian silt typically contains soil horizons and organic layers. Loess is transitional on middle slopes with retransported silt and lowland loess covering lower slopes. Fine-grained colluvium occurs as reworked eolian or fluvial silt on lower slopes, locally mixed with sand and angular clasts, usually cryoturbated, frozen, organic rich, and devoid of sedimentary structures or strata that can be traced over a significant distance. Thermokarst features and patterned ground are commonly developed on the surface of the colluvial deposits.

\section{SWAMP DEPOSITS}

Qs

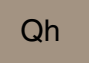

SWAMP DEPOSIT (Quaternary) —Elongate deposit of silt and organic material in drained impoundment basin behind Hess Creek dam.

\section{Manmade Deposits}

PLACER TAILINGS AND ARTIFICIAL FILLS (Quaternary) — Chiefly gravel mixed with angular to subangular rock rubble, sand, and silt in placer-mine tailings, ditches, active surface-mine pits, and borrow pits for road construction, or heterogeneous fine-grained excavated overburden and fillings of siltation ponds.

\section{BEDROCK GEOLOGIC UNITS}

\section{INTRUSIVE ROCKS}

LAMPROPHYRE DIKE (Tertiary)—Fine-grained, black, biotite- and clinopyroxene-porphyritic lamprophyre dike $1.1 \mathrm{~km}$ north of the town of Livengood. Modal composition of 7 percent clinopyroxene, 5 percent feldspar (primarily orthoclase), 4 percent biotite, $<1$ percent interstitial quartz, rare accessory apatite, iron oxide, and very-fine-grained groundmass. Contains clinopyroxene phenocrysts up to $3 \mathrm{~mm}$ long with an average diameter of $1.5 \mathrm{~mm}$. Most euhedral feldspar crystals are thinly zoned. Alignment of phenocrysts' long dimension is evidence of poorly formed flow banding. Sample contains one matted (recrystallized?) xenolith $2 \mathrm{~mm}$ by 2.5 $\mathrm{mm}$ wide of biotite and opaque minerals. Magnetic susceptibility of dike is low $(0.05-0.15$, averaging $0.10 \times$ $10^{-3} \mathrm{SI}$ [Système International]). Athey and others (2004a) report an ${ }^{40} \mathrm{Ar} /{ }^{39} \mathrm{Ar}$ biotite plateau age of $56.6 \pm 2.9$ Ma for this unit (map location A4).

SHORTY CREEK INTRUSIVE SUITE (Late Cretaceous) —White to pale green plagioclase-quartz-K-feldspar-biotite porphyry dikes and sills intruding the sedimentary rocks of the Wilber Creek unit. Phenocryst mineralogy includes 25-35 modal percent $1-2 \mathrm{~mm}$ plagioclase, 5-25 percent $0.5-5 \mathrm{~mm}$ subhedral quartz, 5 percent $1-2$ $\mathrm{mm}$ K-feldspar, and 5-10 percent 1-6 $\mathrm{mm}$ subhedral biotite. The aphanitic groundmass is dominated by intergrown quartz, K-feldspar, and sericitized plagioclase. Least-altered samples plot as granite, granodiorite, or quartz monzonite on the total alkalis vs. silica diagram of Middlemost (1985). This unit is characterized by strong alteration, including complete sericitization of plagioclase and nearly complete sericitization of biotite. Magnetic susceptibility is very low $\left(0.01-0.14\right.$, averaging $\left.0.05 \times 10^{-3} \mathrm{SI}\right)$. Biotite from this unit yields an ${ }^{40} \mathrm{Ar} /{ }^{39} \mathrm{Ar}$ plateau age of $66.6 \pm 0.5 \mathrm{Ma}$ (map location A5, this study).

Kmk MONEY KNOB INTRUSIVE SUITE (early Late Cretaceous) - Cream to light gray, porphyritic to rarely equigranular alkaline (syenite to quartz monzonite) dikes and sills centered in the Money Knob area. Average modal composition includes 60-82 percent fine-grained feldspar (proportion of orthoclase and plagioclase is dependent on rock chemistry), 0-40 percent K-feldspar phenocrysts up to $3 \mathrm{~cm}$ in diameter, 2-20 percent interstitial quartz, $0-15$ percent biotite, $0-2$ percent clinopyroxene, and trace accessory ilmenite and magnetite(?). Biotite and feldspar phenocrysts are occasionally zoned. Clinopyroxene, and biotite to a lesser degree, are preferentially altered to matted, fine-grained mixtures of carbonate, sericite, iron oxide, epidote(?), and sphene(?). Magnetic susceptibility is generally low $\left(0.00-0.37\right.$, averaging $\left.0.11 \times 10^{-3} \mathrm{SI}\right)$. 
Least-altered samples from drill core in the Money Knob resource area are biotite syenite by modal mineralogy and include equigranular, biotite, and biotite-feldspar porphyritic variants. The groundmass of least-altered samples is $50-70$ modal percent K-feldspar, $10-50$ percent biotite, $<10$ percent plagioclase, and $<10$ percent quartz (Nichols, 2013).

Dikes are affected by vein selvage to pervasive alteration. Early secondary biotite is overprinted by sericitepyrite-arsenopyrite and subsequent albite-quartz-ankerite-pyrite-arsenopyrite-stibnite. A late, low-temperature clay alteration assemblage includes kaolinite, smectite, illite, quartz, and ankerite (Nichols, 2013).

A porphyritic quartz monzonite dike yields an ${ }^{40} \mathrm{Ar} /{ }^{39} \mathrm{Ar}$ biotite plateau age of $91.7 \pm 0.4 \mathrm{Ma}$ (map location A2), and biotite from an equigranular quartz syenite dike yields an ${ }^{40} \mathrm{Ar} /{ }^{39} \mathrm{Ar}$ plateau age of $93.2 \pm 0.4 \mathrm{Ma}$ (map location A3; Athey and others, 2004a). Nichols (2013) reports a concordant U-Pb zircon age of $92.04 \pm 0.14$ Ma from biotite syenite (table 3; map location U1).

Kcrp CASCADEN RIDGE PLUTON (Cretaceous?)—Fine- to medium-grained, seriate to locally porphyritic pluton and small intrusions of syenite to quartz monzonite composition (Griesel and others, 2010). Mineralogy averages 40-90 modal percent $0.25-3 \mathrm{~mm}$ subhedral K-feldspars, with local euhedral K-feldspar phenocrysts up to 15 $\mathrm{mm}, 5-50$ percent plagioclase $0.25-3 \mathrm{~mm}, 0-8$ percent $1-2 \mathrm{~mm}$ subhedral quartz, and 5-10 percent $0.25-4$ $\mathrm{mm}$ hornblende completely replaced by rutile, sphene, and carbonate. Magnetic susceptibility is low to moderate $\left(0.0-0.47\right.$, averaging $\left.0.151 \times 10^{-3} \mathrm{SI}\right)$.

The Cretaceous? age of this unit is inferred based on its alkaline composition and its geochemical similarity to unit Kmk.

FELSIC TO INTERMEDIATE DIKES AND SILLS (undifferentiated) (Cretaceous?)—Variably altered and weathered felsic to intermediate intrusive rocks not assigned to any of the above units.

Olive CReek Pluton (Devonian?) - Fine-grained, grayish green, K-feldspar-porphyritic felsic intrusion at the intersection of Olive Creek and the old Elliott Highway. Contains K-feldspar phenocrysts (3-4 mm long) in an aphanitic to very-fine-grained, occasionally flow-banded matrix. Magnetic susceptibility from one location is low $\left(0.00-0.17\right.$, averaging $\left.0.10 \times 10^{-3} \mathrm{SI}\right)$. Locally brecciated, clay altered, and containing phenocrysts (K-feldspar?) partially replaced by quartz and sericite. Locally limonite and malachite stained.

The Devonian age is inferred based on geochemical similarity to volcanic rocks in the Cascaden Ridge unit (map unit Dcv), which are constrained by fossils in the adjacent sedimentary rocks.

\section{Wilber Creek Unit}

Kwcf

WiLBER CREeK FLYSCH (Cretaceous; Albian) - Mixed sedimentary unit consisting of finely laminated to interbedded shale, siltstone, and wacke, and interpreted as deposited in a turbidite sequence. Shale and siltstone beds are typically dark-gray to black, and wacke is medium-gray to olive green. Weathered portions are weakly to strongly iron-oxide stained. Beds in the unit range from $0.1-10 \mathrm{~cm}$ thick and are typically upright, as evidenced by cross beds and graded bedding. Thicker beds of shale and wacke that cannot be traced at map scale are also included in this unit. Magnetic susceptibility is low to moderate $\left(0.0-2.16\right.$, averaging $\left.0.17 \times 10^{-3} \mathrm{SI}\right)$ with high values associated with highly altered rocks of the Hill 1835 area.

Poor to well-developed parting parallel to bedding is common throughout. A moderately spaced cleavage is parallel, oblique, and perpendicular to bedding and interpreted as axial planar to map-scale folding.

The Albian age of the Wilber Creek units is based on the presence of the ammonite Paragastroplites flexicostatus in the Livengood B-6 Quadrangle (Weber and others, 1992).

WiLBer CREeK CONGLOMERATE (Cretaceous; Albian) —Well indurated matrix- to clast-supported conglomerate forms blocky outcrops along ridges and hilltops. It is poorly sorted and commonly interbedded with coarse-grained, angular wacke. Tan, dark- to light-gray, black, and greenish black matrix comprises 30-70 percent of the rock and includes immature, poorly sorted, lithic-rich wacke, quartz-rich fine- to mediumgrained sandstone, and siliceous siltstone.

Clasts range from rounded to subangular, but are mostly subrounded, and range in size from 0.5 to $15 \mathrm{~cm}$ long, averaging $\sim 2 \mathrm{~cm}$. Field observations of clast lithologies noted that a majority of the clasts are felsic to 
intermediate igneous rocks, quartzites, and sandstones, with minor foliated metamorphic rocks and rip-up clasts of shale and turbidites.

Basal contact with shales or sandstones is sharp and erosional, and bedding is typically unrecognizable to massive. Magnetic susceptibility is low $\left(0.10-0.58\right.$, averaging $\left.0.26 \times 10^{-3} \mathrm{SI}\right)$.

The conglomerate is typically resistant to the penetrative compressional deformation, such as folding and associated axial planar cleavage, that affects the fine-grained units. Localities with siltstone matrix exhibit a high-strain flattening fabric in the matrix parallel to micaceous (muscovite \pm biotite \pm chlorite) foliation. The unit displays jointing; however, penetrative jointing that cuts the fine-grained units typically does not continue into the conglomerate.

Kwcs Wilber CReEk Shale AND Siltstone (Cretaceous; Albian)—Mixed sedimentary unit composed of shale and siltstone. Siltstone is dominantly dark-gray to black, locally greenish gray. Grains are moderately to well sorted, subangular to subrounded, and dominated by approximately equal amounts of albite $\left(\mathrm{An}_{0-10}\right)$ and quartz, with lesser lithics and minor clinopyroxene and amphiboles. The lithology is thinly bedded to massive with a welldeveloped parting.

The shale member is dark-gray to black, fissile, and finely laminated, with beds ranging from 0.1 to $10 \mathrm{~cm}$. It is well sorted, grain-supported, and composed of subangular to subrounded albite, quartz, micas (chlorite \pm biotite), with minor hornblende, epidote, and zircon. Shale is locally metamorphosed to slate or phyllite and often exhibits crenulation and cleavage development. Magnetic susceptibility is low to moderate (0.06-11.00, averaging $0.50 \times 10^{-3} \mathrm{SI}$ ) with high values associated with highly altered rocks of the Hill 1835 area.

Cleavage, interpreted as axial-planar to map-scale folding, is defined by biotite and/or muscovite growth concordant and discordant to bedding. Cleavage commonly intersects bedding at moderate to high angles, resulting in development of pencils $0.5-2 \mathrm{~cm}$ in diameter and up to $30 \mathrm{~cm}$ long. In thin section, the unit has a welldeveloped shear fabric defined by anastomosing micas wrapping quartz and plagioclase porphyroclasts.

\section{Metamorphosed Sedimentary and Igneous Rocks}

\section{SOUTH OF VICTORIA CREEK FAULT}

\section{CASCADEN RIDGe UNIT}

Cascaden Ridge Sandstone, Shale, and Conglomerate (Middle Devonian)—Mixed sedimentary unit composed of interbedded sandstone and shale $>>$ siltstone/mudstone/argillite $>$ conglomerate $>$ wacke. Sandstone is medium- to dark-brownish gray and light-grayish yellow. Fine- to medium-grained and lesser coarsegrained to small pebble sandstone contains rounded to angular clasts of chert, quartz, carbon, opaque minerals, and lesser plagioclase $\left(\mathrm{An}_{11-18}\right)$, chlorite, and lithic fragments. Sandstone is clast supported to slightly matrix supported. Cements include variable amounts of carbonate, limonite, and mud (recrystallized to fine-grained white mica). Carbonate cement is partially leached out of most surface samples. Sandstone with high carbonate content verges on sandy limestone, and several samples contain crinoids. Sandstone increases in grain size to clast-supported, small pebble conglomerate. Sandstone beds frequently fine upward into medium-gray to black, fissile, laminated shale with planar to rarely crenulated cleavage. Rare fining-upward sequences were identified, indicating beds are typically upright.

Other sedimentary rocks in this unit include very-fine- to minor medium-grained, hard, blocky, foliated, nonfissile, gray-black siltstone, mudstone, and argillite, which are composed of carbon, quartz, sericite, carbonate, chert, limonite, diagenetic pyrite, and magnetite. Conglomerate in the Cascaden Ridge unit contains subrounded to angular clasts up to $1.5 \mathrm{~cm}$ in diameter of chert, mudstone, sandstone, and felsic- to intermediatecomposition igneous rocks (feldspar with $\approx \mathrm{An}_{7-37}$ ). Clasts are cemented by iron oxide, carbonate, quartz, and trace mud (recrystallized to white mica). Magnetic susceptibility for the unit as a whole is generally low ( 0.00 1.19 , averaging $0.14 \times 10^{-3} \mathrm{SI}$ ), with higher values associated with argillite layers.

Rare, pale- to dark-green, massive, coarse- to fine-grained wacke contains subrounded to angular clasts of chert, quartz, albite $\left(\mathrm{An}_{4-10}\right)$, chlorite, opaque minerals, K-feldspar, and lithic fragments (carbonate, chert + carbonate, clastic sedimentary rocks). Clasts are cemented by iron oxide, carbonate, and mud (recrystallized to white mica). Magnetic susceptibility is low $\left(0.18-0.33\right.$, averaging $\left.0.26 \times 10^{-3} \mathrm{SI}\right)$. 
Based on a mineral assemblage of white mica + chlorite \pm albite, this unit exhibits a maximum metamorphic grade of lower greenschist facies.

A fossil locality in the map area indicates a Middle Devonian age for this unit and associated units Dcl, Dcu, and Dcv (Blodgett, 1992; see table 2 and map location F1).

Cascaden Ridge Sandstone, Siltstone, and Conglomerate (Middle Devonian)—The uppermost subunit of Dc, defined by exploration drilling in the Money Knob resource area by Klipfel and others (2009) as thick beds of the siltstone, sandstone, conglomerate, shale, and limestone facies described above. The subunit overlies unit Dcv on a depositional contact; the upper contact is structural and the total thickness is unknown. The upper sediments are distinguished from the lower sediments by coarser grain size and thicker beds. Magnetic susceptibility for the unit as a whole is generally low $\left(0.00-1.60\right.$, averaging $\left.0.12 \times 10^{-3} \mathrm{SI}\right)$.

Cascaden Ridge Peralkaline Rhyolite Flows, Breccia, and Lithic Tuff (Middle Devonian)—A twopart sequence consisting of a porphyritic basal flow unit characterized by amygdules and flow breccia textures, and an upper unit of crystal lithic tuff. Where the volcanics outcrop in the Ruth Creek drainage they are lightto dark-gray, greenish gray, and white with an aphanitic, sucrosic, or locally flow-banded texture. Porphyritic samples have up to 8 percent feldspar phenocrysts as large as $8 \mathrm{~mm}$ in length. Porphyritic samples from the Cascaden Ridge unit typically contain 1-3 percent each of 1-2 mm subhedral K-feldspar and quartz phenocrysts in a dark-gray aphanitic groundmass. Magnetic susceptibility for the unit as a whole is generally low $\left(0.00-1.0\right.$, averaging $\left.0.10 \times 10^{-3} \mathrm{SI}\right)$.

Altered volcanic rocks belonging to this unit were previously mapped as the Ruth Creek and Olive Creek plutons by Athey and Craw (2004). Subsequent exploration drilling at Money Knob showed that these rocks have volcanic textures and comprise a stratiform layer approximately 10-75 m thick (Klipfel and others, 2009). The unit is characterized as peralkaline rhyolite on the basis of its high $\mathrm{Zr}$ and high $\mathrm{Zr}: \mathrm{TiO}_{2}$ ratios on the immobile trace-element discrimination diagram of Winchester and Floyd (1977).

Dcl Cascaden Ridge Shale to Fine Sandstone (Middle Devonian)—The stratigraphically lowest subdivision of unit Dc, dominated by the shale to fine sandstone facies described above. This subunit is distinguished from unit Dcu by its finer grain size, higher abundance of carbonaceous material, and by trace-element geochemistry (Klipfel and others, 2009).

\section{Amy Creek UnIT}

Amy Creek Dolostone, Siliceous Dolostone, And Limestone (lower Paleozoic to Neoproterozoic)White to light-gray, buff, pale-yellow, and orange-brown dolostone, siliceous dolostone, and rare limestone variably replaced by quartz. Quartz occurs as veins and web-like structures as well as massive replacement within carbonate. $\mathrm{SiO}_{2}$ ranges from less than 1 percent to $>50$ percent (Athey and others, 2004c). Unit varies from almost pure dolomite (17.75-21.12 percent $\mathrm{MgO}$; pure dolomite contains 21.7 percent $\mathrm{MgO}$ ) to rare, almost pure limestone (54.1 percent $\mathrm{CaO}$; pure limestone contains 56 percent $\mathrm{CaO}$; Athey and others, 2004c). Rarely interbedded with siliceous mudstone and chert (IPZZmc) layers that are approximately $>90 \mathrm{~m}$ thick. Occasionally contains bands, fractures, and interlaminations of black carbon and silica, possibly an indication of proximity to a contact with IRZZmc. Weathered surfaces occasionally exhibit popcorn-like, vuggy, and rough textures depending on the amount of carbonate leaching. Commonly crops out as mounded rubble. Magnetic susceptibility is very low $\left(0.00-7.0\right.$, averaging $\left.0.07 \times 10^{-3} \mathrm{SI}\right)$. Commonly brecciated with a quartz matrix and crosscut by $<1$-mm- to 3-cm-thick, gray, translucent to sucrosic quartz veins and up to 5-cm-thick calcite veins. Occasional limonite stains on fracture surfaces. Samples of lime mudstone (map locations F15, F16, and F17; table 2), dolomitic wackestone (map location F18; table 2), and dolomudstone (map location F19; table 2) contain no conodonts or visible macrofossils. Three samples contain algal biolithites with no biostratigraphic significance (F15, F16, and F19; table 2). Equivalent to dolostone portion of unit SZa (Weber and others, 1992). A total thickness of $274 \mathrm{~m}$ for this unit was estimated from a schematic cross section through the map area. A homogeneous $\sim 122$-m-thick layer of IPZZd lies above IPZZmc and is capped by a $>152$-m-thick, mixed layer of the Amy Creek units.

The presence of sponge spicules (map location F14; table 2) gives maximum age of Neoproterozoic for this unit; the minimum age is constrained by unconformably overlying sediments as old as Middle Devonian (Weber and others, 1992). See Discussion of Geology section of this report for a more complete discussion. 
Amy CReek Metabasalt (lower Paleozoic to Neoproterozoic)-Aphanitic metabasalt, greenstone, finegrained microgabbro, and trace diabase flows and (or) sills. Occurs as laterally continuous horizons interlayered with Amy Creek dolostone and limestone (IRZd) and Amy Creek siliceous mudstone and chert (IPZmc). Metabasalt is dark-green or greenish brown to black and when weathered is brown, black, orange, or red. Average modal composition is approximately $35-70$ percent plagioclase $\left(\approx \mathrm{An}_{35}\right), 0-70$ percent clinopyroxene, 5-35 percent magnetite, $0-10$ percent orthopyroxene, and 0-65 percent altered glass(?). Typically massive and blocky in outcrop and rarely slightly foliated or slightly brecciated. Outcrops in the West Fork Tolovana River valley are intensely brecciated with east-northeast-trending strike-slip fault planes and interpreted southeast-trending riedel shear planes. Magnetic susceptibility is generally very high, but significantly variable in the outcrop $\left(0.19-115.0 \times 10^{-3} \mathrm{SI}\right.$, averaging $\left.12.63 \times 10^{-3} \mathrm{SI}\right)$. Protolith had a CIPW normative basaltic composition with a within-plate trace-element-indicated tectonic signature (Athey and others, 2004c). Relict amygdules are common and are frequently filled with carbonate \pm chlorite. Degree of alteration varies. Alteration minerals include chlorite, carbonate, prehnite, clinozoisite, epidote, sericite, pumpellyite, and iron oxide. Unit is metamorphosed to prehnite-pumpellyite facies. Fractures are coated with chlorite and commonly stained with iron- and manganese-oxide, and rocks are crosscut by rare 1-3 $\mathrm{mm}$ carbonate veins. Equivalent to greenstone portion of unit SZa (Weber and others, 1992). Regionally, metabasalt layers are at least $100 \mathrm{~m}$ thick (Weber and others, 1992). Our estimated thickness from a schematic cross section through the map area is approximately $30-45 \mathrm{~m}$.

The age of this unit is constrained by its association with the other Amy Creek units.

Amy CReek Siliceous Mudstone And Chert (lower Paleozoic to Neoproterozoic)-Mixed sedimentary unit primarily containing siliceous mudstone $>$ chert $>$ conglomerate/breccia $>$ argillite, sandstone, siltstone, and shale. Mudstone, which breaks along hackly fractures instead of conchoidal surfaces, is the largest component of this unit and is intermediate in composition between chert and the other fine- to coarse-grained sedimentary rocks. Black and rare dark- to pale-gray siliceous mudstone weathers orange, brown, and red. Manganese- and iron-oxide staining variably present and locally intense. Mudstone is locally brecciated and cut by $1-5-\mathrm{mm}-$ thick, vuggy, milky quartz \pm limonite \pm carbonate veins.

Chert is variegated, mottled, and rarely color banded. Colors include black, dark- to light-gray, grayish green, yellowish brown, and maroon. Float is massive and blocky. Chert is homogeneous, occasionally laminated with few white clay partings, and in one location contains nodules of clay $1.3 \mathrm{~cm}$ in diameter. Occurrences of intense, milky white quartz veins averaging $0.5-1 \mathrm{~mm}$ thick with rare veins up to $1 \mathrm{~cm}$ thick are common along the West Fork Tolovana River, with occasional occurrences elsewhere. Chert weathers brown, orange, red, yellow, and white, and exhibits iron-oxide \pm manganese-oxide on fractures, rare brecciated and jasperoidal quartz, and limonite after rare 1-2 percent disseminated pyrite. Chert is rarely interbedded with mudstone, sandstone, siltstone, and tuff(?) on a millimeter to $10 \mathrm{~cm}$ scale.

Black, gray, tan, and white clast-supported conglomerate and breccia contain subrounded to angular, flattened clasts of chert, mudstone, and quartz $2 \mathrm{~mm}$ to $2 \mathrm{~cm}$ in diameter. Gray, green-gray, and tan, interbedded sandstone, wacke, siltstone, and shale contain variable amounts of sericite, quartz, carbon, lithic fragments (chert and glassy tuff), plagioclase, chlorite, and opaque minerals. The vuggy, porous, and friable matrix is composed of silica + limonite \pm carbonate \pm opaque minerals \pm carbon \pm chalcedony \pm trace mud (recrystallized to veryfine-grained white mica). Very-fine- to fine-grained, fissile, black argillite is locally interlayered with the other sedimentary rocks. The weathered orange, brown, and red sedimentary rocks are occasionally iron-oxidestained, quartz veined, and contain rare disseminated pyrite.

Magnetic susceptibility for this unit is generally very low $\left(0.00-0.62\right.$, averaging $\left.0.03 \times 10^{-3} \mathrm{SI}\right)(0.01-0.64$, averaging $0.02 \times 10^{-3} \mathrm{SI}$ ), but rare argillite layers have higher magnetic susceptibilities up to $0.63 \times 10^{-3} \mathrm{SI}$. Unit equivalent to chert and other clastic rocks from unit SZa of Weber and others (1992). Unit comprises a >884-m-thick section at the base of the Amy Creek unit. Lithologies of this unit are also interlayered with the dolostone and metabasalt above the main dolostone and limestone (IPzZd) section.

The age of this unit is constrained by its association with the other Amy Creek units. Detrital zircons (table 3; map location DZ1; Appendix C) from a conglomerate interpreted as part of this unit support an early Silurian maximum depositional age. 


\section{Lost Creek UnIt}
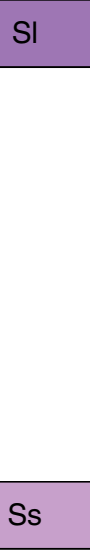
Medium- to dark-gray, grayish green, and tan sandstone with angular to rounded clasts of chert, quartz, shale,
argillite, plagioclase, and rare opaque grains. Sandstone is cemented with carbonate, iron oxide, mud (recrystallized to white mica), carbon, and black to dark-gray silica. While mostly very-fine-grained sand to coarse granule (1-3 mm sand-sized), the clast-supported to slightly matrix-supported sandstone contains clasts up to $2 \mathrm{~cm}$ in diameter. Bedding is not locally visible in the sandstone. Although the sandstone is finer grained and more sorted, the sandstone and conglomerate have very similar clast compositions, and both weather to an orange color.

Gray and tan, matrix-supported, basal conglomerate contains subrounded clasts $<5 \mathrm{~cm}$ in diameter of multicolored chert, argillite, shale, limestone (crinoid cast; map location F8; table 2), and tuff (plagioclase, quartz, opaque minerals, and chlorite). Conglomerate is cemented by iron oxide and silica. There is a very-fine- to very-coarse-grained, poorly sorted sandstone component in the conglomerate.

Pale-grayish green, dark-gray, and black limey shale, argillite, and siltstone weather to black and orange and are commonly interbedded with sandstone. Sedimentary rocks are foliated and blocky fracturing to fissile. Fine-grained sedimentary rocks contain clasts of chert, fossils (crinoids; map location F9; table 2), sericite, feldspar, chlorite, hornblende, and trace zircon. Cemented by iron oxide, carbonate, and quartz.

Green wacke has a similar clast composition to the shale, argillite, and siltstone but contains a greater amount of volcanic lithic fragments. Fine- to medium-grained, clast-supported wacke contains chert, quartz, biotite, opaque minerals, sedimentary and volcanic lithics, chlorite, hornblende, plagioclase, and fossils. Wacke is cemented with a matrix of up to 70 percent carbonate, carbon, iron oxide, and mud (partially recrystallized to white mica).

Sedimentary rocks are crosscut by carbonate veins and, less frequently, crystalline quartz veins. Unit is equivalent to the lower clastic portion of the Lost Creek limestone (unit SDI; Weber and others, 1992). A $60 \mathrm{~m}$ thickness of clastic sedimentary rocks was proposed by Chapman and others (1980). Interpretation of a schematic cross section developed from our work suggests a thickness of $>92 \mathrm{~m}$. Magnetic susceptibility for the whole unit is generally low $\left(0.00-0.36\right.$, average $\left.0.07 \times 10^{-3} \mathrm{SI}\right)$.

\section{LIVENGOOD DOME UNIT}

LIVENGOOD DOME CHERT (Ordovician) - Massive, variegated chert with minor argillite/siltstone $>>$ sandstone/wacke $>$ breccia/conglomerate $>$ rare limestone. Chert colors include light- to dark-gray, bluish gray, white, orange, red, tan, greenish blue, and black. Occasionally mottled. Commonly rhythmically bedded or color banded on a scale of $<0.1 \mathrm{~mm}$ to $3 \mathrm{~cm}$ and sometimes up to $20 \mathrm{~cm}$. Fine lamellae of clay locally define bedding. The unit fractures readily and is commonly brecciated and filled with abundant calcite cement and/or quartz veining.

Siltstone, claystone, mudstone, shale, and argillite are commonly interbedded with and transition into chert; 25 -cm-thick beds of very-fine- to fine-grained argillite are more commonly interlayered with chert than with other sedimentary rocks. Textures range from hard, cherty, and blocky to platy to soft and fissile, depending on the quartz and clay content of the rock. Fine-grained clastic rocks are commonly color banded; colors 
include maroon, gray, orange, red, medium- to pale-green, white, black, tan, and olive green. A sample of mudstone contains no visible macrofossils or graptolites (map location F10; table 2). Another sample of friable siltstone potentially contains sponge spicules (map location F11; table 2). The age of this unit is established regionally by Late Ordovician graptolites and early Middle Ordovician conodonts (Weber and others, 1994).

Dark-brown, tan, medium- to dark-gray, and grayish green sandstone and wacke contain angular to subrounded clasts of chert, quartz, argillite, chalcedony, plagioclase, sericite, chlorite, rare crystal tuff, opaque minerals, and zircon. Wacke is cemented by carbon, carbonate, quartz, mud, and limonite. Locally, bedding is apparent. Very-fine- to fine-grained and minor coarse-grained to granule sandstone and wacke are almost matrix supported. Sandstone commonly transitions into conglomerate and breccia.

Magnetic susceptibility for the unit as a whole is very low $\left(0.00-0.64\right.$, averaging $\left.0.03 \times 10^{-3} \mathrm{SI}\right)$, but rare siltstone and wacke layers have higher magnetic susceptibilities up to $0.64 \times 10^{-3}$ SI. Unit contains rare to locally abundant, randomly oriented, milky white quartz veins $<0.1-3 \mathrm{~mm}$ thick, and rare local areas with black, possibly iron- or manganese-oxide-filled veins. Weak limonite on fractures and occasional manganeseoxide staining.

\section{Cambrian Mafic and Ultramafic Assemblage}

GREENSTONE (lower Cambrian) - Mixed unit composed primarily of greenstone $>>$ volcaniclastic rocks $>$ minor lenses of metagabbro, and locally abundant metabasalt. Aphanitic to fine-grained, massive greenstone is composed of plagioclase $\left(\approx \mathrm{An}_{27-32}\right)$, hornblende, clinopyroxene (altering to hornblende), possible iddingsite and serpentine after olivine, and devitrified glass. Greenstone is pale- to dark-green, grayish green, black, and brown. Weathered black and orange greenstone is commonly altered to sucrosic mixture of quartz + clinozoisite + carbonate + chlorite + opaque \pm epidote \pm actinolite \pm sericite \pm albite. Forms large, blocky boulders and outcrops.

Clast-supported agglomerate with angular to subrounded clasts $<1 \mathrm{~mm}$ to $10 \mathrm{~cm}$ in diameter reveal their agglomeratic texture on weathered surfaces. Clasts include basaltic tuff, gabbro, and altered serpentinite. Grain size and texture of clasts varies greatly. Unit frequently is penetratively deformed. Foliated/sheared bands break into sheets $0.5 \mathrm{~cm}$ to $1 \mathrm{~m}$ thick. Crosscut by 2 -mm-thick veins of chlorite + quartz + carbonate \pm albite \pm veryfine-grained sericite. Iron- and manganese-oxide staining is common. Alteration includes trace sulfide, limonite-filled vugs, and trace malachite.

Also contains equigranular, very-fine- to coarse-grained metagabbro lenses with an average modal composition of 40-70 percent plagioclase, 30-60 percent clinopyroxene (some exsolving orthopyroxene), 0-10 percent hornblende, and opaque minerals. Secondary minerals include epidote, sericite, scapolite, chlorite, and trace pyrite. Metagabbro occurring within the greenstone unit appears more propylitically altered than that from within the metagabbro unit itself. Glassy-, porphyritic-, and diabasic-textured basalt also occurs in the greenstone. Fairly unaltered basalt contains elongate needles of plagioclase and clinopyroxene in a groundmass of devitrified glass, which has been altered to carbonate, chlorite, and iron oxide. Magnetic susceptibility is generally low to moderate $\left(0.03-27.50\right.$, averaging $\left.0.80 \times 10^{-3} \mathrm{SI}\right)$.

This unit is assigned to the early Cambrian based on its association with early Cambrian metagabbro (unit €mg).

MetagabBro (early Cambrian) —Primarily massive, blocky, homogeneous metagabbro with rare, massive, equigranular, very-fine- to fine-grained greenstone. Metagabbro is green, white, dark-gray, and black. Equigranular, fine-grained and minor medium-grained metagabbro has an average modal composition of about 35-80 percent mafic minerals (hornblende $>$ clinopyroxene) and 20-65 percent andesine $\left(\mathrm{An}_{35}\right)$. Occasional coarse-grained metagabbro with plagioclase phenocrysts up to $1 \mathrm{~cm}$ long. Multiple intrusions of gabbro presumably account for observed textural and compositional variability. Magnetic susceptibility is low to moderate with some anomalously high values $\left(0.05-60.00\right.$, averaging $\left.0.87 \times 10^{-3} \mathrm{SI}\right)$. Alteration mineralogy consists of chlorite, epidote, carbonate, sphene, opaque minerals, and clinozoisite. Metagabbro is crosscut by carbonate, chlorite, and quartz veins and contains local disseminated chalcopyrite(?) and pyrite. The layered metagabbro (Elg of Athey and others, 2004b) is locally present throughout Cascaden Ridge, but too sparse to be mapped separately and is therefore included in the €mg. Layered metagabbro is defined by alternating, equigranular 
bands of plagioclase and clinopyroxene in varying modal proportions and having flattened, elongate crystals up to $0.5 \mathrm{~cm}$ in diameter; layers average $2-3 \mathrm{~mm}$ thick.

Hornblende from this unit yields an ${ }^{40} \mathrm{Ar} /{ }^{39} \mathrm{Ar}$ plateau age of $535.3 \pm 2.7 \mathrm{Ma}$ (Athey and others, 2004a).

SERPENTINITE, MEtAGABBRO, AND GREEnstone (early Cambrian)—Recognized as a composite unit primarily containing serpentinite and minor lenses of altered metagabbro, greenstone, and mylonitic greenstone. Hard, massive, waxy, aphanitic, green and black serpentinite with anastamosing serpentine veins. Mineral composition of antigorite, minor chrysotile, and magnetite. Occasionally fissile, sheared, and folded and usually altered to quartz-carbonate listwaenite (or listwänite). Serpentinite is commonly found in local thrust fault zones, apparently acting as a slide-plane between faulted plates. Altered serpentinite is colored orange, white, brown, pale-grayish brown, blue, and pale-green. Alteration mineralogy includes quartz, talc, magnesite, chlorite, fuchsite/mariposite, brucite, iron oxide, and manganese oxide. Silica occurs in many forms: Milky, massive, drusy, vuggy, opalescent, botryoidal, chalcedony, breccia matrix, veins, and replacement. Occasionally pyrite, rare pyrrhotite(?), and rare malachite are found with the alteration. Alteration is reported to be locally goldbearing (Saunders, 1955).

Serpentinite unit also contains fine- to lesser medium-grained, equigranular, green and white metagabbro composed of plagioclase (occasionally poikilitic), hornblende, clinopyroxene (altering to hornblende), and opaque minerals. Average modal composition is about 50 percent plagioclase and 50 percent mafic minerals. Rare metabasalt contains clinopyroxene phenocrysts. Metagabbro and metabasalt form blocky, massive outcrops. Associated minor, mottled, medium- and dark-green and white greenstone is blocky, aphanitic, and granular. On Cascaden Ridge small outcrops of light-green conchoidal, aphanitic greenstone are mylonitic. Metagabbro and greenstone are frequently brecciated and altered to epidote, chlorite, carbonate, clinozoisite, iron oxide, and sphene, and contain minor milky to clear quartz-carbonate veins and rare malachite and chrysocolla in fractures.

Magnetic susceptibility is extremely variable $\left(0.06-74.6\right.$, averaging $\left.26.04 \times 10^{-3} \mathrm{SI}\right)$, in line with the primary compositional variability of the rocks and the presence of silica-carbonate alteration. Very high magnetic susceptibility values are due to secondary magnetite produced during serpentinization. Prehnite-pumpellyite facies metamorphic grade is indicated by a secondary mineral assemblage that includes chlorite, epidote, pumpellyite, relict augite, actinolite(?), and rare albite. X-ray diffraction studies indicate prehnite is also present (Foster, 1966).

This unit is assigned to the early Cambrian based on its association with early Cambrian metagabbro (unit €mg).

MUdSTONE AND CHERT (lower Cambrian) - Mixed sedimentary unit composed of chert, mudstone $>>$ conglomerate. Gray to black chert is commonly interlayered with gray to black variably silicified cherty siltstone and cherty shale. Minor fine-grained conglomerate is occasionally found. Magnetic susceptibility for this unit is generally very low $\left(0.00-0.30\right.$, averaging $\left.0.05 \times 10^{-3} \mathrm{SI}\right)$.

These sediments were originally recognized by DGGS in 2003 and interpreted as belonging to the Amy Creek unit (Athey and others, 2004b); however, subsequent drilling by ITH reveals that these units are complexly interleaved with the Cambrian mafic and ultramafic package, and they have been reinterpreted as sedimentary rocks associated with the mafic to ultramafic suite.

\section{WICKERSHAM UNIT}

WiCKERSHAM LIMESTONE (lower Cambrian?) - Very-fine- to medium-grained, medium- to dark-gray, sparry, recrystallized limestone with abundant white calcite veins up to $1 \mathrm{~cm}$ thick. Forms massive and blocky outcrops, sometimes with visible bedding. Variably sandy with rounded to subrounded grains and occasional dolomite rhombs and peloids. Carbonate grains average about $0.02-0.5 \mathrm{~mm}$ in diameter. Composition includes very minor mud, carbon, quartz, and iron oxide. Locally foliated with white shale partings; contains a few ironoxide-filled fractures. Three samples of recrystallized lime mudstone contain no conodonts or visible macrofossils (map locations F20, F21, and F22; table 2). Age of unit is unknown; however, it presumably lies stratigraphically above the lower Cambrian(?) to upper Proterozoic Wickersham shale (unit €Zwa) and is tentatively 
€Zwa Wickersham Shale (lower Cambrian? to upper Proterozoic)-Maroon shale. Exposed in Willow Creek 0.8 $\mathrm{km}$ north of the map area. Unit occurs in low-lying, loess-covered hills and swamps. Magnetic susceptibility is low $\left(0.10-0.20\right.$, averaging $\left.0.15 \times 10^{-3} \mathrm{SI}\right)$. Likely correlates with Wickersham unit $€ Z$ wa of Weber and others (1992), which contains maroon and green argillite, grit (sandstone with bimodal grain size), quartzite, siltstone, graywacke, and phyllite. Age of unit is unknown, but is tentatively assigned an lower Cambrian(?) to upper Proterozoic age because of its stratigraphic position above the Wickersham unit $€ Z$ wg (Weber and others, 1992, 1994).

\section{NORTH OF VICTORIA CREEK FAULT}

kg RAMPART GABBRO, QUARTZ GABBRO, AND MINOR CHERT (Triassic) - Coarse- to lesser medium-grained, equigranular, pale- to dark-green and white gabbro to quartz gabbro. Average modal composition approximately 35-60 percent clinopyroxene, 35-50 percent labradorite $\sim \mathrm{An}_{55}$ ), 0-30 percent hornblende (some with pyroxene cores), 0-20 percent biotite, $0-10$ percent quartz, 3 percent skeletal magnetite, and accessory zircon. Secondary minerals include actinolite, sericite, stilpnomelane, albite, lawsonite(?), chlorite, zoisite, and iron oxide, which indicate a maximum metamorphic grade of lower greenschist facies. Unit includes white, lightto medium-gray, and tan chert with iron-oxide-coated fractures. Magnetic susceptibility for the unit as a whole is moderate $\left(0.16-0.74\right.$, averaging $\left.0.38 \times 10^{-3} \mathrm{SI}\right)$.

The age of this unit is constrained by Triassic radiolaria found in interlayered chert from the Livengood C-5 Quadrangle (Weber and others, 1994). Hornblende from gabbro that intrudes Rampart Group volcanic rocks yields a minimum K-Ar age of $210 \pm 6$ Ma (Brosgé and others, 1969; age recalculated by Wilson and others [1998]).

kDs SAndstone, Shale, AND CHERT (Triassic to Devonian)-Mixed sedimentary unit containing sandstone/quartzite $>$ shale/siltstone $>$ chert. Clast-supported, possibly reworked, bimodal(?) sandstone is composed of fine-grained, rounded to subangular grains of quartz averaging $0.02 \mathrm{~mm}$ in diameter and highly altered, very-fine-grained white mica + quartz pseudomorphs of original sedimentary clasts $(<1 \mathrm{~mm}$ in diameter). Cemented by iron oxide and mud (recrystallized to white mica). Sandstone is pale-greenish gray, orange, tan, and brown. Lesser gray shale, gray siltstone, and white, light-gray, and tan chert. Iron oxide and pyrite locally coat fractures. Magnetic susceptibility is low (0.04-0.08, averaging $\left.0.07 \times 10^{-3} \mathrm{SI}\right)$.

The mixed sedimentary unit (KDs) may be equivalent to either the Triassic sedimentary rocks of the Rampart Group to the north (unit kMrs; Weber and others, 1992) or the Permian to Devonian sedimentary rocks to the south (PDms; Weber and others, 1992).

SHALE (Permian? to Devonian)—Green, tan, and red shale and mudstone. Fissile with a few quartz veins and trace iron oxide. Petrographic analysis indicates poorly formed S-C fabric (Lister and Snoke, 1984) and a composition of sericite, rounded quartz, iron oxide, and trace chlorite. Magnetic susceptibility of the only sample measured is low: $0.09 \times 10^{-3} \mathrm{SI}$.

The age of the unit is based on Devonian conodonts from the Livengood C-3 Quadrangle $15.2 \mathrm{~km}$ northeast of the map area and late Paleozoic (early Permian?) echinoderm debris from the Livengood C-3 Quadrangle 7.6 $\mathrm{km}$ north of the map area (Weber and others, 1994). 


\section{ACKNOWLEDGMENTS}

This project is part of the Alaska Airborne Geophysical/ Geological Mineral Inventory Program funded by the Alaska State Legislature and managed by State of Alaska, Department of Natural Resources (DNR), Division of Geological \& Geophysical Surveys (DGGS). Partial funding for the 2003 geologic mapping was also provided by the U.S. Geological Survey, National Cooperative Geologic Mapping Program, under STATEMAP award number 03HQAG0055. The views and conclusions contained in this document are those of the authors and should not be interpreted as necessarily representing the official policies, either expressed or implied, of the U.S. Government.

The following people are recognized for their various contributions to this map: C.C. Puchner, M.R. Hayes, and R.E. Meyers of International Tower Hill Mines, Ltd. (data, interpretations, access to drill core, and geological discussions); C.J. Freeman and Avalon Development Corp. (data and geologic discussions); D.C. Bradley and J.V. Jones of U.S. Geological Survey and P.B. O'Sullivan and R.A. Donelick of Apatite to Zircon Inc. (detrital zircon geochronology); J.N. Christensen of Lawrence Berkeley National Laboratory (attempted Sm-Nd geochronology of the Amy Creek metabasite); F.R. Weber, R.B. Blodgett, J.A. Dumoulin (geologic discussions); R.J. Newberry (gold microprobe study); W.R. Bolton (hydrogeologic discussions); J.G. Clough and R.R. Reifenstuhl (sedimentary rock discussions); P.E. Gallagher, S.A. Hicks, L.A. Staft, C.L. Browne, A. Africa, and T.B. Fristoe (student interns/field assistants); S.M. Karl and T.D. Hubbard (technical reviewers); P.E. Gallagher (cartographic and GIS advice); J.Y. Foley (donated gold sample); Alaska Placer Development, Inc., and Placer Dome Exploration (unpublished company data); and others.

\section{REFERENCES CITED}

Albanese, M.D., 1983, Bedrock geologic map of the Livengood B-4 Quadrangle, east-central Alaska: Alaska Division of Geological \& Geophysical Surveys Report of Investigation 83-3, 1 sheet, scale 1:40,000. http://doi. org/10.14509/2342

Allmendinger, R.W., Cardozo, N.C., and Fisher, D., 2012, Structural geology algorithms - Vectors and tensors in structural geology: Cambridge, England, Cambridge University Press, 302 p.

Athey, J.E., and Craw, P.A., 2004, Geologic maps of the Livengood SW C-3 and SE C-4 quadrangles, Tolovana mining district, Alaska: Alaska Division of Geological \& Geophysical Surveys Preliminary Interpretive Report 2004-3, 24 p. http://doi.org/10.14509/3308

Athey, J.E., Freeman, L.K., Harbo, L.A., and Lasley, P.S., 2014, Alaska's mineral industry 2013: Alaska Division of Geological \& Geophysical Surveys Special Report 69, 65 p. http://doi.org/10.14509/29128
Athey, J.E., Layer, P.W., and Drake, Jeff, 2004a, ${ }^{40} \mathrm{Ar} /{ }^{39} \mathrm{Ar}$ ages of rocks collected in the Livengood C-3, C-4, and B-5 quadrangles, Alaska: Alaska Division of Geological \& Geophysical Surveys Raw Data File 2004-1, 12 p. http://doi.org/10.14509/2972

Athey, J.E., Werdon, M.B., Newberry, R.J., Szumigala, D.J., Craw, P.A., and Hicks, S.A., 2004b, Geologic map of the Livengood SW C-3 and SE C-4 quadrangles, Tolovana mining district, Alaska: Alaska Division of Geological \& Geophysical Surveys Preliminary Interpretive Report 2004-3A, 1 sheet, scale 1:50,000. http://doi. org/10.14509/3309

Athey, J.E., Werdon, M.B., Szumigala, D.J., Newberry, R.J., Hicks, S.A., and Erickson, H.A., 2004c, Major-oxide, minor-oxide, and trace-element geochemical data from rocks collected in the Livengood Quadrangle, Alaska, in 2001 and 2003: Alaska Division of Geological \& Geophysical Surveys Raw Data File 2004-2, 13 p., 1 sheet, scale 1:63,360. http://doi.org/10.14509/2971

Barnes, D.F., 1961, Gravity low at Minto Flats, Alaska, in Short Papers in the Geologic and Hydrologic Sciences, Articles 293-435: U.S. Geological Survey Professional Paper 424-D, p. D 254-257.

Black, L.P., Kamo, S.L., Allen, C.M., Davis, D.W., Aleinikoff, J.N., Valley, J.W., Mundil, R., Campbell, I.H., Korsch, R.J., Williams, I.S., and Foudoulis, C., 2004, Improved ${ }^{206} \mathrm{~Pb} /{ }^{238} \mathrm{U}$ microprobe geochronology by the monitoring of a trace-element related matrix effect; SHRIMP, ID-TIMS, ELA-ICP-MS and oxygen isotope documentation for a series of zircon standards: Chemical Geology, v. 205, p. 115-140.

Blodgett, R.B., 1992, Taxonomy and paleobiogeographic affinities of an early Middle Devonian (Eifelian) gastropod faunule from the Livengood Quadrangle, eastcentral Alaska: Palaeontographica Abteilung A, v. 221, p. $125-168$.

Blodgett, R.B., Zhang, Ning, Ormiston, A.R., and Weber, F.R., 1988, A late Silurian age determination for the limestone of the "Lost Creek Unit," Livengood C-4 Quadrangle, east-central Alaska, in Hamilton, T.D., and Galloway, J.P., eds., Geological Studies in Alaska by the U.S. Geological Survey during 1987: U.S. Geological Survey Circular 1016, p. 54-56.

Bradley, D.C., McClelland, W.C., Wooden, J.L., Till, A.B., Roeske, S.M., Miller, M.L., Karl, S.M., and Abbott, J.G., 2007, Detrital zircon geochronology of some Neoproterozoic to Triassic rocks in interior Alaska, in Ridgway, K.D., Trop, J.M., Glen, J.M.G., and O’Neill, J.M., eds., Tectonic growth of a collisional continental margin; Crustal evolution of southern Alaska: Geological Society of America Special Paper 431, p. 155-189. http://doi. org/10.1130/2007.2431(07)

Brechtel, C.E., Carew, T.J., Myers, R., Pennstrom, W. Jr., Puchner, Chris, and Wilson, S., 2011, August 2011 summary report on the Livengood Project, Tolovana district, Alaska: Fairbanks, Alaska, International Tower Hill Mines, Ltd., NI 43-101 Technical Report, 275 p. 
Brosgé, W.P., Lanphere, M.A., Reiser, J.N., and Chapman, R.M., 1969, Probable Permian age of the Rampart Group, central Alaska: U.S. Geological Survey Bulletin 1294-B, $18 \mathrm{p}$.

Bundtzen, T.K., 1983, Bedrock geologic outcrop map of the Livengood B-3 Quadrangle, Alaska: Alaska Division of Geological \& Geophysical Surveys Report of Investigation 83-6, 1 sheet, scale 1:40,000. http://doi. org/10.14509/2345

Bundtzen, T.K., Eakins, G.R., and Conwell, C.N., 1982, Review of Alaska mineral resources 1981: Alaska Division of Geological \& Geophysical Surveys Annual Report 1981, 48 p., 2 sheets, scale 1:42,240. http://doi. org/10.14509/234

Burns, L.E., Geoterrex-Dighem, Stevens Exploration Management Corp., Emond, A.M., and Graham, G.R.C., 2015, Livengood mining district electromagnetic and magnetic airborne geophysical survey, data compilation: Alaska Division of Geological \& Geophysical Surveys Geophysical Report 2015-5. http://doi.org/10.14509/29412

Cady, J.W., and Morin, R.L., 1990, Aeromagnetic and gravity data, in Weber, F.R., McCammon, R.B., Rinehart, C.D., Light, T.D., and Wheeler, K.L., 1988, Geology and mineral resources of the White Mountains National Recreation Area, east-central Alaska: U.S. Geological Survey Open-File Report 88-284, 234 p., 31 sheets, scale 1:63,360.

Cathrall, J.B., Antweiler, J.C., and Mosier, E.L., 1987, Occurrence of platinum in gold samples from the Tolovana and Rampart mining districts, Livengood Quadrangle, Alaska: U.S. Geological Survey Open-File Report 87330, 12 p., 1 sheet.

Chang, Zhaoshan, Vervoort, J.D., McClelland, W.C., and Knaack, Charles, 2006, U-Pb dating of zircon by LAICP-MS: Geochemistry, Geophysics, Geosystems (G3), American Geophysical Union, v. 7, no. 5, 14 p. http:// doi.org/10.1029/2005GC001100

Chapman, R.M., Weber, F.R., Churkin, Michael, Jr., and Carter, Claire, 1980, The Livengood Dome Chert, a new Ordovician formation in central Alaska and its relevance to displacement on the Tintina fault: U.S. Geological Survey Professional Paper 1226-F, p. F1-F13.

Clough, J.G., and Goldhammer, R.K., 2000, Evolution of the Neoproterozoic Katakturuk Dolomite ramp complex, northeastern Brooks Range, Alaska, in Grotzinger, J.P., and James, N.P., eds., Carbonate Sedimentation and Diagenesis in the Evolving Precambrian World: SEPM Special Publication, v. 67, p. 209-241.

Foster, R.L., 1966, The petrology and structure of the Amy Dome area, Tolovana mining district, east-central Alaska: Rolla, University of Missouri, unpublished Ph.D. dissertation, $225 \mathrm{p}$.

Freeman, C.J., 2010, Geology and mineralization of the Shorty Creek Project, Livengood-Tolovana Mining District, Alaska: Technical report prepared for Select Resources Corporation, $61 \mathrm{p}$.
Freeman, C.J., and Schaefer, J.R.G., 1999, Alaska resource data file, Livengood Quadrangle: U.S. Geological Survey Open-File Report 99-574, 464 p. http://ardf.wr.usgs.gov/ Gehrels, G.E., 2009, Age Pick Program. University of Arizona Laserchron Center. https://sites.google.com/a/ laserchron.org/laserchron/

Gehrels, G.E., Valencia, V.A., and Ruiz, J., 2008, Enhanced precision, accuracy, efficiency, and spatial resolution of $\mathrm{U}-\mathrm{Pb}$ ages by laser ablation-multicollector-inductively coupled plasma-mass spectrometry: Geochemistry Geophysics Geosystems (G3), American Geophysical Union, v. 9, 13 p. http://doi.org/10.1029/2007GC001805

Gergen, L.D., Decker, J.E., and Plafker, George, 1988, A comparative petrologic study of sandstone from the Wilber Creek, Cascaden Ridge, and Wickersham units in the Livengood Quadrangle, in Galloway, J.P., and Hamilton, T.D., eds., Geological Studies in Alaska by the U.S. Geological Survey during 1987: U.S. Geological Survey Circular 1016, p. 57-60.

Glover, A.E., 1950, Placer gold fineness: Alaska Territorial Department of Mines Miscellaneous Report 195-1, 90 p. http://doi.org/10.14509/990

Griesel, G.A., Szumigala, D.J., Freeman, L.K., Newberry, R.J., Elliott, B.A., and Werdon, M.B., 2010, Major-oxide, minor-oxide, trace-element, and geochemical data from rocks collected in 2010 in the Tolovana mining district, Livengood B-3 and B-4 quadrangles, Alaska: Alaska Division of Geological \& Geophysical Surveys Raw Data File 2010-3, 31 p. http://doi.org/10.14509/21781

Hubbard, T.D., Braun, M.L., Westbrook, R.E., and Gallagher, P.E., 2011, High-resolution lidar data for infrastructure corridors, Livengood Quadrangle, Alaska, in Hubbard, T.D., Koehler, R.D., and Combellick, R.A., Highresolution lidar data for Alaska infrastructure corridors: Alaska Division of Geological \& Geophysical Surveys Raw Data File 2011-3K. http://doi.org/10.14509/23023

Karl, S.M., Ager, T.A., Hanneman, Karl, and Teller, S.D., 1988, Tertiary gold-bearing gravel at Livengood, Alaska, in Galloway, J.P., and Hamilton, T.D., eds. Geological Studies in Alaska by the U.S. Geological Survey during 1987: U.S. Geological Survey Circular 1016, p. 61-63.

Klipfel, Paul, Carew, Tim, and Pennstrom, William, Jr., 2009, October 2009 Summary Report on the Livengood Project, Tolovana District, Alaska: Canadian National Instrument 43-101 Technical Report Prepared for International Tower Hill Mines Ltd., 134 p.

Kuiper, K.F., Deino, A., Hilgen, P.J., Krijgsman, W., Renne, P.R., and Wijbrans, J.R., 2008, Synchronizing rock clocks of Earth history: Science, v. 320, no. 5875, p. 500-504. http://doi.org/10.1126/science.1154339

Lanphere, M.A., and Baadsraard, H., 2001, Precise K-Ar, ${ }^{40} \mathrm{Ar} /{ }^{39} \mathrm{Ar}, \mathrm{Rb}-\mathrm{Sr}$ and $\mathrm{U}-\mathrm{Pb}$ mineral ages from the 27.5 Ma Fish Canyon Tuff reference standard: Chemical Geology, v. 175, no. 3-4, p. 653-671. http://doi.org/10.1016/ S0009-2541(00)00291-6 
Layer, P.W., 2000, ${ }^{40} \mathrm{Ar} /{ }^{39} \mathrm{Ar}$ age of the El'gygytgyn impact event, Chukotka, Russia: Meteoritics and Planetary Science, v. 35, no. 3, p. 591-599.http://doi.org/10.1111/j.19455100.2000.tb01439.x

Layer, P.W., Hall, C.M., and York, Derek, 1987, The derivation of ${ }^{40} \mathrm{Ar}{ }^{39} \mathrm{Ar}$ age spectra of single grains of hornblende and biotite by laser step heating: Geophysical Research Letters, v. 14, no. 7, p. 757-760. http://doi.org/10.1029/ GL014i007p00757

Lister, G.S., and Snoke, A.W., 1984, S-C mylonites: Journal of Structural Geology, v. 6, no. 6, p. 617-638. http://doi. org/10.1016/0191-8141(84)90001-4

Ludwig, K.R., 1998, On the treatment of concordant uranium-lead ages: Geochimica et Cosmochimica Acta, v. 62 , no. 4, p. 665-676. http://doi.org/10.1016/S00167037(98)00059-3

McCoy, D.T., 2000, Mid-Cretaceous plutonic-related gold deposits of interior Alaska-Metallogenesis, characteristics, gold-associative mineralogy, and geochronology: Fairbanks, University of Alaska Fairbanks, Ph.D. dissertation, $177 \mathrm{p}$.

McDougall, Ian, and Harrison, T.M., 1999, Geochronology and thermochronology by the ${ }^{40} \mathrm{Ar} /{ }^{39} \mathrm{Ar}$ method, 2nd edition: New York, Oxford University Press, 269 p.

Mertie, J.B., Jr., 1917, The gold placers of the Tolovana district: U.S. Geological Survey Bulletin 662-D, p. 221-277.

Middlemost, E.A.K., 1985, Magmas and magmatic rocksAn introduction to igneous petrology: London, Longman Group, 266 p.

Minehane, D.L., and Rogers, J.A., 1997, 1997 Tolovana project report, Livengood, central-Interior Alaska: Placer Dome Exploration.

Moore, T.E., 1987, Geochemistry and tectonic setting of some rocks of the Franklinian Assemblage, central and eastern Brooks Range, in Tailleur, I.L., and Weimer, Paul, eds., Alaska North Slope Geology, a field trip guidebook: Society of Economic Paleontologists and Mineralogists and the Alaska Geological Society, v. 50, p. 691-710.

Nemchin, A.A., and Cawood, P.A., 2005, Discordance of the $\mathrm{U}-\mathrm{Pb}$ system in detrital zircons-Implication for provenance studies of sedimentary rocks: Sedimentary Geology, v. 182, no. 1-4, p. 143-162. http://doi.org/10.1016/j. sedgeo.2005.07.011

Newberry, R.J., and Haug, S.A., 1997, CIPW norm, traceelement, and $\mathrm{Sr}$ isotopic data for igneous rocks of the Tanana B-1 Quadrangle and vicinity: Alaska Division of Geological \& Geophysical Surveys Public Data File 97-29I, 16 p. http://doi.org/10.14509/1780

Nichols, O.G., 2013, Mineralization related to the biotite syenite at the Money Knob intrusion-related gold deposit, Livengood, Alaska: Golden, Colorado School of Mines, unpublished M.S. thesis, $116 \mathrm{p}$.

Paces, J.B., and Miller, J.D., 1993, Precise U-Pb ages of Duluth Complex and related mafic intrusions, northeastern Minnesota-Geochronological insights to physical, petrogenetic, paleomagnetic, and tectonomagmatic processes associated with the $1.1 \mathrm{Ga}$ Midcontinent Rift System: Journal of Geophysical Research, v. 98, no. B8, p. 13,997-14,013. http://doi.org/10.1029/93JB01159

Paton, Chad, Woodhead, J.D., Hellstrom, J.C., Hergt, J.M., Greig, Alan, and Maas, Roland, 2010, Improved laser ablation $\mathrm{U}-\mathrm{Pb}$ zircon geochronology through robust downhole fractionation correction: Geochemistry, Geophysics, Geosystems (G3), v. 11, no. 3, Q0AA06. http:// doi.org/10.1029/2009GC002618

Pearce, J.A., 1996, A user's guide to basalt discrimination diagrams, in Wyman, D.A., ed., Trace element geochemistry of volcanic rocks-Applications for massive sulfide exploration: Geological Association of Canada, Short Course Notes, v. 12, p. 79-113.

Péwé, T.L., 1975, Quaternary geology of Alaska: U.S. Geological Survey Professional Paper 835, $145 \mathrm{p}$.

Péwé, T.L., Wahrhaftig, Clyde, and Weber, F.R., 1966, Geologic map of the Fairbanks Quadrangle, Alaska: U.S. Geological Survey Miscellaneous Geological Investigations Map I-455, 5 p., 1 sheet, scale 1:250,000.

Reger, R.D., 1987, Preliminary photointerpretive maps of the geology, geologic materials, permafrost, and wetlands classification of the Fairbanks C-5 Quadrangle, Alaska: Alaska Division of Geological \& Geophysical Surveys Public Data File 87-19, 22 p., 4 sheets, scale 1:31,680. http://doi.org/10.14509/1321

Reger, R.D., and Burns, P.A.C., 2013, Surficial-geologic map of the Livengood area, central Alaska: Alaska Division of Geological \& Geophysical Surveys Report of Investigation 2013-2, 1 sheet, scale 1:50,000. http://doi. org/10.14509/25179

Reifenstuhl, R.R., Dover, J.H., Newberry, R.J., Clautice, K.H., Liss, S.A., Blodgett, R.B., and Weber, F.R., 1998, Interpretive geologic bedrock map of the Tanana A-1 and A-2 quadrangles, central Alaska: Alaska Division of Geological \& Geophysical Surveys Public Data File 98-37B v. 1.1, 17 p., 1 sheet, scale 1:63,360. http://doi. org/10.14509/1864

Renne, P.R., Deino, A.L., Walter, R.C., Turrin, B.D., Swisher, C.C. III, Becker, T.A., Curtis, G.H., Sharp, W.D., and Jaouni, A.-R., 1994, Intercalibration of astronomical and radioisotopic time: Geology, v. 22, no. 9, p. 783-786. http://doi.org/10.1130/0091-7613(1994)022<0783:IOA ART > 2.3.CO;2

Renne, P.R., Swisher, C.C., Deino, A.L., Karner, D.B., Owens, T.L., and DePaolo, D.J., 1998, Intercalibration of standards, absolute ages and uncertainties in ${ }^{40} \mathrm{Ar} /{ }^{39} \mathrm{Ar}$ dating: Chemical Geology, v. 45, no. 1-2, p. 117-152. http://doi.org/10.1016/S0009-2541(97)00159-9

Rigby, J.K., Blodgett, R.B., and Britt, B.B., 2008, Ordovician sponges from west-central and east-central Alaska and western Yukon Territory, Canada: Bulletin of Geosciences, v. 83, no. 2, p. 153-168.

Rinehart, C.D., Light, T.D., and Shew, N.B., 1997, Petrography and radiometric ages for selected rocks from the Livengood Quadrangle, Alaska: U.S. Geological Survey Open-File Report 97-484-D, 22 p. 
Robinson, M.S., 1983, Bedrock geologic map of the Livengood C-4 Quadrangle, east-central Alaska: Alaska Division of Geological \& Geophysical Surveys Report of Investigation 83-4, 1 sheet, scale 1:40,000. http://doi. org/10.14509/2343

Robinson, M.S., and Metz, P.A., 1979, Evaluation of the mineral resources of the pipeline corridor, phases I and II: University of Alaska Mineral Industry Research Laboratory Open File 79-2, 272 p. http://dggs.alaska. gov/pubs/id/14981

Samson, S.D., and Alexander, E.C., Jr., 1987, Calibration of the interlaboratory ${ }^{40} \mathrm{Ar} /{ }^{39} \mathrm{Ar}$ dating standard, MMhb1: Chemical Geology, Isotope Geoscience Section, v. 66, no. 1-2, p. 27-34.

Samuel Engineering, 2013, Livengood gold project feasibility study, Livengood, Alaska: Canadian National Instrument 43-101 Technical Report Prepared for International Tower Hill Mines Ltd., 189 p.

Saunders, R.H., 1955, Report on the Griffin Nickel prospect, Livengood Quadrangle: Alaska Territorial Department of Mines Prospect Evaluation 49-13, 8 p.

Silberling, N.J., Jones, D.L., Monger, J.W.H., Coney, P.J., Berg, H.C., and Plafker, George, 1994, Lithotectonic terrane map of Alaska and adjacent parts of Canada, in Plafker, George, and Berg, H.C., eds., The Geology of Alaska: Geological Society of America, 1 sheet, scale $1: 2,500,000$.

Skudrzyk, F.J., Bandopadhyay, Sukumar, and Rybachek, Rose, 1987, Experimental underground placer mining on Wilbur Creek, in Albanese, M.D., and Campbell, B.W., compilers, Placer mining-jobs for Alaska: Proceedings of the Ninth Annual Alaska Conference on Placer Mining-1987: Alaska Division of Geological \& Geophysical Surveys Miscellaneous Publication 9I, p. 89-119. http://doi.org/10.14509/680

Smith, P.S., 1941, Mineral industry of Alaska-1940: U.S. Geological Survey Bulletin 926, 37 p.

Smith, T.E., 1983, Bedrock geologic map of the Livengood C-3 Quadrangle, east-central Alaska: Alaska Division of Geological \& Geophysical Surveys Report of Investigation 83-5, 1 sheet, scale 1:40,000. http://doi.org/10.14509/2344

Stacey, J.S., and Kramer, J.D., 1975, Approximation of terrestrial lead isotope evolution by a two stage model: Earth and Planetary Science Letters, v. 26, no. 2, p. 207-221. http://doi.org/10.1016/0012-821X(75)90088-6

Steiger, R.H., and Jaeger, E., compilers, 1977, Subcommission on geochronology - Convention on the use of decay constants in geo- and cosmochronology: Earth and Planetary Science Letters, v. 36, no. 3, p. 359-362. http://doi.org/10.1016/0012-821X(77)90060-7

Szumigala, D.J., Griesel, G.A., Newberry, R.J., Freeman, L.K, Elliott, B.A., and Werdon, M.B., 2010, Mineral resource studies in the Tolovana mining district-Is the Money Knob gold deposit a rogue elephant or is the rest of the herd nearby?: Poster presentation to the Yukon Geoscience Forum.
Thompson, J.F.H., and Newberry, R.J., 2000, Gold deposits related to reduced granitic intrusions, in Hagemann, S.G., and Brown, P.E., eds., Gold in 2000: Society of Economic Geologists Reviews in Economic Geology, v. 13, p. $377-400$.

Vermeesch, Pieter, 2012, On the visualisation of detrital age distributions: Chemical Geology, v. 312-313, p. 190-194. http://doi.org/10.1016/j.chemgeo.2012.04.021

Waythomas, C.F., TenBrink, N.W., and Ritter, D.F., 1984, Surficial geology of the Livengood B-3, B-4, C-3, and C-4 quadrangles, Yukon-Tanana Upland, Alaska: Alaska Division of Geological \& Geophysical Surveys Report of Investigation 84-6, 1 sheet, scale 1:63,360. http://doi. org/10.14509/2365

Weber, F.R., Blodgett, R.B., Harris, A.G., and Dutro, J.T., Jr., 1994, Paleontology of the Livengood Quadrangle, Alaska: U.S. Geological Survey Open-File Report 94215, 24 p., 1 sheet, scale 1:250,000.

Weber, F.R., Smith, T.E., Hall, M.H., and Forbes, R.B., 1985, Geologic guide to the Fairbanks-Livengood area, eastcentral Alaska: AAPG-SEPM-SEG Meeting, Anchorage, Alaska, 1985, Alaska Geological Society, 44 p.

Weber, F.R., Wheeler, K.L., Dover, J.H., Rinehart, C.D., Blodgett, R.B., Cady, J.W., Karl, S.M., McCammon, R.B., and Miyaoka, R., 1988, Geologic framework, in Weber, F.R., McCammon, R.B., Rinehart, C.D., Light, T.D., and Wheeler, K.L., eds., Geology and mineral resources of the White Mountains National Recreation Area, eastcentral Alaska: U.S. Geological Survey Open-File Report 88-284, p. 4-58.

Weber, F.R., Wheeler, K.L., Rinehart, C.D., Chapman, R.M., and Blodgett, R.B., 1992, Geologic map of the Livengood Quadrangle, Alaska: U.S. Geological Survey Open-File Report 92-562, 20 p., 1 sheet, scale 1:250,000.

Wheeler, K.L., and Weber, F.R., 1988, Bibliography of selected references on the geology of the Livengood Quadrangle, east-central Alaska: U.S. Geological Survey Open-File Report 88-203, 79 p.

Wilson, F.H., Dover, J.H., Bradley, D.C., Weber, F.R., Bundtzen, T.K., and Haeussler, P.J., 1998, Geologic map of central (Interior) Alaska: U.S. Geological Survey OpenFile Report 98-133, 76 p., 3 sheets, scale 1:500,000.

Winchester, J.A., and Floyd, P.A., 1977, Geochemical discrimination of different magma series and their differentiation products using immobile elements: Chemical Geology, v. 20, p. 325-343. http://doi.org/10.1016/00092541(77)90057-2

York, Derek, Hall, C.M., Yanase, Yotaro, Hanes, J.A., and Kenyon, W.J., $1981,{ }^{40} \mathrm{Ar} /{ }^{39} \mathrm{Ar}$ dating of terrestrial minerals with a continuous laser: Geophysical Research Letters, v. 8, no. 11, p. 1,136-1,138.

Zhang, M., Ewing, R.C., Boatner, L.A., Salje, E.K.H., Weber, W.J., Daniel, P., Zhang, Y., and Farnan, I., 2009, $\mathrm{Pb}^{*}$ irradiation of synthetic zircon $\left(\mathrm{ZrSiO}^{4}\right)$ - Infrared spectroscopic study-Reply: American Mineralogist, v. 94, p. 856-858. http://doi.org/10.2138/am.2009.542 
INTENTIONALLY LEFT BLANK 


\section{APPENDIX A}

\section{${ }^{40} \mathrm{Ar} /{ }^{39} \mathrm{Ar}$ ANALYSIS OF SAMPLE 2010MBW016B-BIOTITE}

\section{Methods}

One rock sample was submitted for ${ }^{40} \mathrm{Ar} /{ }^{39} \mathrm{Ar}$ analysis to the Geochronology laboratory at UAF, where it was crushed, sieved, washed, and hand-picked for biotite mineral phases. The monitor mineral MMhb-1 (Samson and Alexander, 1987) with an age of 523.5 Ma (Renne and others, 1994) was used to monitor neutron flux (and calculate the irradiation parameter, J). The sample and standards were wrapped in aluminum foil and loaded into aluminum cans of $2.5 \mathrm{~cm}$ diameter and $6 \mathrm{~cm}$ height. The samples were irradiated in position $5 \mathrm{c}$ of the uranium-enriched research reactor of McMaster University in Hamilton, Ontario, Canada, for 20 megawatt-hours.

Upon their return from the reactor, the sample and monitors were loaded into 2-mm-diameter holes in a copper tray that was then loaded in an ultra-high vacuum extraction line. The monitors were fused, and samples heated, using a 6-watt argon-ion laser following the technique described in York and others (1981), Layer and others (1987) and Layer (2000). Argon purification was achieved using a liquid nitrogen cold trap and an SAES Zr-Al getter at $400^{\circ} \mathrm{C}$. The sample was analyzed in a VG-3600 mass spectrometer at the Geophysical Institute, University of Alaska Fairbanks. The argon isotopes measured were corrected for system blank and mass discrimination, as well as calcium, potassium, and chlorine interference reactions following procedures outlined in McDougall and Harrison (1999). System blanks generally were $2 \times 10^{-16}$ mol ${ }^{40} \mathrm{Ar}$ and $2 \times 10^{-18} \mathrm{~mol}{ }^{36} \mathrm{Ar}$, which are 10 to 50 times smaller than fraction volumes. Mass discrimination was monitored by running both calibrated air shots and a zero-age glass sample. These measurements were made on a weekly to monthly basis to check for changes in mass discrimination.

A summary of the ${ }^{40} \mathrm{Ar} /{ }^{39} \mathrm{Ar}$ results is given in table A-1, with all ages quoted to the \pm 1 sigma level and calculated using the constants of Steiger and Jaeger (1977). The integrated age is the age derived from the total gas measured and is equivalent to a potassium-argon (K-Ar) age. The spectrum provides a plateau age if three or more consecutive gas fractions represent at least 50 percent of the total gas release and are within two standard deviations of each other (Mean Square Weighted Deviation less than 2.5).

\section{Discussion}

A biotite separate from sample 2010MBW016B (map location A5) was analyzed; The sample was described in thin section as a fine-grained, equigranular quartz diorite containing 60 percent plagioclase, 30 percent biotite, 10 percent quartz (modal visual estimates). Sampled from float in soil. The integrated age (67.8 $\pm 0.5 \mathrm{Ma})$, plateau age $(68.0 \pm 0.5 \mathrm{Ma})$, and isochron age $(67.9 \pm 0.5 \mathrm{Ma})$ are within error. We prefer the plateau age of $\mathbf{6 8 . 0} \pm \mathbf{0 . 5}$ Ma because of evidence of slight alteration during the first two low-temperature steps and because of the large error on the regression to initial ${ }^{40} \mathrm{Ar} /{ }^{36} \mathrm{Ar}$ due to the generally homogenous radiogenic nature of the steps used in the plateau age determination.

Table A-1. Results of ${ }^{40} \mathrm{Ar} /{ }^{39} \mathrm{Ar}$ dating of biotite from sample $2010 \mathrm{MBW} 016 \mathrm{~B}\left(65.44400^{\circ} \mathrm{N}, 148.56559^{\circ} \mathrm{W}, \mathrm{WGS} 84\right)^{a, b}$

\begin{tabular}{|c|c|c|c|c|c|c|}
\hline Sample & Min. & $\begin{array}{c}\text { Integrated } \\
\text { Age (Ma) }\end{array}$ & $\begin{array}{c}\text { Plateau } \\
\text { Age (Ma) }\end{array}$ & $\begin{array}{c}\text { Plateau } \\
\text { Information }\end{array}$ & $\begin{array}{c}\text { Isochron } \\
\text { Age (Ma) }\end{array}$ & $\begin{array}{c}\text { Isochron or other } \\
\text { information }\end{array}$ \\
\hline $\begin{array}{c}\text { 2010MBW016B } \\
\text { (lab sample no. } \\
\text { 10MBW16B) }\end{array}$ & $\mathrm{BI}$ & $67.8 \pm 0.5$ & $\mathbf{6 8 . 0 \pm 0 . 5}$ & $\begin{array}{c}8 \text { of } 10 \text { fractions } \\
98.3 \%{ }^{39} \mathrm{Ar} \text { release } \\
\mathrm{MSWD}=0.31\end{array}$ & $67.9 \pm 0.5$ & $\begin{array}{c}40 \mathrm{Ar} /{ }^{36} \mathrm{Ar} \mathrm{r}_{\mathrm{i}}=289.9 \pm 31.2 \\
\mathrm{MSWD}=0.34\end{array}$ \\
\hline
\end{tabular}

aSamples analyzed with standard MMhb-1 with an age of 523.5 Ma.

${ }^{\mathrm{b}}$ Most robust age in bold. 


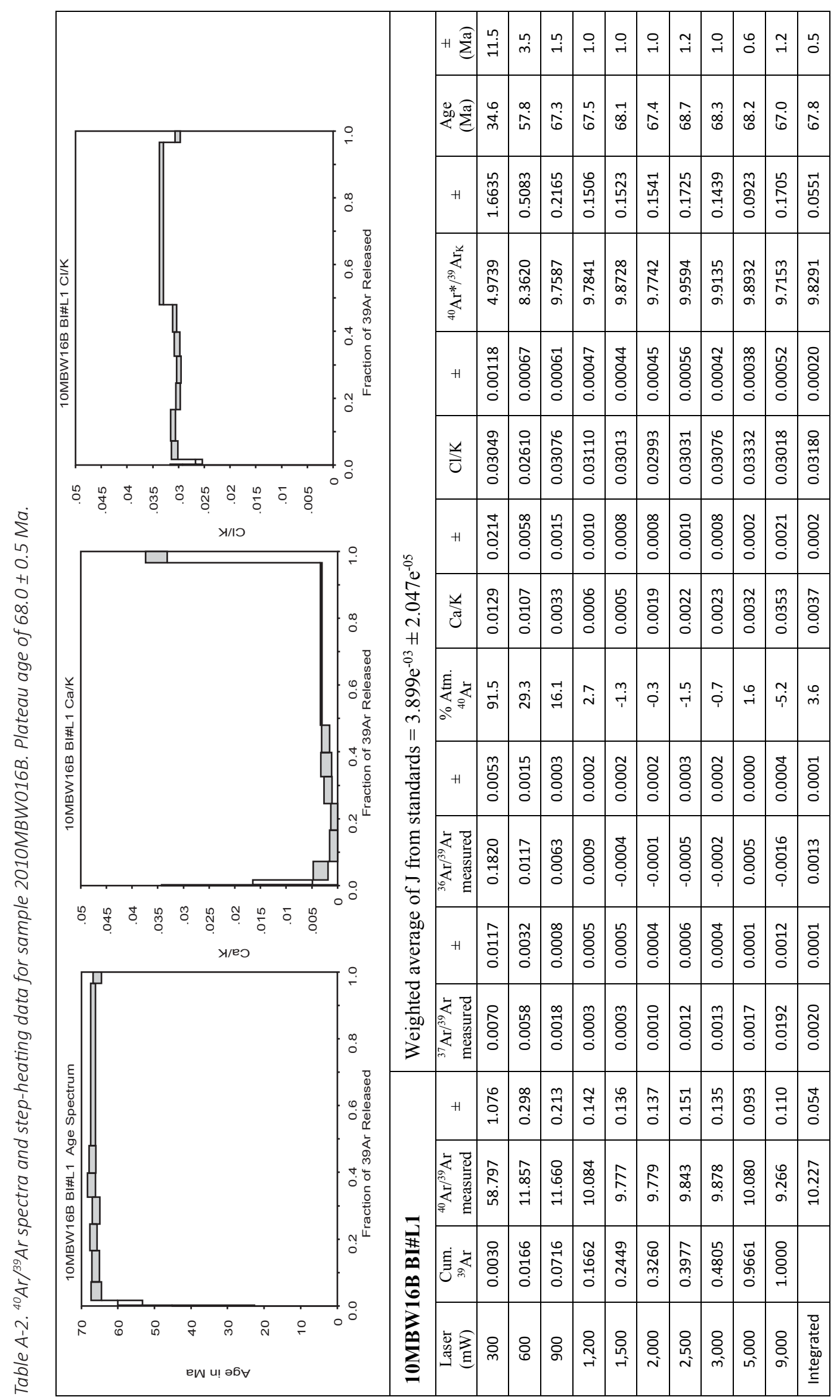




\section{APPENDIX B}

\section{DIRECT X-RAY FLUORESCENCE (XRF) METHODOLOGY}

Polished sample slabs were directly analyzed using the PANalytical Axios wavelength-dispersive XRF and SuperQ ${ }^{\mathrm{TM}}$ software at the University of Alaska Fairbanks. $\mathrm{Nb}, \mathrm{Rb}, \mathrm{Sr}, \mathrm{Y}$, and $\mathrm{Zr}$ were measured using the $37 \mathrm{mmRbSrYZr}$ analytical routine; other elements were measured with the IQ+37mmVac analytical routine. The $37 \mathrm{mmRbSrYZr}$ routine uses specific predetermined peak and background positions for which X-ray intensities are measured for 2-800 seconds (depending on the element). The intensity of the Rh Compton peak is used to estimate mass-absorption coefficients (MACs) for both unknowns and well-characterized natural standards. Peak intensities are computed and converted to concentrations using calibration curves employing at least ten natural rock standards.

These procedures are routinely checked by analysis of secondary natural standards that were not employed in making the calibration curves. Elemental abundances are typically within 2-5 percent of the amount present for concentrations $>10$ times the detection limit; within 5-10 percent of the amount present for concentrations 4-10 times the detection limit, and within 30 percent of the amount present for concentrations near the detection limit. The IQ37mmVac program scans over a series of energies corresponding to a range from Ce K-alpha to O K-alpha. Peak heights and backgrounds, and X-ray elemental interferences are picked with the software and checked manually to ensure quality control. Elemental abundances for all elements with atomic numbers between 8 and 92 are estimated from artificial standards; these estimations are used to calculate MACs for each element present above the detection limit. Revised concentrations are employed to calculate revised MACs until a stable solution is determined. Elemental abundances are then normalized to 100 percent. The software is routinely checked using pressed pellets of well-characterized natural rock standards. Elemental abundances are within 1-2 percent of the amount present for major elements, 2-5 percent of the amount present for minor elements, and 5-10 percent of the amount present for trace elements. 
Table B-1. Direct X-ray fluorescence (XRF) data collected on felsic igneous rocks in the study area.

\begin{tabular}{|c|c|c|c|c|c|c|}
\hline SampleID & Group & $\mathrm{TiO}_{2}$ & $\mathbf{Y}$ & $\mathrm{Zr}$ & Nb & Th \\
\hline 2010LF123A & Dcv & 0.30 & 124 & 1780 & 114 & \\
\hline 2010LF121A & Dcv & 0.27 & 104 & 1245 & 92 & \\
\hline 2010Z139A & Kcrp & 0.89 & 70 & 508 & 46 & 12 \\
\hline 2010RN186A & Kcrp & 0.61 & 50 & 449 & 40 & 23 \\
\hline 2010RN195A & Kcrp & 0.75 & 76 & 502 & 72 & 30 \\
\hline 2010GG079A & Kcrp & 0.70 & 74 & 564 & 53 & 17 \\
\hline 2010RN169A & Kcrp & 0.68 & 56 & 484 & 44 & 28 \\
\hline 2010RN176A & Kcrp & 0.66 & 55 & 525 & 49 & 18 \\
\hline 2010RN173A & Kcrp & 0.67 & 51 & 433 & 44 & 25 \\
\hline 2010LF125A & Kcrp & 0.71 & 87 & 543 & 46 & 13 \\
\hline 2010RN172A & Kcrp & 0.75 & 64 & 491 & 46 & 17 \\
\hline 2010LF114A & Kcrp & 0.70 & 82 & 619 & 51 & \\
\hline RK22805 & $\mathrm{Kmk}$ & 0.37 & 26 & 190 & 24 & \\
\hline RK22806 & Kmk & 0.55 & 27 & 369 & 21 & \\
\hline RK611082 & Kmk & 0.53 & 30 & 241 & 19 & \\
\hline RK800165 & $\mathrm{Kmk}$ & 0.55 & 23 & 179 & 34 & \\
\hline RK800166 & $\mathrm{Kmk}$ & 0.42 & 19 & 131 & 28 & \\
\hline RK800174 & $\mathrm{Kmk}$ & 0.56 & 32 & 246 & 40 & \\
\hline RK800185 & Kmk & 0.48 & 26 & 320 & 21 & \\
\hline RK800186 & $\mathrm{Kmk}$ & 0.58 & 35 & 171 & 35 & \\
\hline RK800187 & Kmk & 0.49 & 33 & 164 & 33 & \\
\hline RK800190 & Kmk & 0.43 & 25 & 220 & 18 & \\
\hline RK803075 & $\mathrm{Kmk}$ & 0.45 & 24 & 336 & 26 & \\
\hline RK803568 & Kmk & 0.48 & 27 & 450 & 22 & \\
\hline RK803571 & $\mathrm{Kmk}$ & 0.46 & 36 & 344 & 24 & \\
\hline RK803575 & Kmk & 0.55 & 37 & 361 & 46 & \\
\hline RK808547 & Kmk & 0.32 & 23 & 184 & 31 & \\
\hline RK808550 & $\mathrm{Kmk}$ & 0.37 & 32 & 311 & 43 & \\
\hline RK808551 & Kmk & 0.57 & 30 & 333 & 47 & \\
\hline RK336628 & Kmk & 0.33 & 44 & 425 & 31 & \\
\hline 2010MBW016B & Ksc & 0.91 & 14 & 142 & 18 & \\
\hline 2010LF056A & Ksc & 0.37 & 7 & 130 & 7 & 11 \\
\hline 2010LF006A & Ksc & 0.39 & 8 & 129 & 7 & 12 \\
\hline 2010RN122A & Ksc & 0.45 & 8 & 121 & 8 & 23 \\
\hline 2010GG003A & Ksc & 0.49 & 9 & 120 & 7 & 13 \\
\hline 2010MBW013A & Ksc & 0.63 & 7 & 113 & 14 & \\
\hline 2010RN126A & Ksc & 0.44 & 10 & 128 & 8 & 35 \\
\hline 2010MBW016A & Ksc & 0.46 & 10 & 121 & 11 & \\
\hline 2010GG049C & Ksc & 0.45 & 9 & 130 & 8 & 14 \\
\hline 2010MBW015A & Ksc & 0.42 & 4 & 100 & 12 & \\
\hline 2010LF233B & Ksc & 0.79 & 11 & 137 & 13 & 15 \\
\hline 2010BAE003A & Ksc & 0.63 & 13 & 123 & 14 & \\
\hline 2010Z203A & Ksc & 0.59 & 9 & 137 & 17 & 17 \\
\hline 2010RN073A & Ksc & 0.58 & 10 & 131 & 11 & 12 \\
\hline 2010GG014B & Ksc & 0.55 & 13 & 128 & 12 & 18 \\
\hline 2010BAE008B & Ksc & 0.55 & 10 & 124 & 14 & \\
\hline
\end{tabular}




\section{APPENDIX C}

\section{DETRITAL ZIRCON ANALYSIS OF SAMPLE 10Z222A}

\section{U-Pb Zircon LA-ICP-MS, Apatite to Zircon, Inc.}

LA-ICP-MS Session Details — Data were collected for the following isotopic masses: ${ }^{202} \mathrm{Hg},{ }^{204} \mathrm{Hg}+{ }^{204} \mathrm{~Pb},{ }^{206} \mathrm{~Pb},{ }^{207} \mathrm{~Pb},{ }^{208} \mathrm{~Pb}$, ${ }^{232} \mathrm{Th},{ }^{235} \mathrm{U}$, and ${ }^{238} \mathrm{U}$ ( 250 data scans over $30 \mathrm{~s}$ ) followed by ${ }^{28} \mathrm{Si}$ and ${ }^{91} \mathrm{Zr}$ ( 5 data scans over $4 \mathrm{~s}$ ). The instruments used were a New Wave YAG $213 \mathrm{~nm}$ laser ablation (LA) system in line with a Finnigan Element2 magnetic sector, inductively coupled plasma, mass spectrometer (ICP-MS) at the Washington State University Geoanalytical Laboratory in Pullman, Washington, U.S.A. (Chang and others, 2006). All analyses were performed using a $20 \mu \mathrm{m}$ spot. Following approximately $6 \mathrm{~s}$ of background data collection, laser ablation commenced and data were collected for the ablated material. Ablated material was transported to the plasma line using He; Ar was the plasma gas.

Zircon standards for which independently accepted ages are published were designated as primary, secondary, and tertiary for purposes of $\mathrm{U}-\mathrm{Pb}$ age calibration (see table 1 below). Two primary and two secondary standard spots were analyzed prior to and following each group of $\sim 25-30$ tertiary standards and/or unknown sample spots. Five spots of each tertiary standard were analyzed near the beginning and again near the end of the session.

Data Modeling-Previous LA-ICP-MS studies of U-Pb zircon dating deployed the so-called intercept method which assumes that isotopic ratio varies linearly with scan number due solely to linearly varying isotopic fractionation (Chang and others, 2006; Gehrels and others, 2008). For the intercept method, a line is fitted to background-corrected isotopic ratio (for example, ${ }^{206} \mathrm{~Pb} /{ }^{238} \mathrm{U}$ ) versus data scan number and the intercept of the fitted line (corresponding to data scan number $=0)$ is used as the isotopic ratio for age calculation and the error on the intercept is used for age error calculation. For this study, individual isotopes were modeled by fitting a sum of 10 Gaussian equations to the raw signal data (not background corrected) using chi-squared minimization. Two fitting passes were performed: after the first pass, all raw signal values greater than two standard deviations away from the sum of fitted Gaussians were designated outliers; the second pass fit the sum of Gaussians to the data excluding the outliers. The advantage of the present approach is that it avoids the assumption of linearly varying isotopic ratio with scan number, an assumption easily violated for zircons that may contain useful information (for example, a zircon for which the ablation pit variably penetrates two zones having different $\mathrm{U}-\mathrm{Pb}$ ages).

Measured background values for each isotope at each LA-ICP-MS spot were calculated as follows: (a) the final background scan was assigned as the scan closest to the global minima ${ }^{232} \mathrm{Th}$ and ${ }^{238} \mathrm{U}$ values; if no such global minima were found, the analysis was deemed a failure, (b) a line was fitted to the background values, outliers identified, and a line again fitted to the data excluding the outliers, (c) for a fitted line exhibiting a negative slope (indicative of a decaying background), the value of the line at the last background scan was assigned as the background value; for a fitted line exhibiting a zero or positive slope, the mean value of the data excluding the outliers was assigned as the background value, and (d) the error of the background value was set equal to the standard deviation of the all background values (excluding outliers) about their fitted line (negative slope) or mean (zero or positive slope).

Session-wide fitted background values for each isotope were determined using all zircon standards and applied to all spots in the session. These steps were taken for each isotope: (a) measured background value versus spot number in the session was fitted to a 3rd-order polynomial, outliers identified, and the fitting repeated excluding the outliers, and (b) fitted background at each session spot was calculated using the 3rd-order polynomial. Session-wide fitted background error was set equal to the standard deviation of the measured background values (excluding outliers) about their respective fitted 3rdorder polynomial. For any spot (standard or unknown) where the measured background value exceeded the session-wide fitted value by more than $2 \sigma$, the background error was set equal to $1 \sigma$ plus one-half of the amount by which the measured background value exceeded the session-wide fitted value by $2 \sigma$.

The sum of fitted Gaussians was used here primarily to identify outlier data and characterize signal noise. After the second fitting pass, the standard deviation of the non-outlier data about their respective sum of fitted Gaussians was taken as the absolute signal error for each data scan. When $\mathrm{N}$ data scans contribute to a single isotopic signal value used for age calculation (only concordant scans when the number of concordant data scans is greater than zero; all data scans for common $\mathrm{Pb}$-correction based on isotopic sums), the error of the single isotopic signal value was set equal to the product of (a) N1/2 and (b) the absolute signal error for each data scan.

$\boldsymbol{P b} / \boldsymbol{U}$ Fractionation Factor-Fractionation factors were determined for each data scan of each primary standard spot. For a particular isotopic ratio (for example, ${ }^{206} \mathrm{~Pb} /{ }^{238} \mathrm{U}$ ), the fractionation factor as used here equals the accepted isotopic ratio divided by the measured ratio. A two dimensional grid (spot number, scan number) of fractionation factors for each isotopic ratio was constructed for the session as a whole by fitting a series of 4th-order polynomials (excluding outliers). Under the 
operating conditions of the LA-ICP-MS sessions in this study, fractionation factors were found to vary strongly with scan number, decreasing with increasing scan number (presumably due to increasing ablation pit depth and the effect this had on fractionation; for example, Paton and others, 2010).

Fractionation factors were calculated using isotopic values based on the sum of fitted Gaussians. Ages, including when the standards were treated as unknowns, were calculated using raw isotopic signal values (excluding outliers) to avoid any bias due to artifacts of the fitting of the sum of Gaussians.

Fractionation Factor Adjustment for Integrated $\alpha$-damage-Zircon is widely known to accumulate $\alpha$-radiation damage (for example, Zhang and others, 2009 and references therein). It is assumed here that increased $\alpha$-damage in a zircon leads to a decrease in the hardness of the zircon; this in turn leads to a faster rate of laser penetration into the zircon during ablation leading to shift in isotopic fractionation. Ages calculated for the primary, secondary, and tertiary zircon standards, when those standards were treated as unknowns, were used to construct a fractionation factor correction curve (exponential form). Much previous work has attempted to understand the chemical basis for why some standards work better with some zircons. The notion of matrix-matched standard and unknown zircons has been proposed largely on the basis of trace element chemistry (for example, Black and others, 2004). Here, time and crystallographic damage, parameters invisible to instruments used to characterize trace element chemistry, were introduced and applied in conjunction with $U$ and Th chemistry.

Common Pb Correction-Common Pb was subtracted out using the Stacey and Kramer (1975) common Pb model for Earth. Ages and common $\mathrm{Pb}$ ratio were determined iteratively using a pre-set, session-wide minimum common $\mathrm{Pb}$ age value (default for each session was the age of the oldest age standard which for both Ap and Zrn was 1099 Ma FC-1 and/or FC-5z).

Preferred Age and Concordia Age - Uranium decay constants and the ${ }^{238} \mathrm{U} / 235 \mathrm{U}$ isotopic ratio reported in Steiger and Jaeger (1977) were used in this study. ${ }^{207} \mathrm{~Pb} /{ }^{235} \mathrm{Uc}\left({ }^{235} \mathrm{Uc}=137.88^{238} \mathrm{U}\right),{ }^{206} \mathrm{~Pb} /{ }^{238} \mathrm{U}$, and ${ }^{207} \mathrm{~Pb} /{ }^{206} \mathrm{~Pb}$ ages were calculated for each data scan and checked for concordance; concordance here was defined as overlap of all three ages at the $1 \sigma$ level (the use of $2 \sigma$ level was found to skew the results to include scans with significant common $\mathrm{Pb}$ ). The background-corrected isotopic sums of each isotope were calculated for all concordant scans. The precision of each isotopic ratio was calculated by using the background and signal errors for both isotopes. The fractionation factor for each data scan, corrected for the effect of accumulated $\alpha$-damage, was weighted according to the ${ }^{238} \mathrm{U}$ or ${ }^{232} \mathrm{Th}$ signal value for that data scan; an overall weighted mean fractionation factor for all concordant data scans was used for final age calculation.

If the number of concordant data scans for a spot was greater than zero, then either the ${ }^{206} \mathrm{~Pb} /{ }^{238} \mathrm{U}$ or ${ }^{207} \mathrm{~Pb} /{ }^{206} \mathrm{~Pb}$ age was chosen as the "preferred age", whichever exhibited the lower relative error. If zero concordant data scans were observed, then the common $\mathrm{Pb}$-corrected age based on isotopic sums of all acceptable scans was chosen as the "preferred age". Common $\mathrm{Pb}$ was subtracted out using the Stacey and Kramer (1975) common $\mathrm{Pb}$ model for Earth. Ages and common Pb ratio were determined iteratively using a pre-set, session-wide minimum common $\mathrm{Pb}$ age value (default for each session was the age of the oldest age standard which for both Ap and Zrn was 1099 Ma FC-1 and/or FC-5z).

Concordia ages (including decay constant errors) were also calculated for each analysis, and this value was used as the accepted age of each detrital zircon grain instead of the "preferred age" as defined above (Ludwig, 1998; Nemchin and Cawood, 2005). The concordia age makes optimum use of both decay schemes and obviates the need to choose an arbitrary age threshold for selecting either the ${ }^{206} \mathrm{~Pb} /{ }^{238} \mathrm{U}$ or ${ }^{207} \mathrm{~Pb} /{ }^{206} \mathrm{~Pb}$ age as the "preferred age" for an individual grain (Ludwig, 1998). Additionally, the concordia age calculation gives probability of concordance (POC) for each analysis, which provides a useful means of assessing concordance for all grains regardless of age. After calculating the concordia age and associated statistics for each analysis, data were screened for uncertainty and probability of concordance. Analyses with greater than $10 \%$ age uncertainty (at $1 \sigma$ ) were excluded or "filtered" from plots and statistical treatments. Grains with a POC $<0.1$ were also excluded unless the grain was older than $1000 \mathrm{Ma}$ and had a calculated concordance (comparison of ${ }^{206} \mathrm{~Pb} /{ }^{238} \mathrm{U}$ or ${ }^{207} \mathrm{~Pb} /{ }^{206} \mathrm{~Pb}$ ages) between $80 \%$ and $105 \%$. Data that were excluded are reported in the data table but are highlighted by strike-through to indicate that they were not considered further. Age probability diagrams were generated using the Kernel Density Estimation (KDE) method of Vermeesch (2012), and the age of the youngest statistically significant age population (three or more grains with ages that overlap within error and define a distinct population) is labeled together with other prominent age populations. Age populations were calculated using the AgePick macro for Microsoft Excel (Gehrels, 2009). All KDE diagrams were generated using a bandwidth of 15 (that is, kernel density estimation; Vermeesch, 2012) to ensure consistency throughout. Histogram bins, where shown, generally represent approximately $20 \mathrm{~m} . \mathrm{y}$.

\section{Results}

A sample of conglomerate from the Amy Creek siliceous mudstone and chert unit (IRZZmc) was analyzed with results depicted in tables $\mathrm{C} 1, \mathrm{C} 3$, and figures $\mathrm{C} 1-\mathrm{C} 3$. The field description of this sample indicates that it is nearly clast supported, poorly sorted, angular to subrounded conglomerate, and has clasts 1-10 mm. Recognizable clast lithologies include abundant chert. Radiolarians are visible in some of the chert clasts in thin section (J. Dumoulin, written commun. 2016). 


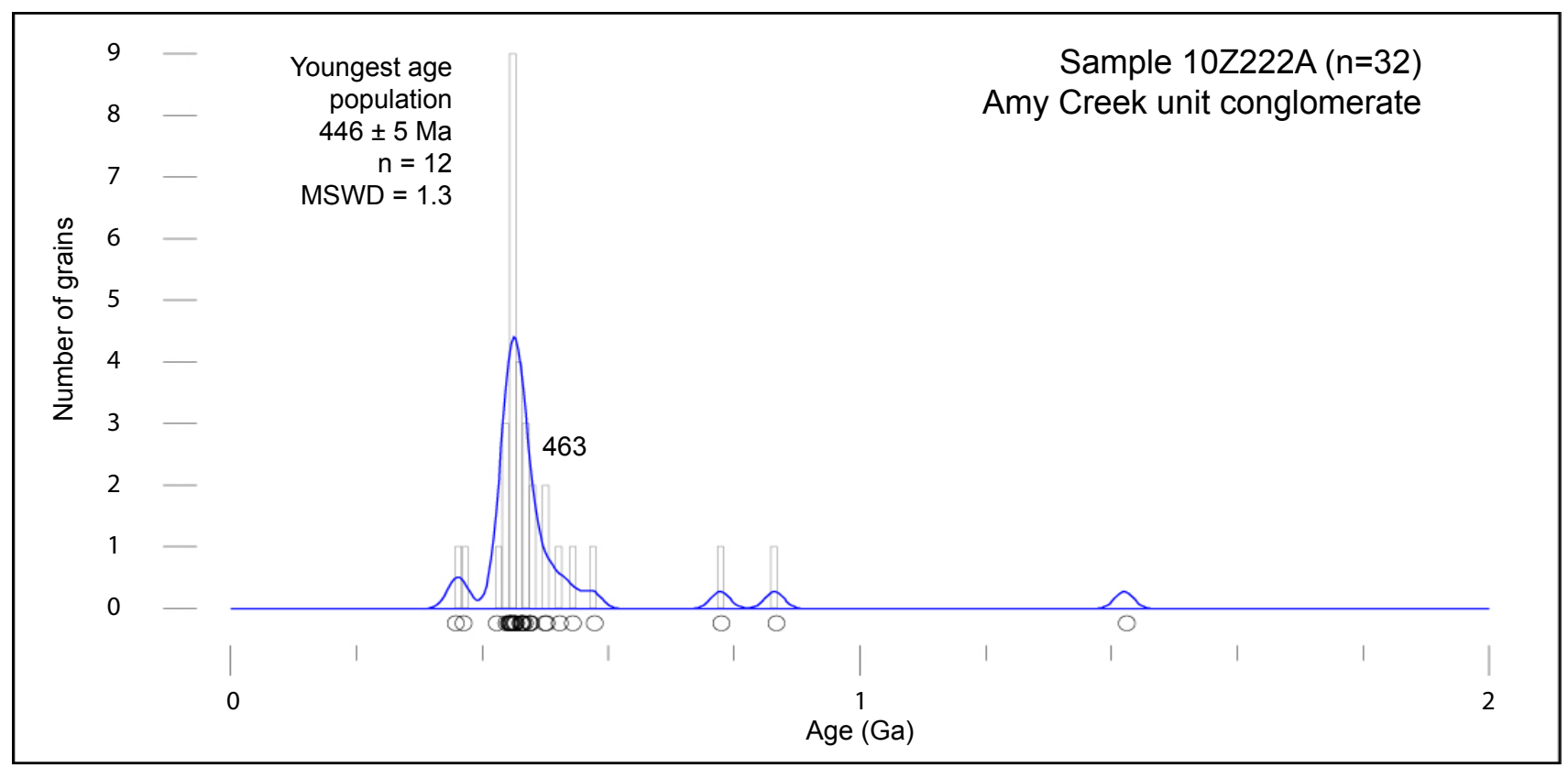

Figure C-1. Kernel Density Estimate (KDE) plot for sample 102222A. Age probability diagrams are kernel density estimates (KDEs) and were generated using the Density Plotter tool of Vermeesch (2012). The horizontal axis is age (in Ga), and the vertical axis is number of grains for the histogram. Histogram bins are all approximately 20 m.y.

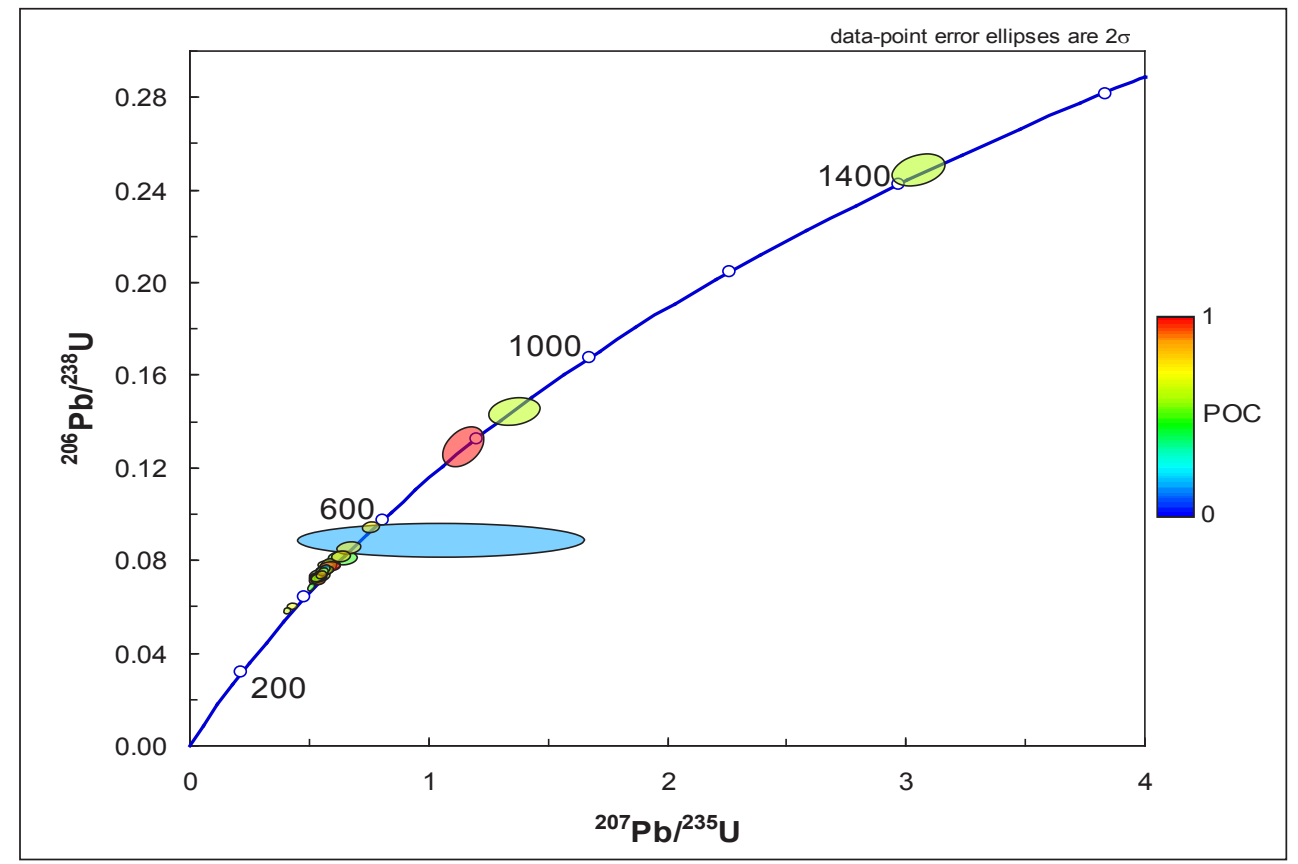

Figure C-2. U-Pb Concordia Diagram for all non-filtered data from sample 10Z222A. The ellipses are shaded by probability of concordance (POC) to illustrate the relationship between the calculated POC and concordia for each analysis. 


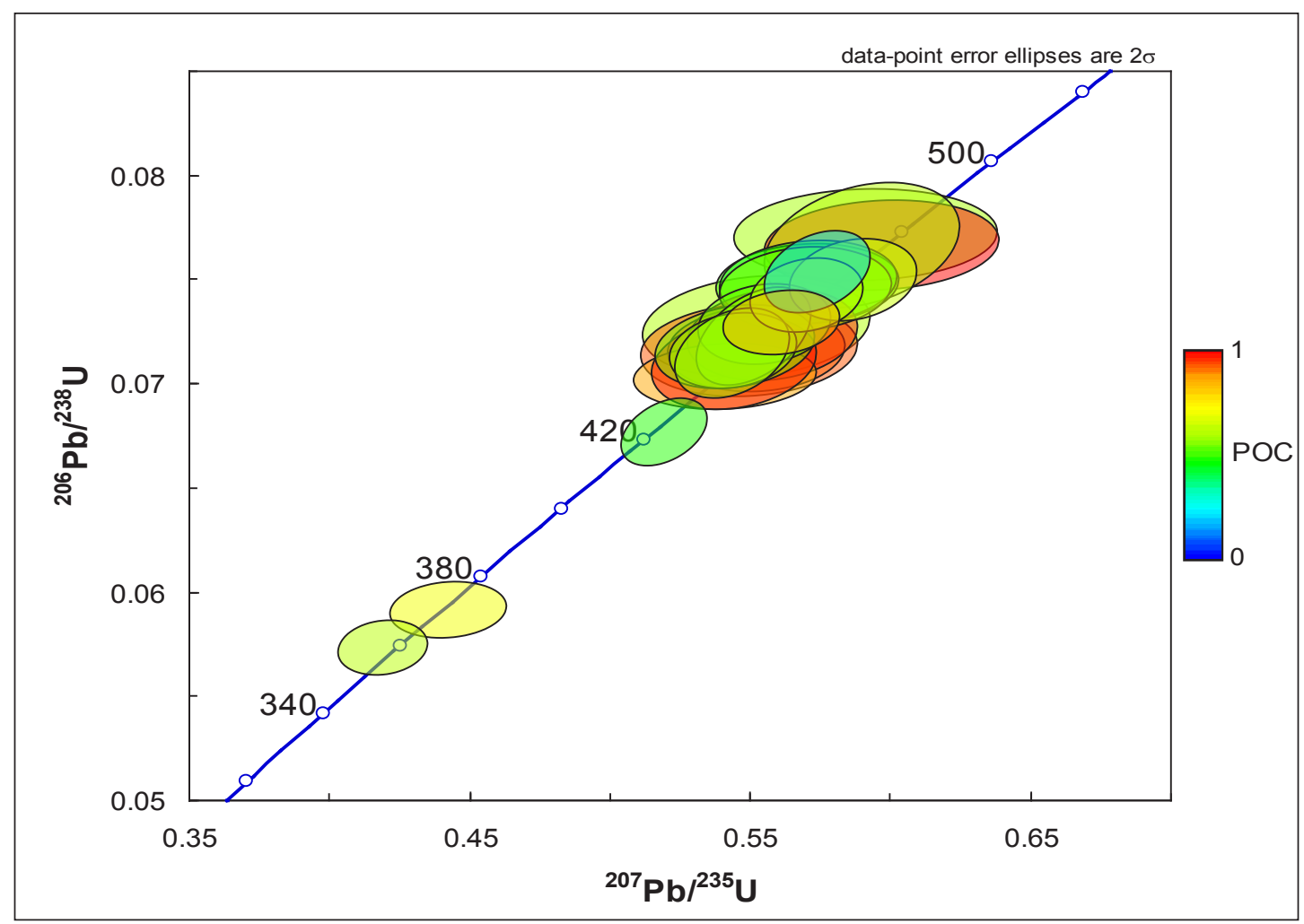

Figure C-3. U-Pb Concordia Diagram for youngest grains in sample 102222A only. The ellipses are shaded by probability of concordance (POC) to illustrate the relationship between the calculated POC and concordia for each analysis.

Table C-1. Detrital zircon age summary for sample $102222 \mathrm{~A}\left(65.53282^{\circ} \mathrm{N}, 148.62650^{\circ} \mathrm{W}, \mathrm{WGS} 84\right)$.

\begin{tabular}{|c|c|c|c|c|c|c|c|c|c|c|c|}
\hline \multirow[t]{2}{*}{$\mathbf{N}_{\text {total }}$} & \multirow{2}{*}{$\begin{array}{c}\text { Age } \\
\text { Range } \\
\text { (Ma) } \\
\end{array}$} & \multirow{2}{*}{$\begin{array}{l}\% p € \\
\text { grains }\end{array}$} & \multirow{2}{*}{$\begin{array}{c}\text { Min. age } \\
\text { pop. } \\
\text { (Ma) }\end{array}$} & \multirow{2}{*}{$\begin{array}{c} \pm \\
(2 \sigma)\end{array}$} & \multirow[t]{2}{*}{$N_{\text {min }}$} & \multirow[t]{2}{*}{$M W_{\min }$} & \multicolumn{2}{|c|}{$\begin{array}{c}\text { Peak age } \\
\text { range(s) (Ma) }\end{array}$} & \multirow[t]{2}{*}{ Nrange } & \multirow{2}{*}{$\begin{array}{c}\text { Peak } \\
\text { age } \\
\text { (Ma) }\end{array}$} & \multirow[t]{2}{*}{$N_{\text {peak }}$} \\
\hline & & & & & & & Min. & Max. & & & \\
\hline 39 & $1425-83$ & 3 & 446 & 5 & 12 & 1.3 & 435 & 486 & 21 & 446 & 11 \\
\hline & & & & & & & 509 & 513 & 0 & 463 & 8 \\
\hline
\end{tabular}


Table C-2. Summary of detrital zircon U-Pb analyses. The column labeled "Preferred age" is either the ${ }^{206} \mathrm{~Pb} /{ }^{238} \mathrm{U}$ or ${ }^{207} \mathrm{~Pb} / 206 \mathrm{~Pb}$ age. The calculated concordia age was used for age probability diagrams; note close agreement with Preferred age. Analyses shown in strikethrough were not used in age calculations and are not included in the plots because they did not meet the screening criteria described in the accompanying text. See digital data distribution package for additional parameters.

\begin{tabular}{|c|c|c|c|c|c|c|c|c|c|c|}
\hline $\begin{array}{l}\text { Analysis } \\
\text { Name }\end{array}$ & $\begin{array}{c}U \\
\text { (ppm) }\end{array}$ & $\begin{array}{c}\text { Th } \\
\text { (ppm) }\end{array}$ & $\begin{array}{l}{ }^{207} \mathrm{~Pb} / \\
{ }^{235} \mathrm{Uc}\end{array}$ & $\pm(2 \sigma)$ & $\begin{array}{c}{ }^{206} \mathrm{~Pb} / \\
{ }^{238} \mathrm{U}\end{array}$ & $\pm(2 \sigma)$ & $\begin{array}{l}\text { Preferred } \\
\text { Age (Ma) }\end{array}$ & $+(2 \sigma)$ & $\begin{array}{c}\text { Concordia } \\
\text { age (Ma) }\end{array}$ & $\pm(2 \sigma)$ \\
\hline 112307 _4 & 275 & 144 & 1.5404 & 0.0650 & 0.1484 & 0.0050 & $946.65^{1}$ & 26.15 & 921.26 & 21.79 \\
\hline 112307 28 & 374 & 271 & 0.3795 & 0.0204 & 0.0488 & 0.0014 & $307.40^{2}$ & 8.53 & 311.15 & 7.94 \\
\hline 112307 _1 & 1235 & 1162 & 0.5586 & 0.0211 & 0.0700 & 0.0021 & $435.97^{2}$ & 12.45 & 441.83 & 11.20 \\
\hline 112307_12 & 369 & 91 & 0.0875 & 0.0087 & 0.0129 & 0.0004 & $82.56^{2}$ & 2.60 & 82.77 & 2.52 \\
\hline 112307_38 & 151 & 74 & 0.1964 & 0.0187 & 0.0272 & 0.0008 & $173.05^{2}$ & 5.11 & 173.74 & 4.96 \\
\hline 112307_19 & 569 & 348 & 0.4199 & 0.0131 & 0.0572 & 0.0010 & $358.64^{2}$ & 6.40 & 357.87 & 5.62 \\
\hline 112307_29 & 428 & 146 & 0.4431 & 0.0169 & 0.0591 & 0.0011 & $370.02^{2}$ & 6.75 & 370.53 & 6.18 \\
\hline 112307_7 & 2093 & 2597 & 0.5197 & 0.0126 & 0.0676 & 0.0013 & $421.75^{2}$ & 8.00 & 423.20 & 6.86 \\
\hline 112307_27 & 179 & 86 & 0.5416 & 0.0265 & 0.0703 & 0.0013 & $438.00^{2}$ & 7.80 & 438.20 & 7.41 \\
\hline 112307_11 & 260 & 125 & 0.5448 & 0.0240 & 0.0709 & 0.0018 & $441.73^{2}$ & 11.09 & 441.69 & 9.92 \\
\hline 112307_31 & 651 & 253 & 0.5440 & 0.0165 & 0.0714 & 0.0018 & $444.60^{2}$ & 10.63 & 442.88 & 8.73 \\
\hline 112307_30 & 329 & 213 & 0.5443 & 0.0184 & 0.0715 & 0.0015 & $445.12^{2}$ & 8.99 & 443.89 & 7.86 \\
\hline 112307_37 & 320 & 117 & 0.5451 & 0.0233 & 0.0717 & 0.0017 & $446.66^{2}$ & 9.94 & 445.47 & 9.11 \\
\hline 112307_26 & 98 & 28 & 0.5499 & 0.0314 & 0.0716 & 0.0018 & $445.79^{2}$ & 11.00 & 445.62 & 10.17 \\
\hline 112307_6 & 138 & 69 & 0.5526 & 0.0260 & 0.0716 & 0.0017 & $445.86^{2}$ & 10.01 & 446.06 & 8.92 \\
\hline 112307_15 & 2322 & 1242 & 0.5517 & 0.0166 & 0.0722 & 0.0019 & $446.12^{1}$ & 10.92 & 447.64 & 9.51 \\
\hline 112307_17 & 216 & 79 & 0.5583 & 0.0248 & 0.0723 & 0.0018 & $450.10^{2}$ & 10.83 & 450.19 & 9.65 \\
\hline 112307_9 & 115 & 39 & 0.5523 & 0.0330 & 0.0727 & 0.0020 & $452.45^{2}$ & 12.16 & 451.28 & 11.29 \\
\hline 112307_23 & 423 & 186 & 0.5553 & 0.0192 & 0.0728 & 0.0016 & $452.94^{2}$ & 9.54 & 451.40 & 8.13 \\
\hline 112307_22 & 622 & 506 & 0.5613 & 0.0168 & 0.0729 & 0.0013 & $453.50^{2}$ & 7.77 & 453.14 & 6.81 \\
\hline 112307_14 & 607 & 250 & 0.5704 & 0.0164 & 0.0742 & 0.0015 & $461.40^{2}$ & 8.81 & 460.19 & 7.38 \\
\hline 112307_25 & 263 & 148 & 0.5698 & 0.0251 & 0.0745 & 0.0016 & $463.18^{2}$ & 9.76 & 461.90 & 8.76 \\
\hline 112307_20 & 190 & 99 & 0.5706 & 0.0265 & 0.0747 & 0.0016 & $464.67^{2}$ & 9.49 & 463.34 & 8.63 \\
\hline 112307_39 & 201 & 106 & 0.5709 & 0.0257 & 0.0748 & 0.0017 & $465.11^{2}$ & 9.98 & 463.57 & 9.01 \\
\hline 112307_2 & 1839 & 2532 & 0.5745 & 0.0153 & 0.0753 & 0.0016 & $468.11^{2}$ & 9.59 & 464.64 & 7.97 \\
\hline 112307_34 & 667 & 262 & 0.5869 & 0.0185 & 0.0749 & 0.0016 & $465.78^{2}$ & 9.68 & 466.95 & 8.21 \\
\hline 112307_16 & 223 & 67 & 0.5901 & 0.0281 & 0.0766 & 0.0024 & $475.83^{2}$ & 14.65 & 474.05 & 12.83 \\
\hline 112307_36 & 155 & 97 & 0.5975 & 0.0340 & 0.0766 & 0.0018 & $475.69^{2}$ & 10.49 & 475.68 & 9.84 \\
\hline 112307_5 & 86 & 34 & 0.5914 & 0.0380 & 0.0771 & 0.0018 & $478.80^{2}$ & 10.74 & 477.74 & 10.04 \\
\hline 112307_32 & 76 & 31 & 0.6498 & 0.0486 & 0.0801 & 0.0023 & $496.83^{2}$ & 14.01 & 498.64 & 13.06 \\
\hline 112307_35 & 160 & 113 & 0.6419 & 0.0315 & 0.0808 & 0.0020 & $500.84^{2}$ & 11.80 & 501.46 & 10.74 \\
\hline 112307_3 & 86 & 35 & 0.6792 & 0.0399 & 0.0844 & 0.0024 & $522.20^{2}$ & 14.21 & 523.00 & 13.33 \\
\hline 112307_21 & 48 & 13 & 1.0609 & 0.4902 & 0.0875 & 0.0059 & $540.92^{2}$ & 35.02 & 543.60 & 34.77 \\
\hline 112307_18 & 230 & 223 & 0.7707 & 0.0300 & 0.0937 & 0.0017 & $577.26^{2}$ & 10.10 & 577.91 & 9.23 \\
\hline 112307_8 & 209 & 141 & 1.1553 & 0.0712 & 0.1286 & 0.0070 & $779.74^{1}$ & 33.84 & 779.78 & 30.14 \\
\hline 112307_13 & 47 & 72 & 1.3686 & 0.0906 & 0.1436 & 0.0049 & $864.94^{2}$ & 27.39 & 867.94 & 24.62 \\
\hline 112307_24 & 125 & 41 & 3.0559 & 0.0924 & 0.2483 & 0.0055 & $1421.70^{1}$ & 23.26 & 1424.49 & 20.57 \\
\hline 112307 10 & 4258 & 2297 & 0.0000 & 0.0000 & 0.0000 & 0.0000 & $89.93^{3}$ & 25.24 & $\mathrm{n} / \mathrm{a}$ & $\mathrm{n} / \mathrm{a}$ \\
\hline 112307 33 & 513 & 231 & 0.0000 & 0.0000 & 0.0000 & 0.0000 & $812.61^{3}$ & 89.81 & $\mathrm{n} / \mathrm{a}$ & $\mathrm{n} / \mathrm{a}$ \\
\hline
\end{tabular}

${ }^{1207} \mathrm{~Pb} / 235 \mathrm{Uc}$ concordant scans

${ }^{2206} \mathrm{~Pb} / 238 \mathrm{U}$ concordant scans

${ }^{3} \mathrm{Pbc}$-corrected isotopic sums 
Table C-3. Zircon standards used in calibration.

\begin{tabular}{|c|l|l|l|}
\hline Standard & \multicolumn{1}{|c|}{ Standard } & \multicolumn{1}{c|}{ U-Pb age ( $\mathbf{1 2} \sigma)$} & \multicolumn{1}{c|}{ Reference } \\
\hline FC & Duluth complex & $1,099.0 \pm 0.6 \mathrm{Ma}$ & Paces and Miller, 1993 \\
\hline F5 & Duluth complex & $\begin{array}{l}1,099.0 \pm 0.6 \mathrm{Ma} \text { (assumed } \\
\text { equal to FC-1) }\end{array}$ & Paces and Miller, 1993 \\
\hline IF & Fish Canyon Tuff & $28.201 \pm 0.012 \mathrm{Ma}$ & $\begin{array}{l}\text { Lanphere and Baadsraard, 2001; Kuiper and } \\
\text { others, 2008 }\end{array}$ \\
\hline MD & Mount Dromedary & $99.12 \pm 0.14 \mathrm{Ma}$ & Renne and others, 1998 \\
\hline PX & Peixe & $563.5 \pm 1.6 \mathrm{Ma}$ & Gehrels and others, 2008 \\
\hline R3 & Braintree complex & $418.9 \pm 0.4 \mathrm{Ma}$ & Black and others, 2004 \\
\hline T2 & $\begin{array}{l}\text { Temora 2, Middledale } \\
\text { gabbroic diorite }\end{array}$ & $416.78 \pm 0.33 \mathrm{Ma}$ & Black and others, 2004 \\
\hline TR & Tardree Rhyolite & $61.23 \pm 0.11 \mathrm{Ma}$ & Dave Chew, personal communication \\
\hline
\end{tabular}

